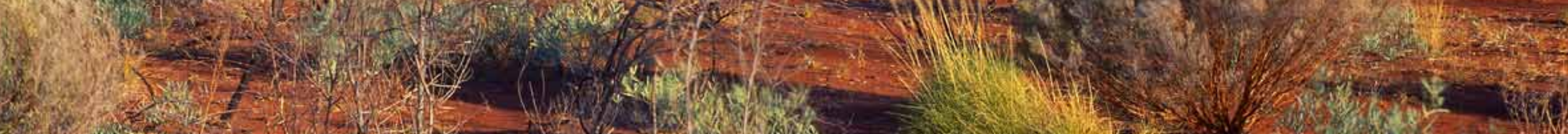

H.t.

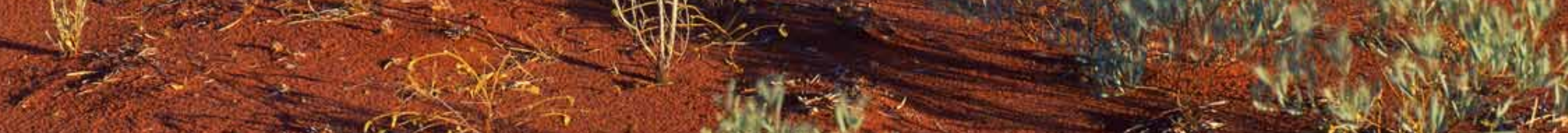
(1)

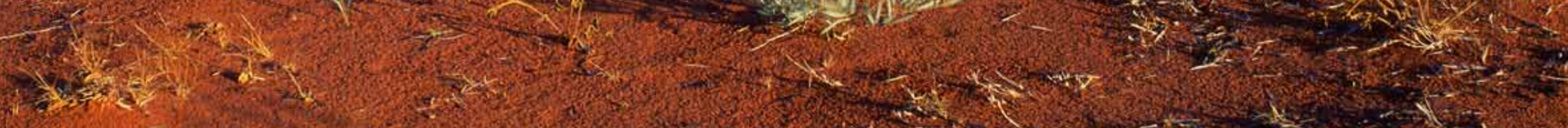




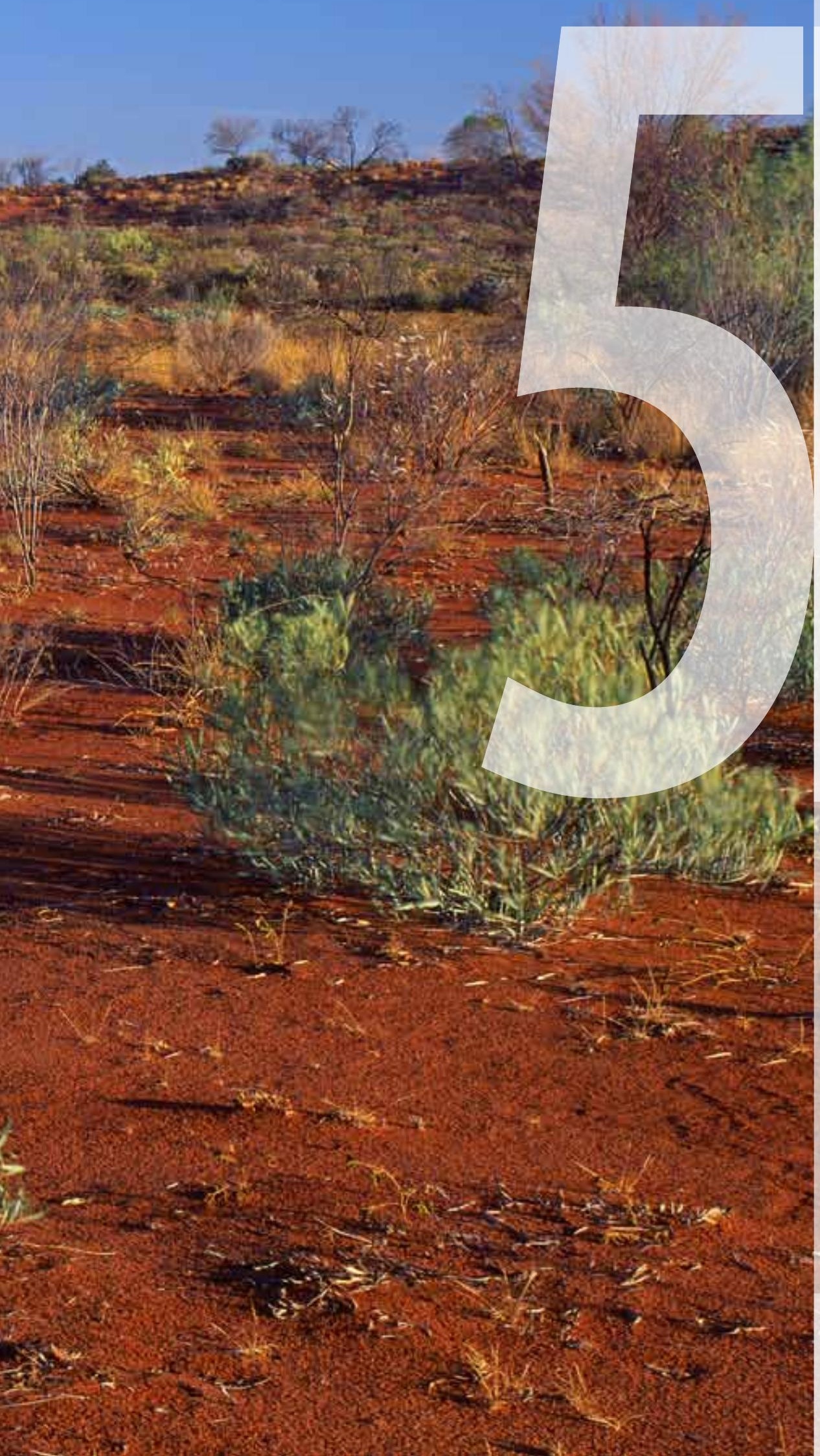

\section{Old, flat and red-Australia's distinctive landscape}

Most of Australia's landscape is stark, and the climate is harsh. The landscape is also remarkably flat, with an average elevation of only about $325 \mathrm{~m}$ and local relief never more than $1500 \mathrm{~m}$. As a result, many of Australia's major rivers are slow flowing, commonly into salt lakes in the arid interior. A thick regolith also blankets much of the continent. Sustained weathering has resulted in the formation of abundant iron oxides in the regolith, giving the Australian landscape its distinctive red colour. The regolith holds great wealth for Australia, but can also present challenges for mineral exploration. Human occupation over the past 50000 years, and especially the last 200 years, has left a significant mark on the landscape.

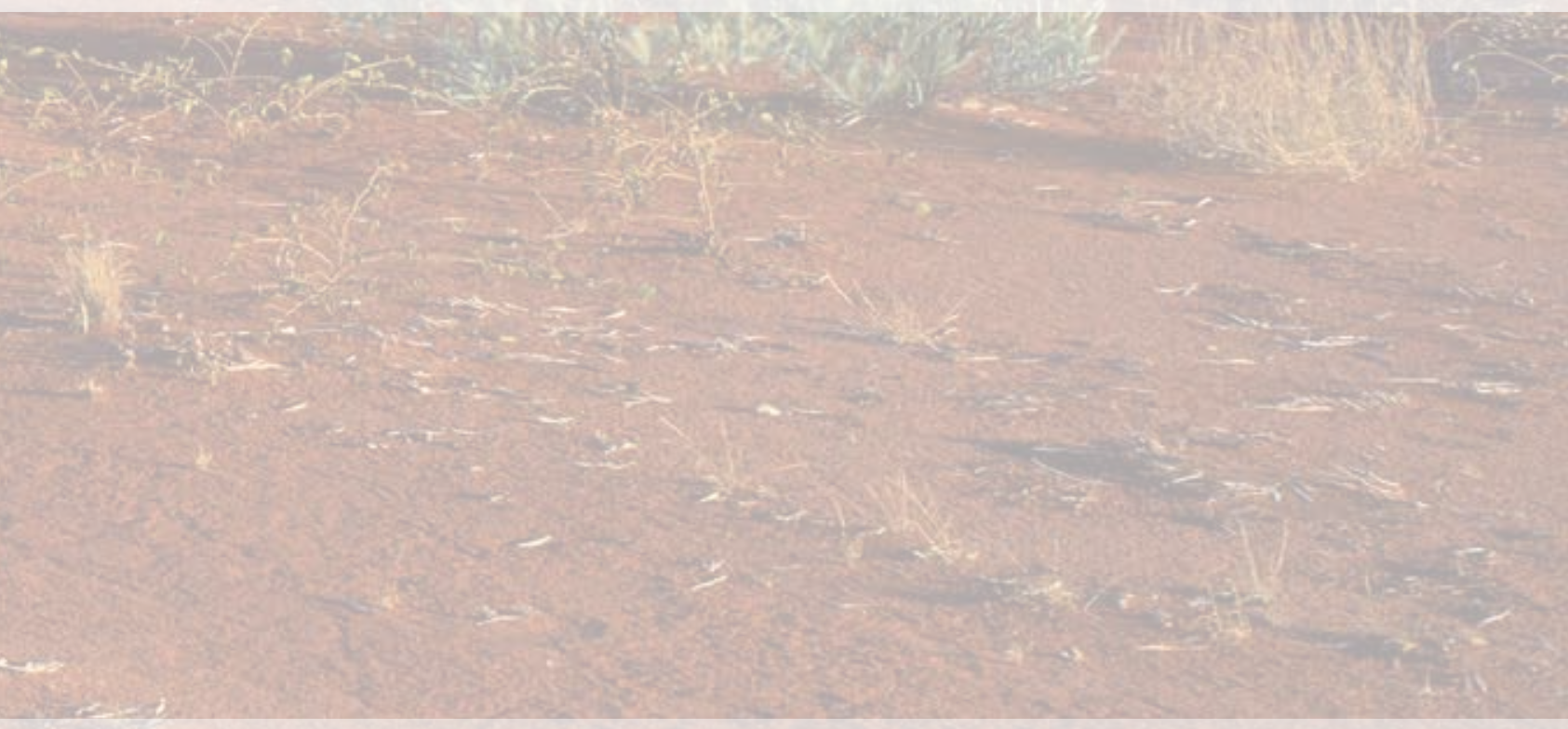

Colin F Pain, ${ }^{1,3}$ Brad J Pillans, ${ }^{2}$ Ian C Roach, ${ }^{3}$ Lisa Worrall ${ }^{4,3}$ and John $R$ Wilford ${ }^{3}$

'University of Seville, ${ }^{2}$ Australian National University, ${ }^{3}$ Geoscience Australia, ${ }^{4}$ Zeus Uranium Ltd Image by Mark Gray 


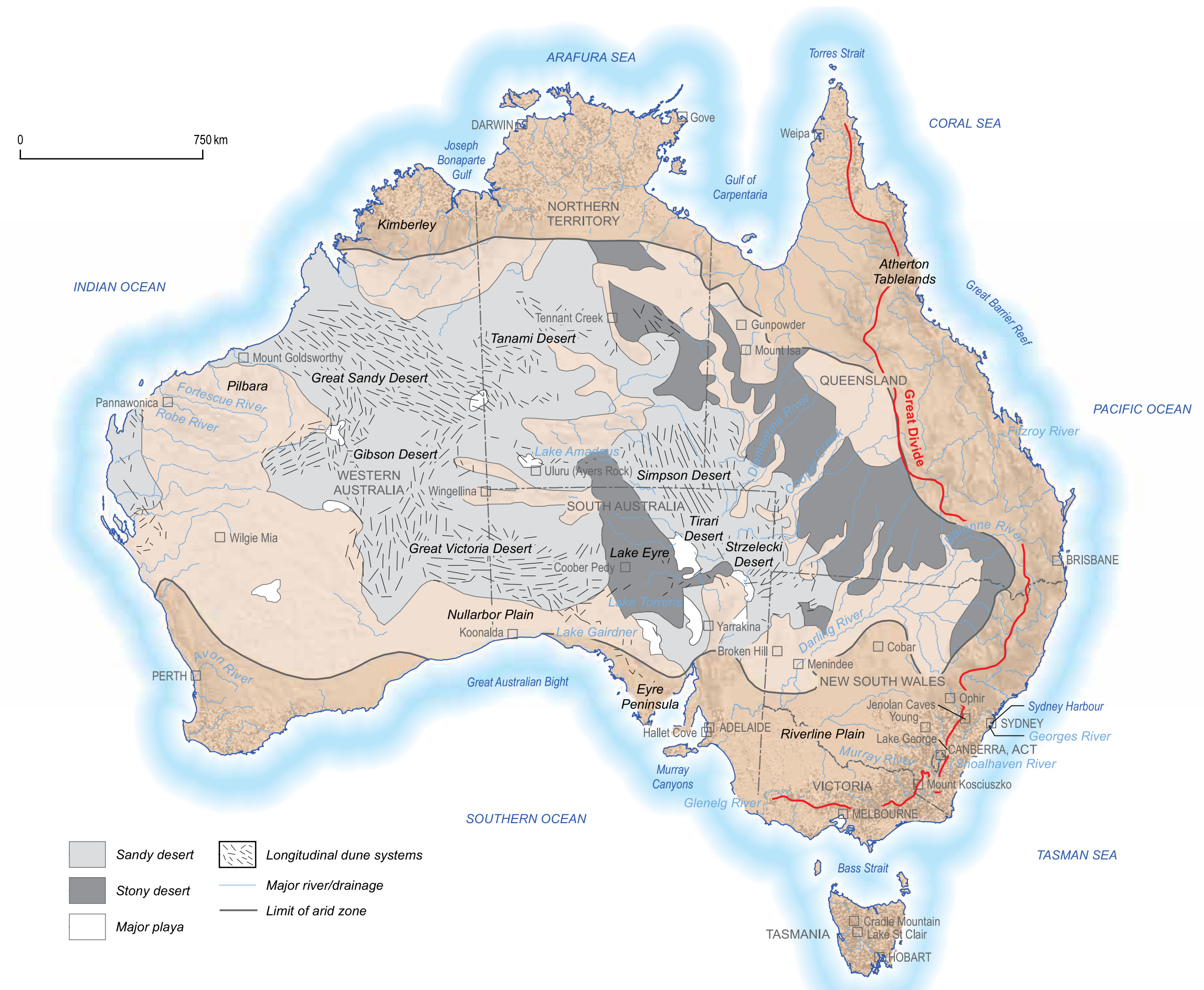

Figure 5.1: Locality and features map, also showing Australia's deserts, rivers and lakes. 


\section{Regolith}

The Australian landscape is remarkably flat, and around $80 \%$ is covered by a thick, and in places ancient, blanket of red-coloured regolith (Figure 5.1, Box 5.1). The regolith forms as a result of the interaction between rocks, water, air and life (Figure 5.2a), which drive processes operating at or near the surface, such as weathering, erosion, transportation, sedimentation and cementation (Figure 5.2b). Regolith can be thought of as everything between fresh rock and fresh air; it is somewhat synonymous with what has been called the 'critical zone'. Regolith dictates the nature of the Australian landscape, and has had a profound effect on the development of Australia and the way people have lived, and continue to live, on the continent.

Regolith may vary in thickness from a few centimetres to hundreds of metres and can have a complex architecture. Components of the regolith range in age from very young-for example, sediments deposited by a recent flood (Figure 5.3a) - to very old-for example, PermoCarboniferous oxidation of iron in weathering profiles exposed by mining in the Tanami region of the Northern Territory (Figure 5.3b). The fact that ancient landscapes have been preserved is linked to the overall tectonic stability of the continent. This stability and landscape longevity have resulted in a continent that is deeply weathered and soils that are nutritionally poor and fragile.

Geography and plate position are driven by tectonics. After the breakup of PangaeaGondwana, Australia drifted northwards through the Cenozoic into a geographical position that has made it the most arid inhabited continent.
The aridity, combined with the flatness of the landscape, has created river systems that are slow flowing. The slow-moving rivers, many draining into the interior, have struggled unsuccessfully to remove the wind-blown salt from the continent. As a result, the nutritionally poor soils are also prone to salinisation.

The soils and landscape differ markedly between Australia and much of the Northern Hemisphere. A key determinant of these differences was the role (or lack) of glaciers. The glaciers of the last ice ages transformed the Northern Hemisphere's landscape and soils, but the ice was restricted to small upland areas in southeastern Australia. This lack of glacial reworking and regeneration of soil and landscape in Australia was due to the low overall elevation and the latitudinal position of the continent at the time (Chapter 2).

Australia's landscape and regolith have been key determining factors in shaping where and how Australian people live. The regolith underpins our economic, social and infrastructure systems; we live on it, we grow our food in it, it is the foundation of many major engineering works, and much of our water supply is stored in it (Chapter 7). Regolith also hosts or hides valuable mineral deposits, and mineral exploration through and within the regolith is one of the greatest challenges facing mineral explorers in Australia in the 21st century (Chapter 11).

The richness and diversity of Australia's regolith makes a fascinating story, so let us first look back to how the continent's landscape and climate were transformed after the continent was finally released 'out of Gondwana' (Chapter 4).
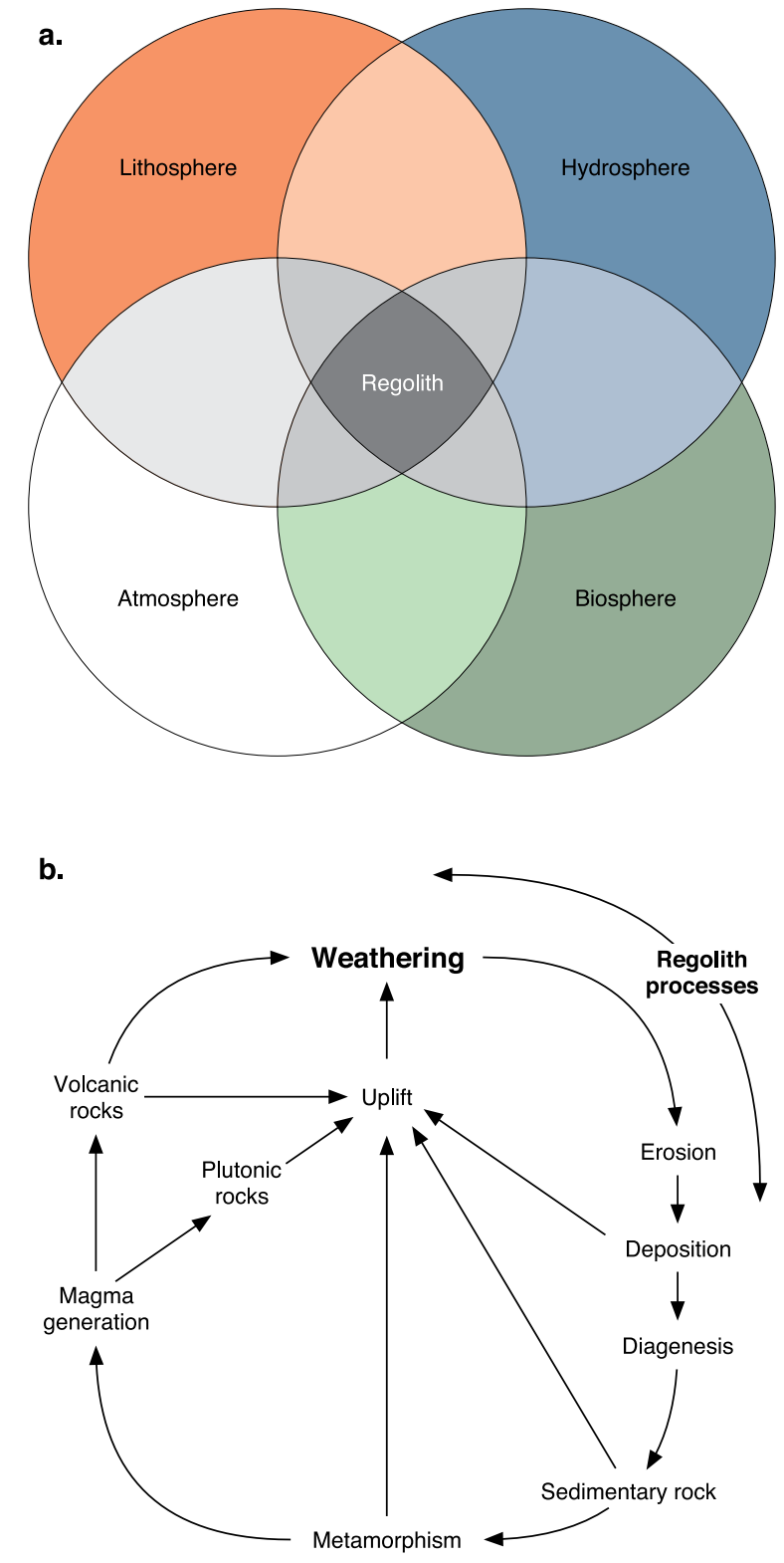

Figure 5.2: (a) The regolith is the critical interface between four of Earth's spheres: the lithosphere, hydrosphere, biosphere and atmosphere. (Source: Taylor \& Eggleton, 2001). (b) Role of regolith processes in the geological rock cycle. (Source: Wilson, 2004) 

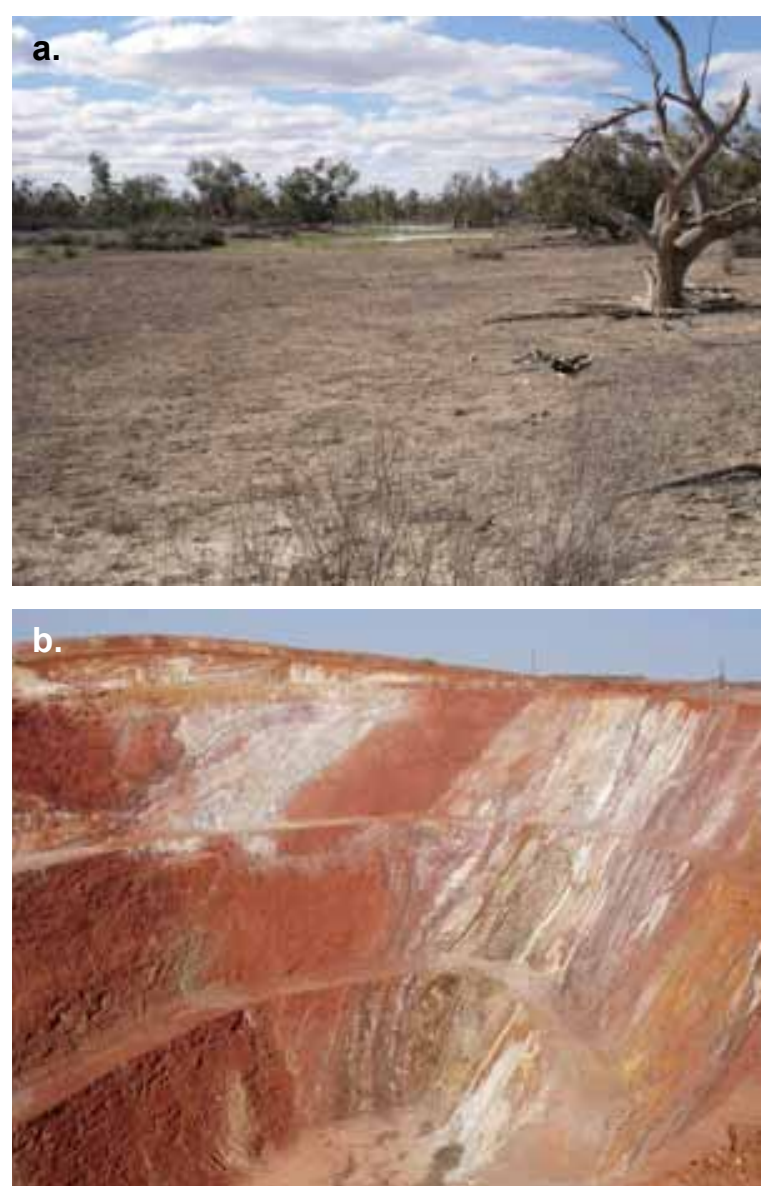

Figure 5.3: (a) Sediments deposited by recent floods on the Darling River Floodplain near Menindee, western New South Wales. (b) Weathering profile (more than $30 \mathrm{~m}$ deep) exposed in the wall of an openpit gold mine, Tanami region, Northern Territory.

\section{Cenozoic climate changes of the Australian landscape}

Australia is the second driest continent in the world, Antarctica being the driest. There is ample evidence of dramatically different climates in the past compared with the present (Chapter 3), with the strongest imprint on the landscape occurring during the Cenozoic. The period from $65 \mathrm{Ma}$ to about $35 \mathrm{Ma}$ (broadly equivalent to the Paleocene and Eocene epochs) saw a significantly warmer world, with no Antarctic ice sheet, sea-levels perhaps some $60 \mathrm{~m}$ higher than present and atmospheric $\mathrm{CO}_{2}$ concentrations more than three times that of modern levels. During that time, the Australian continent lay well to the south of its current position, and the dominant vegetation was warm to cool temperate rainforest, even in central Australia (Chapter 2).

From about $35 \mathrm{Ma}$ (latest Eocene), the Antarctic ice sheet progressively increased in size, global temperatures decreased, sea-levels fell, and central Australia became progressively more arid as the Australian continent moved northwards to straddle the zone of subtropical high pressure that is characterised by mid-latitude deserts on both sides of the equator. Pollen evidence suggests that seasonal aridity may have been the norm in parts of central Australia as early as $40 \mathrm{Ma}$ (middle Eocene).

Nevertheless, around $30 \mathrm{Ma}$ the moisture-loving ancestors of Wollemi pines and southern beech trees were growing in the now semi-arid Pilbara in Western Australia, and around $25 \mathrm{Ma}$ large central Australian freshwater lakes, forerunners to Lake Eyre, had formed, inhabited by crocodiles, dolphins and giant flamingos. Indeed, fully desert conditions were probably not established until around $3 \mathrm{Ma}$ (Late Pliocene). For example, from cosmogenic ${ }^{21} \mathrm{Ne}$ and ${ }^{10} \mathrm{Be}$ dating, it is clear that stony deserts in northern South Australia formed at 2-4 Ma, while major dunes formed somewhat later, from around $1 \mathrm{Ma}$ (Figure 5.4).

With the increase in Antarctic ice, subtropical high-pressure systems moved from the south to dominate the continental interior (Figure 5.5). One outcome of this increased aridity was that some rivers draining to the south were unable to adjust their gradients to the post-Miocene tectonics, especially on a continental scale to the northeast, and became disorganised or moribund with a number of swampy lakes adjacent to the tilt axis. These lakes contracted and disappeared, with marked faunal changes as the land dried up (Chapter 3).

The cooling of Earth's climate during the Quaternary glaciations, starting about 2.6 Ma, led to wetter and drier cycles related to glacial and interglacial periods, and concomitant fluctuation in the amount of water flowing into the interior. During the cold, dry glacial periods, aeolian landforms (dunes) spread out from central Australia and moved into surrounding areas, where they can still be seen today as more or less stable. Australia does not have as wide a variety of dune forms as the Sahara Desert, but the dunes can be dramatic; most are longitudinal, some tens of kilometres in length. The pattern of dune fields mirrors the anticlockwise pattern of the dominant winds in Australia (Figure 5.5). 
In a word, the answer is hematite (from the Greek haimatites, meaning bloodlike). This iron oxide $\left(\mathrm{Fe}_{2} \mathrm{O}_{3}\right)$ is formed by weathering and is largely responsible for the pervasive red colour of rocks, soils, dust and sand that characterise central Australian landscapes. Every visitor knows how a combination of red dust and sweat produces stains on clothes that are almost impossible to remove. Hematite is also the predominant pigment in red ochre, one of the clays favoured by Aboriginal artists for their paintings.

The iconic Red Centre of Australia is broadly encompassed by the $500 \mathrm{~mm}$ mean annual rainfall isohyet, suggesting that redness is related to aridity-which is certainly true. Aridity came rather late to central Australia, geologically speaking, probably beginning in mid-Cenozoic times as the Australian Plate moved northwards to straddle the dry mid-latitudes, and progressively intensified during the last 2-3 Myr. However, much of the red colour in the rocks originated prior to the last $3 \mathrm{Myr}$, at times when the climate was significantly wetter than the presentfor example, between $80 \mathrm{Ma}$ and $60 \mathrm{Ma}$. Furthermore, the red colour is not just a surface feature; it commonly extends to depths of more than $50 \mathrm{~m}$, as seen in openpit mine exposures throughout Australia (Figure 5.3b). On the other hand, the red sand dunes are much younger, mostly less than $1 \mathrm{Ma}$ according to luminescence and cosmogenic nuclide dating. The sand dunes are composed mostly of white quartz grains, but a thin coating of hematitic clay gives the reddest dunes their distinctive colour. Thus the Red Centre has a complex history of redness.

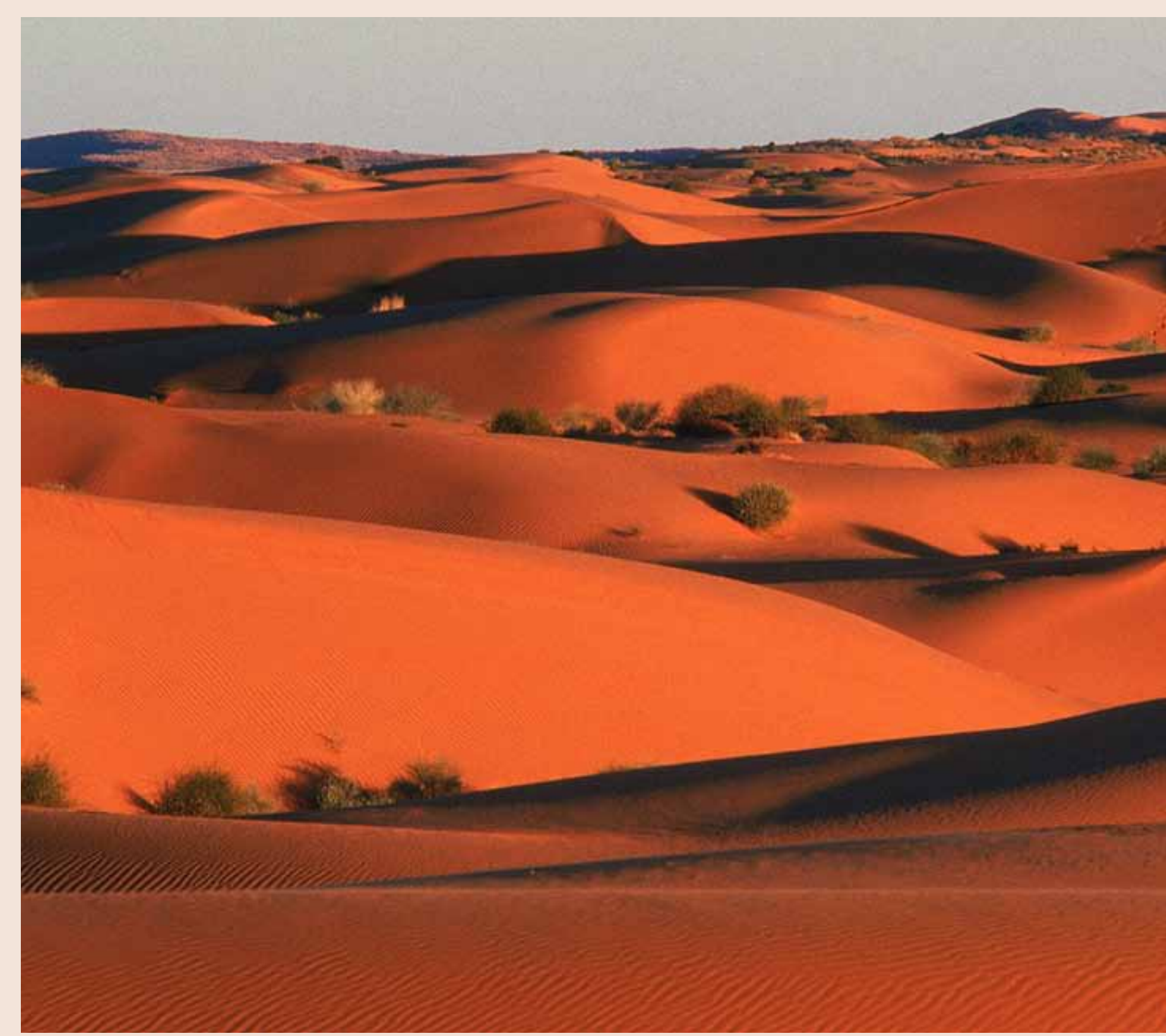

Images [T Mead]

Red sand dunes in the Sturt Desert, South Australia. 


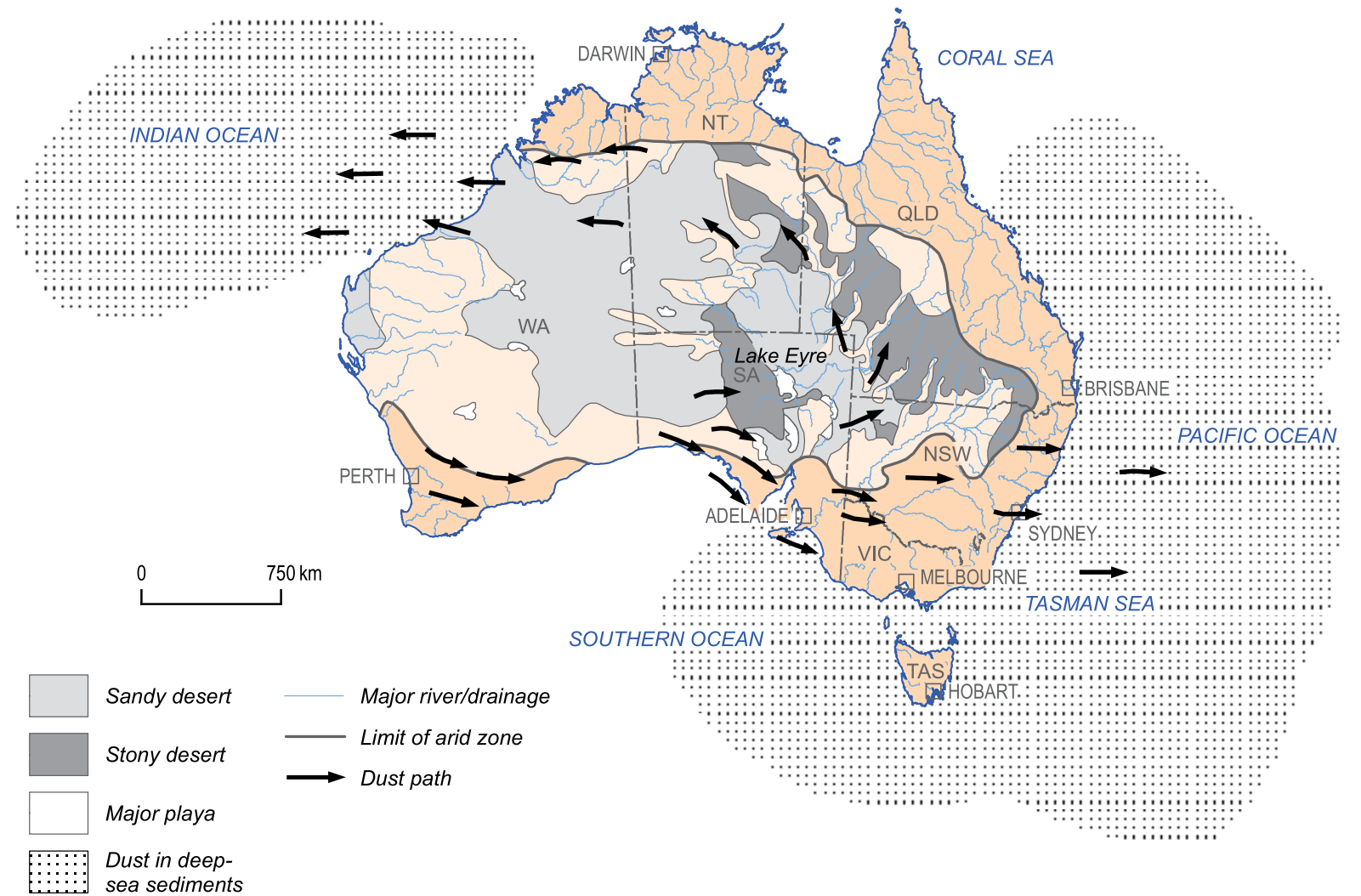

Figure 5.4: Major desert and dune systems of Australia. Note rivers and river catchments overlain by longitudinal dune systems and the distribution of stony and sandy deserts. (Sources: Bowler, 1976; Fujioka \& Chappell, 2010)
Winds also reach out from Australia from the northwest and southeast corners, carrying dust with them (Figure 5.4). Dust particles represent a link between the lithosphere, hydrosphere, atmosphere and biosphere (Figure 5.2a); they are therefore an important parameter in understanding climate. The analysis of dust can be used to better understand the El Niño/La Niña - Southern Oscillation (ENSO) climate system, as well as past shifts of the intertropical convergence zone on glacial-interglacial time scales (Chapter 1).

Because Australia does not have the nutrient-rich cold upwelling currents of other continents (Chapter 6), dust, and the iron carried with it from the continental interior, forms a vital part of the ocean's food web by partly regulating plankton growth. Today, around 4-7 Mt/year of Australian dust is deposited in the southwest Pacific Ocean, much via episodic dust-storm events. Australia contrasts with the other Southern Hemisphere dust sources (southern Africa: $60 \mathrm{Mt} /$ year; Patagonia: $30 \mathrm{Mt} / \mathrm{year}$ ) in that the dust amounts are less and they are very episodic. The reasons for these differences are undoubtedly related to the complex geology and regolith and the relatively higher amounts of vegetation in Australia's arid zone compared with other dust-source regions.

During the last glacial maximum, the continent was even more arid than today-it was also much windier, and dust was transported and deposited over vast distances. The dust may have enhanced marine productivity, drawing down atmospheric $\mathrm{CO}_{2}$ and further lowering temperatures at that time. Accumulations of dust both in the eastern highlands and in marine cores off the east coast of Australia coincide with dry climate periods. 
Recent work on the age of zircon grains from dust in eastern Australia shows that much of it was sourced from the Queensland highlands. Particles are transported down rivers into the interior, becoming finer as they go. Dust is then blown out of dry river and lake beds and makes its way in a step-like manner via winds back to the east (atmosphere). Because of the long history of particle recycling, the elemental composition of Australian dust tends to be different from that of dust from other continents. Australian dusts tend to be low in phosphorus and nitrogen, essential elements in ocean fertilisation. Interestingly, the iron in the Northern Hemisphere dust (Sahara Desert) interacts with that hemisphere's pollution (NOx, SOx), somewhat ironically making the iron more bioavailable for plankton growth in the Atlantic Ocean. The more pristine air masses (atmosphere) around Australia mean that the dust does not 'benefit' from this pollution, although workers suspect that the interaction with bushfire smoke may fulfil this role in part.

An obvious positive consequence of the dust is the accumulation of deep, red, loamy soils that are a valuable agricultural resource on the western slopes of New South Wales (Figure 5.6). Another obvious, but less positive, consequence is the large dust storms that sweep across southeastern Australia, particularly during times of drought. A dust storm in October 2002 eroded an estimated $96 \mathrm{Mt}$ of top soil and entrained around $5 \mathrm{Mt}$ of dust along a $2400 \mathrm{~km}$-long front in eastern Australia. Similarly, in September 2009 a huge dust plume crossed New South Wales and southeast Queensland, turning Sydney into a surreal, sunless, red city (Figure 5.7).
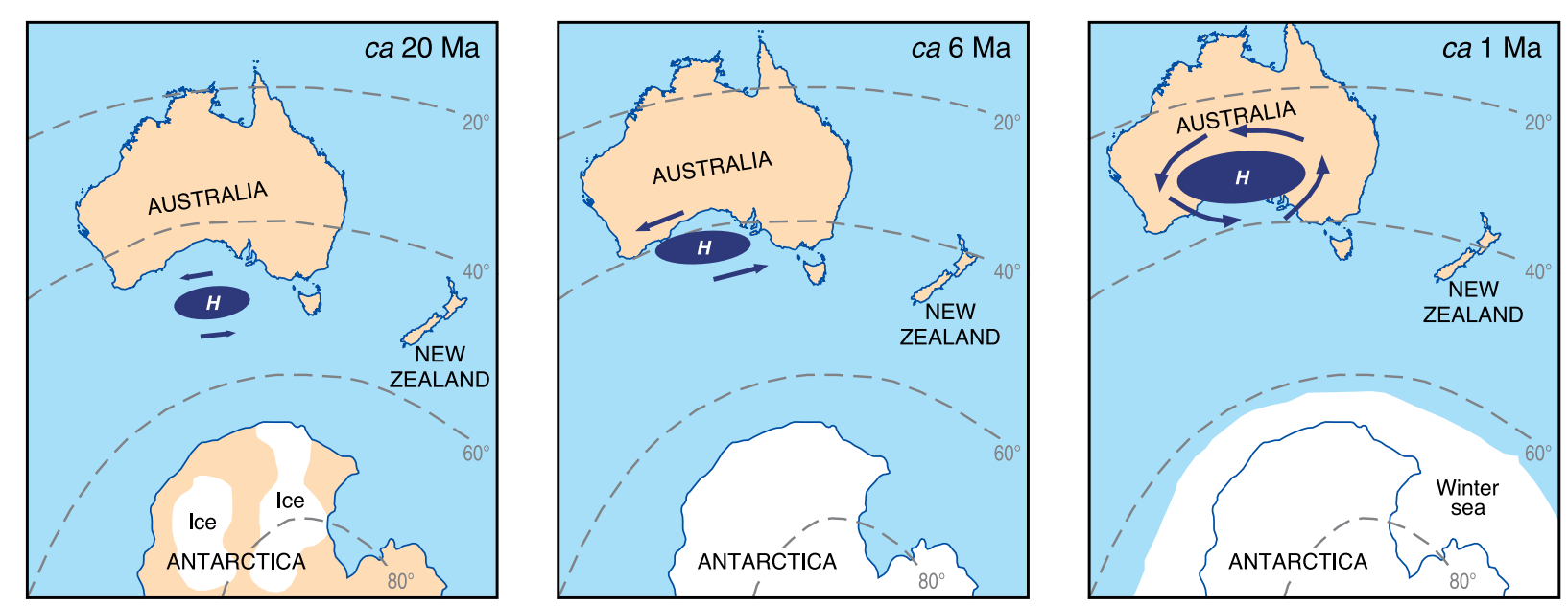

Figure 5.5: Factors influencing climatic changes of the last $20 \mathrm{Ma}, 6 \mathrm{Ma}$ and $1 \mathrm{Ma}$ in the Australia-Antarctic region. Note the increase in ice cover in Antarctica, and the move of the high-pressure system into the centre of the continent. (Source: Fujioka \& Chappell, 2010)

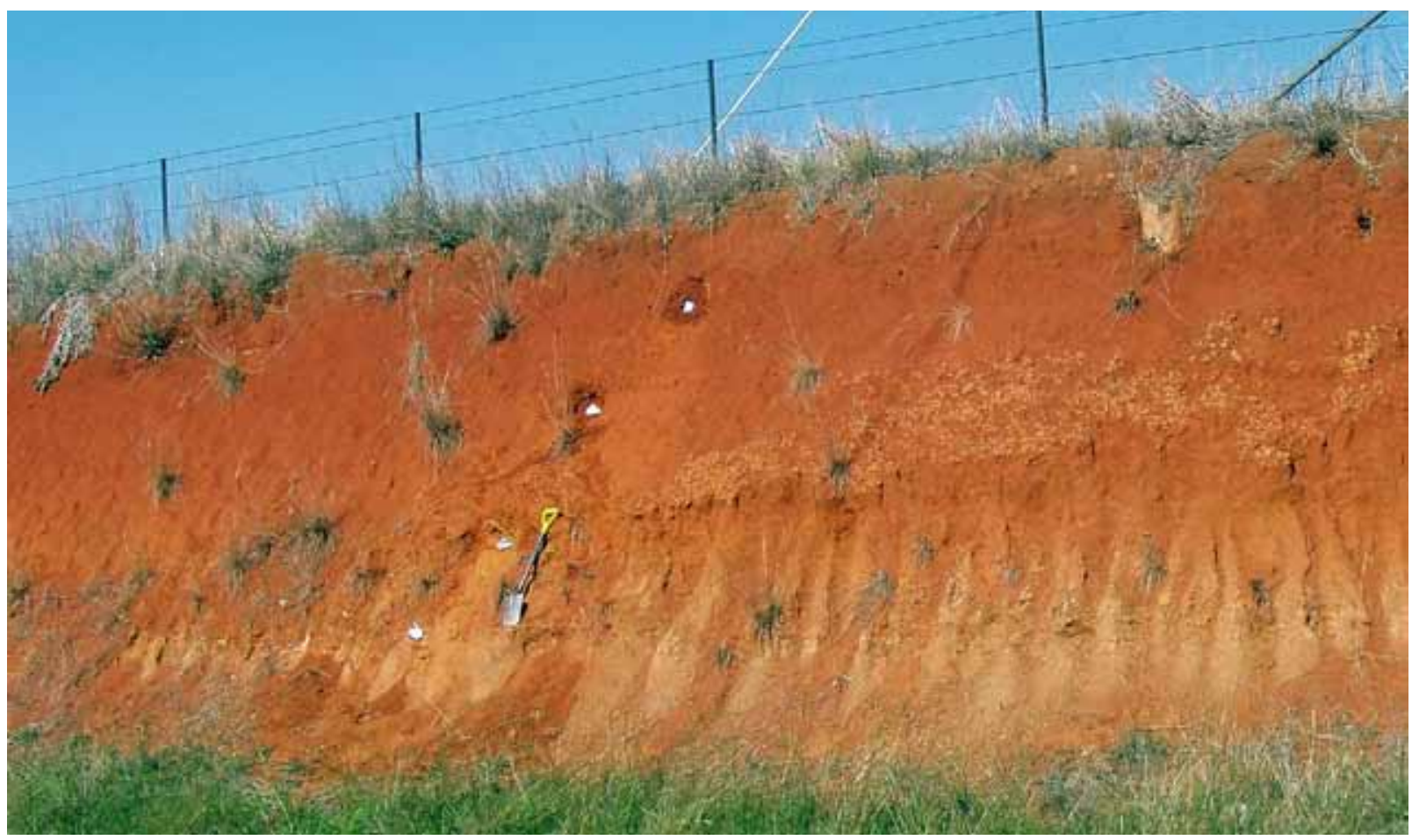

Figure 5.6: Deep loamy soils near Young, New South Wales. Young is the Australian capital of cherries, which are grown in these dust-derived soils. The region also prides itself on other stone fruits and fine wines. Originally named Lambing Flat, Young also featured in the early gold rushes (Chapter 8). A riot occurred there in 1861, with mainly European miners attacking Chinese miners, which resulted in curbs on immigration to the colony. 

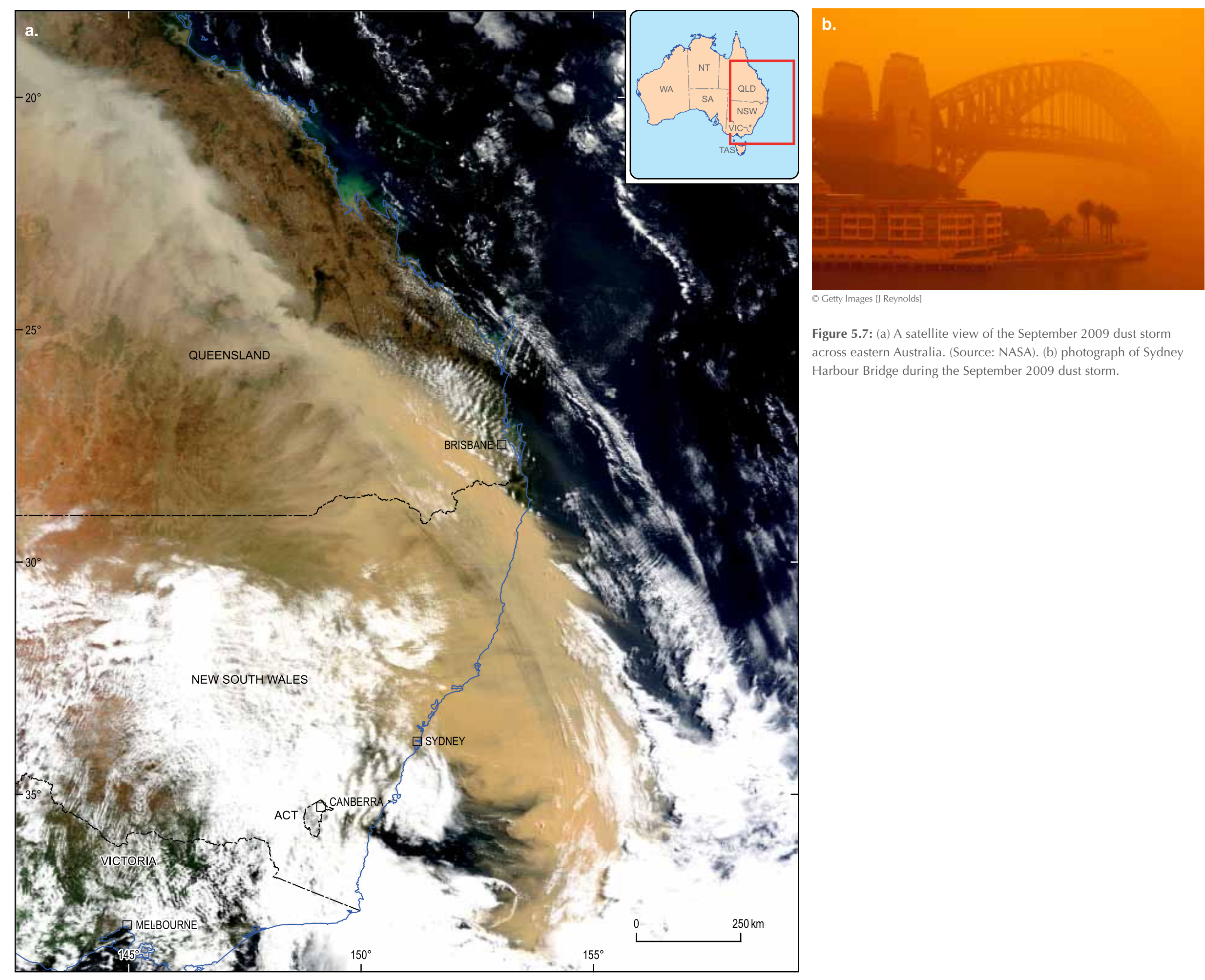

Figure 5.7: (a) A satellite view of the September 2009 dust storm across eastern Australia. (Source: NASA). (b) photograph of Sydney Harbour Bridge during the September 2009 dust storm. 
systems. Such data highlight the complex mosaic of differing land surfaces in the Yilgarn Craton of southern Western Australia, which can be used to document landscape denudation processes (Figure 5.8b). At a more local scale, the use of very precise laser logging using light detection and ranging (LiDAR) has revolutionised the mapping of flat and apparently featureless landscapes. Standing on the banks of the Murray River and looking out over the flat floodplain, one would be forgiven for missing the minutiae of the landscape. The LiDAR images uncover an otherwise unrealised complexity, such as braided plains, scroll bars and filled billabongs, illustrating the dynamic nature and rich history of the erosion and deposition of these 'flat' landscapes (Figure 5.8c).

Why is Australia flat? As we shall see, the reasons are linked to the continent's deep and ancient geological roots, the tectonics since the breakup of Gondwana and the geomorphological processes that have operated in this framework. Let us now consider some of these controlling processes.

\section{Tectonic controls of flatness}

Australia became the island continent when it was finally released from its long connection with Antarctica. The breakup of Gondwana along the southern margin of Australia took around $100 \mathrm{Myr}$ to complete. It was not until $c a 34 \mathrm{Ma}$ that final separation had occurred. Rifting also occurred on the eastern margin when the Tasman and Coral seas opened and India and other Asian fragments broke from the western margin (Chapter 4). Since the break, Australia has drifted more than $3000 \mathrm{~km}$ to the north-northeast, at a rate of 6-7 cm per year

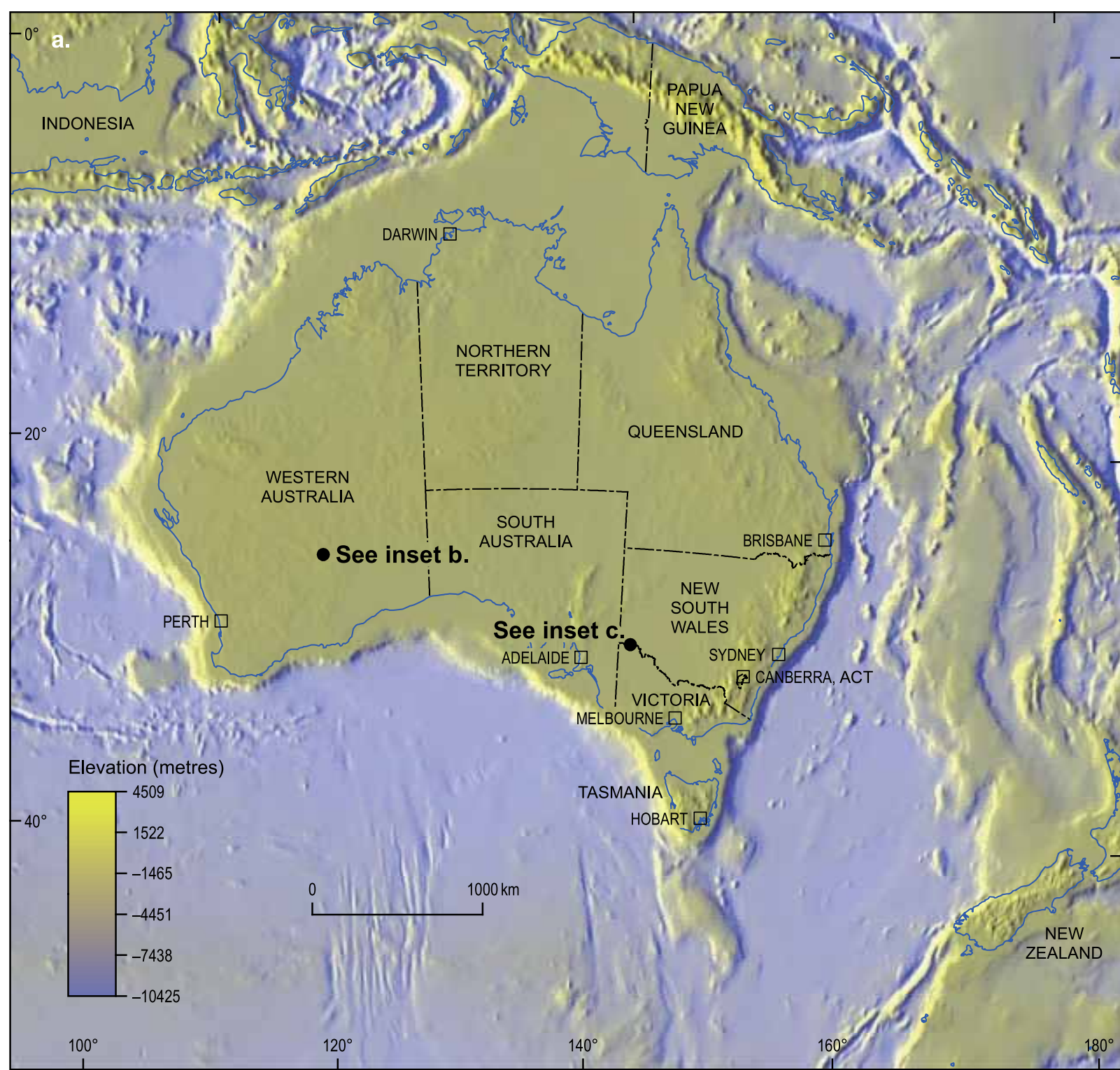

Figure 5.8: (a) Digital elevation model of Australia and its surroundings; seafloor on the west, south and east; and New Guinea to the north. The flatness of the Australian landmass stands out in contrast to the mountainous land to the north. (Source: Mike Sandiford, pers. comm.). (b) Digital elevation model from Shuttle Radar Topography Mission (SRTM) of southwest Western Australia, showing the small rises and scarps in an otherwise flat landscape. (c) Digital elevation model from LiDAR data over the Murray River corridor in South Australia, showing the subtle changes in elevation related to the evolution of the river. 

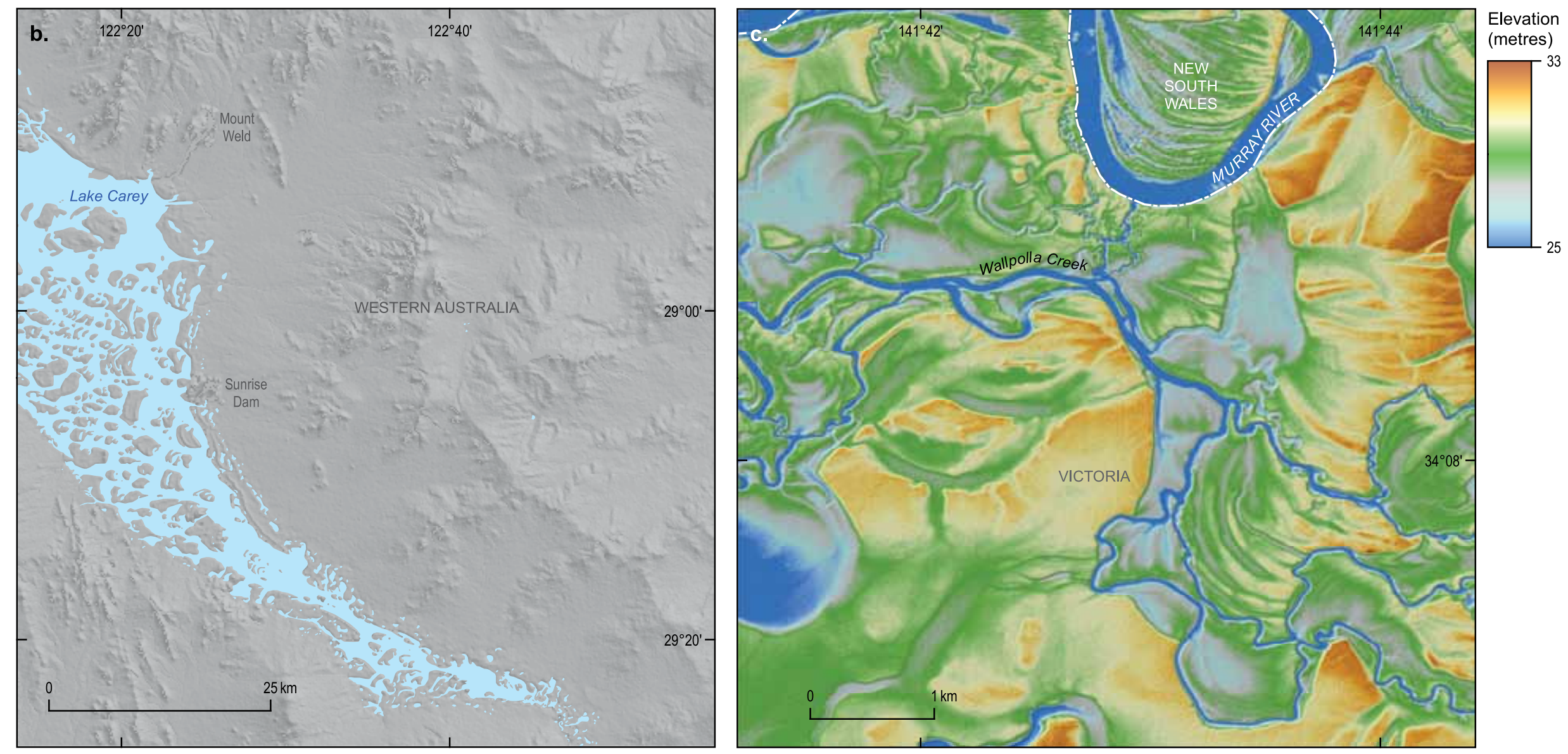

(Chapter 2). Impacts of the breakup, such as raised margins on the east and west, are still obvious in the landscape today. The drift north, in addition to moving Australia through increasingly warmer (and drier) climate belts, had the effect of tilting the continent to the north. This tilting may have been caused by movement of the Australian continent over irregularities in the geoid, rather than subduction pull of the oceanic lithosphere attached to the northern margin of the plate.

The Australian continent is located roughly in the middle of its plate and, except in the north, is far from active plate margins. Even there, the active margin is reflected in the mountains of New Guinea rather than on Australia. The distance from active margins has been an important tectonic factor in reducing the topographic consequences common in convergent margins, such as volcanoes and collisional mountain ranges associated with crustal thickening.

With regard to its flatness, Australia is different from other continents, but in degree rather than kind. Other Gondwana continents have high edges and low centres, and Africa and India are also surrounded on at least three sides by passive margins. Only South America is so different, in that, whereas it has a passive margin on the east, it has an active one on the west (Figure 5.9).

The strength of a continent is largely determined by the thickness of the lithosphere; in addition to the continent's intraplate position, Australia derives underlying strength from its very thick lithosphere. Continents with old (Archean) cratons tend to have thick lithosphere that is also cold and buoyant, making it strong and difficult to destroy (e.g. by subduction processes). A typical global continental average lithospheric thickness of around $90 \mathrm{~km}$ occurs in the younger east (Tasman Element). However, the centre and 


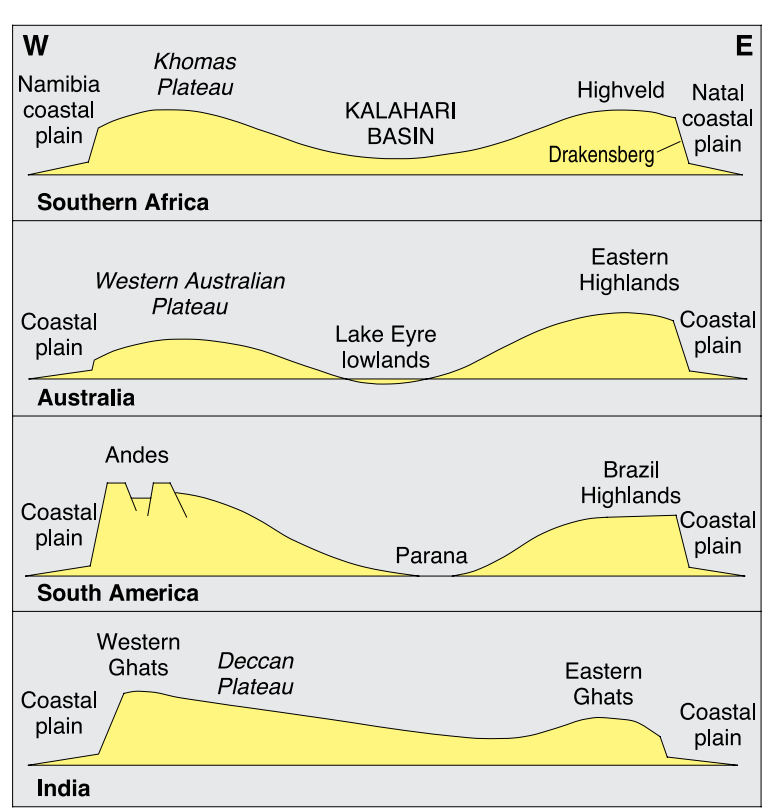

Figure 5.9: Schematic sections across four post-Gondwanan continents, showing the general saucer shape that all exhibit. (Source: Pain, 1985) most of the old western cratons are underlain by lithosphere more than double the global average at more than $200 \mathrm{~km}$ thick (Chapter 2). Apart from a region within central Australia, the heat flow across the continent is low (Chapter 10), adding to the overall strength. This strength also means that the continent is difficult to deform and create uplifted mountain areas. The combination of intraplate position and lithospheric thickness is a fundamental reason for the relative stability of the Australian continent, and is why the ancient geological record has been so well preserved.

The last major orogenic event in Australia occurred around $250 \mathrm{Ma}$, and consisted of accretionary events along the eastern part of the Tasman Element, with addition of the New England Orogen. Since then, the eastern highlands have developed as a result of opening of the Tasman Sea, which began about $95 \mathrm{Ma}$ in the south and spread north. The development of the eastern Australian passive margin led to the formation of the Great Divide along the axis of uplift, and the development, by erosion, of the Great Escarpment to the east. This escarpment in eastern Australia marks a major boundary between low rates of geomorphological processes on the inland side and much more active processes on the seaward side. Similar plateau edges, although not so dramatic, occur on other margins of Australia (Figure 5.10a).

The Pilbara, Western Australia, has been remarkably stable since the Archean. The region preserves evidence for many of Earth's early processes.

Image by Jim Masor

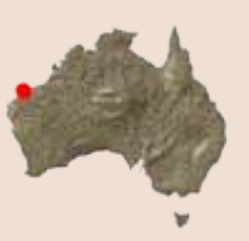

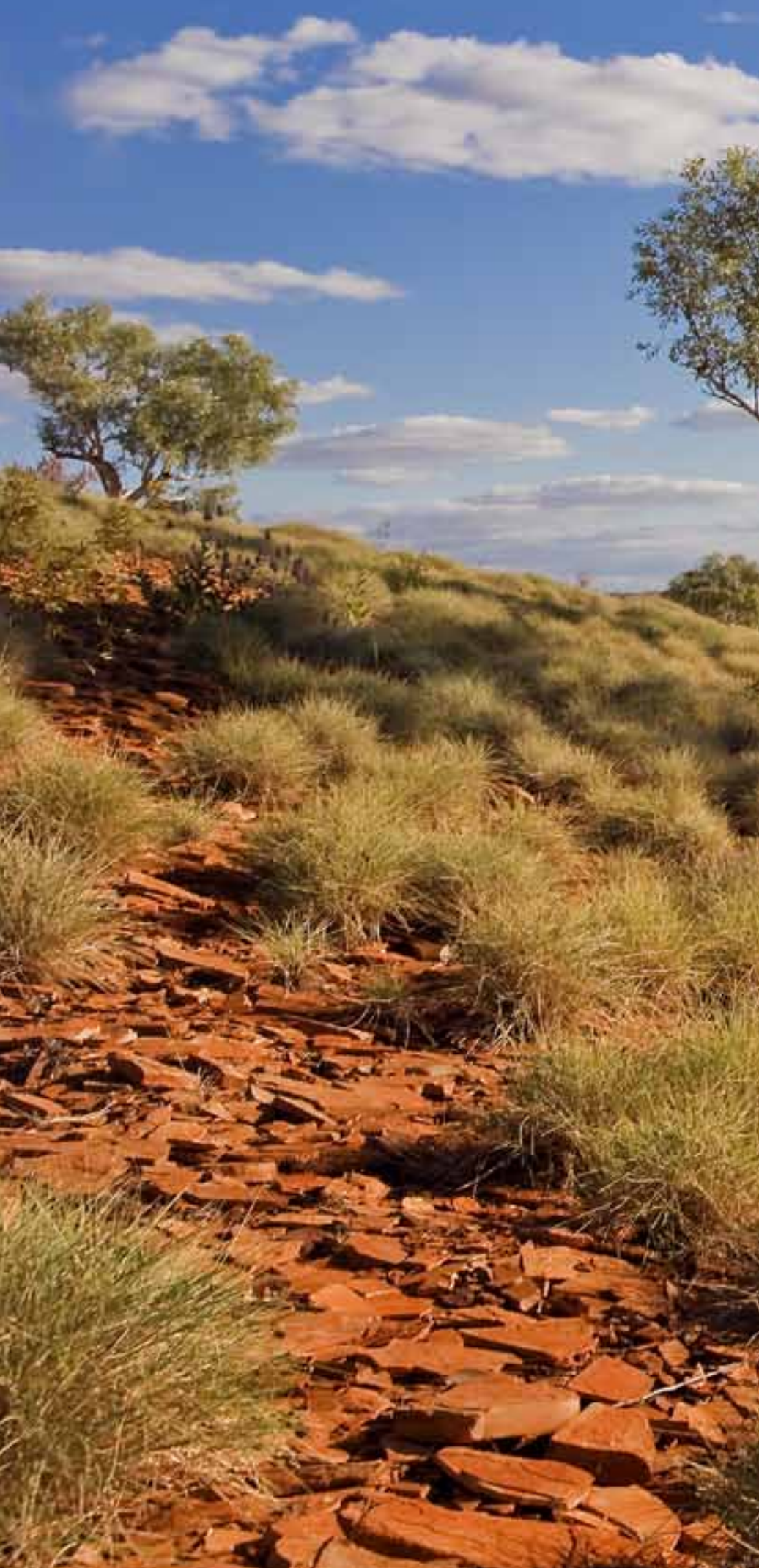


and

(3)

W. 2.

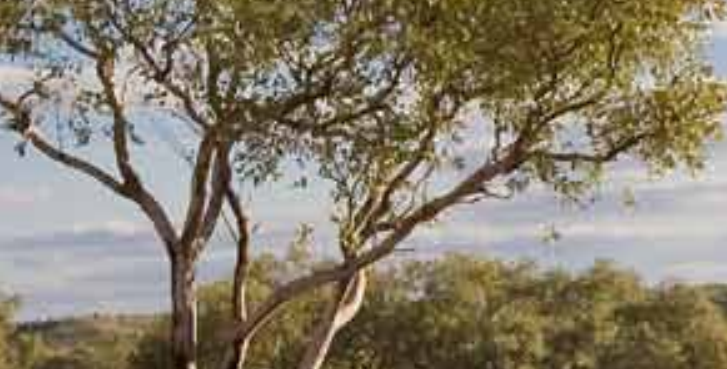

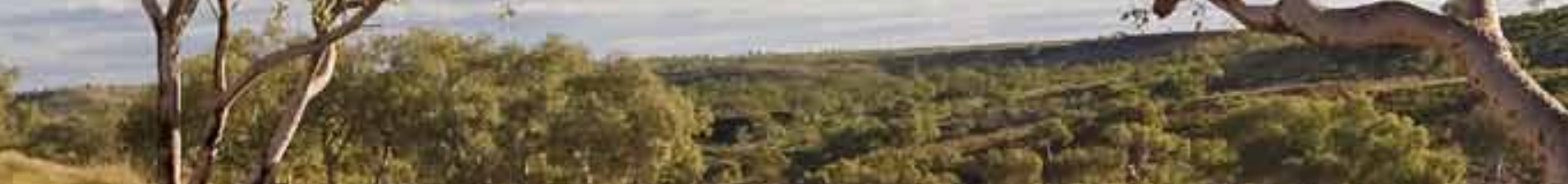

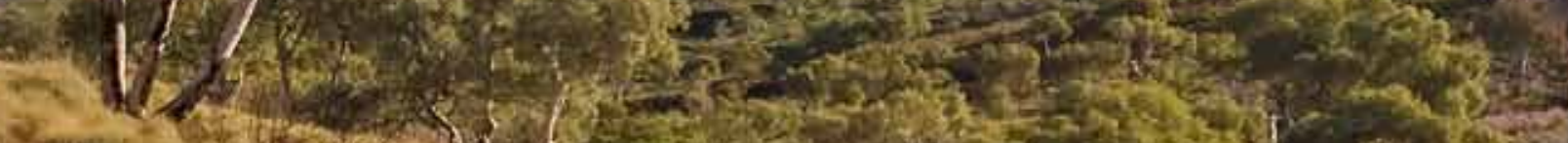
6.

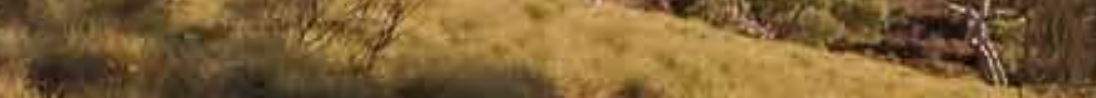

1. (x)

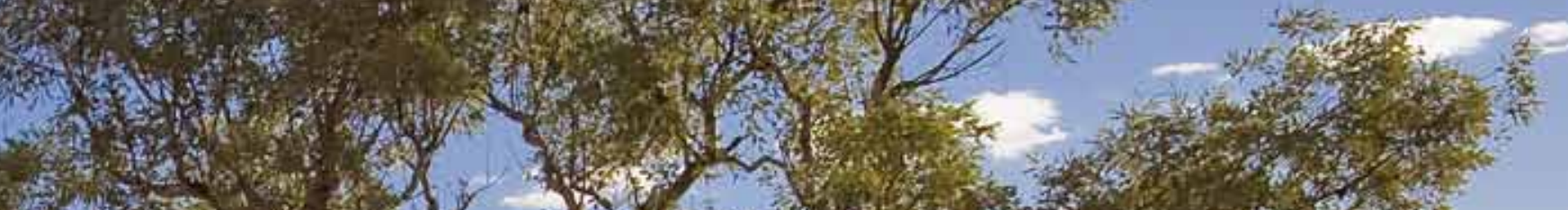
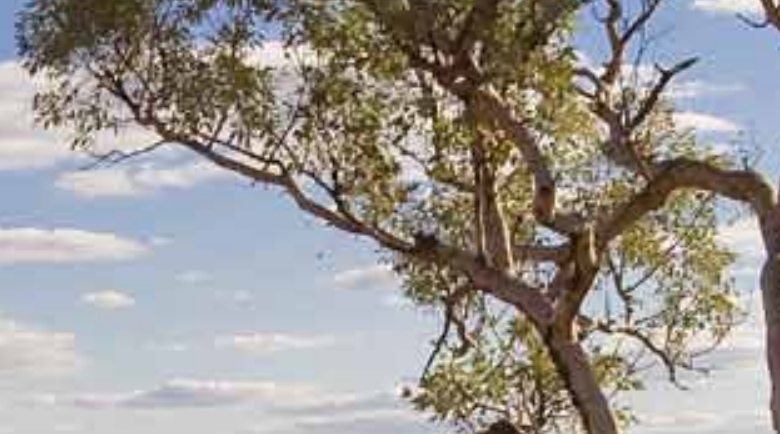

(5.2.

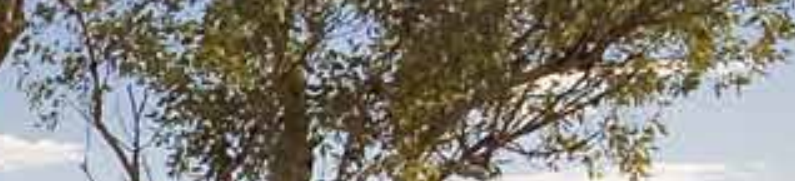

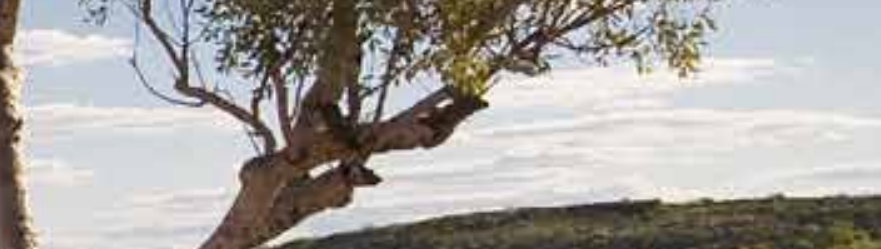

$7=$

20.

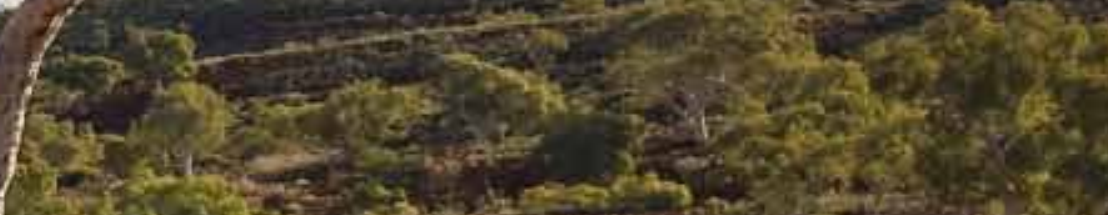

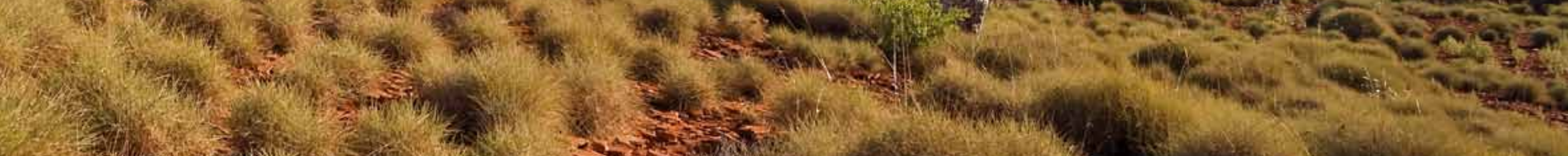

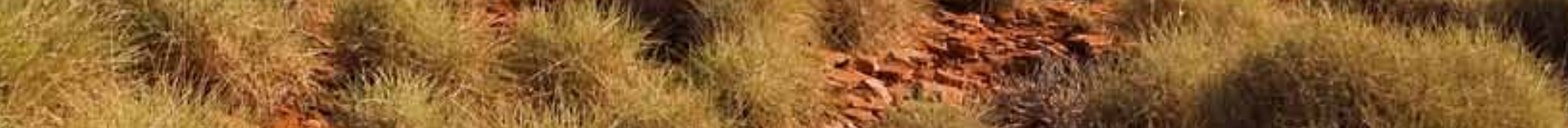

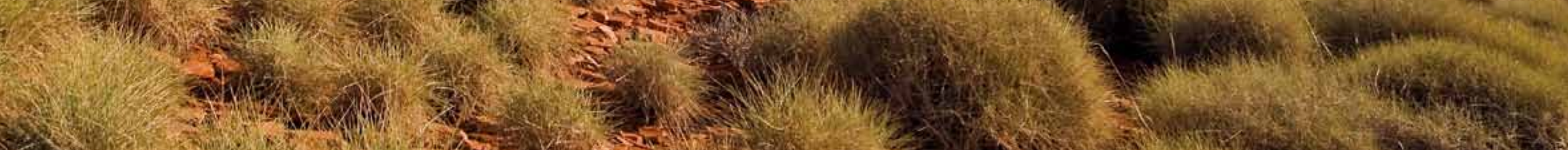

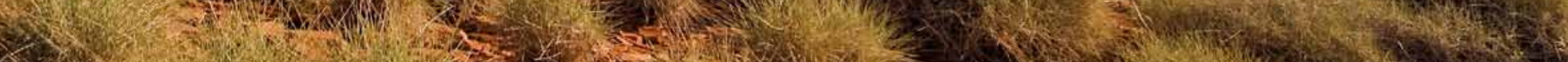

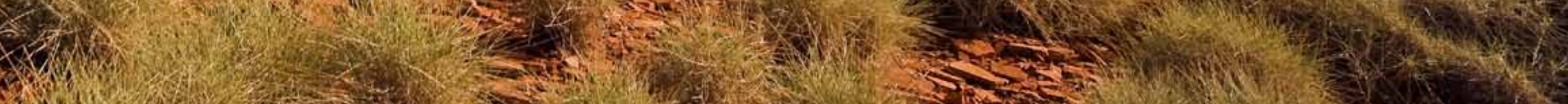

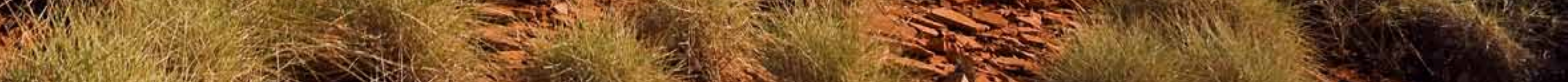

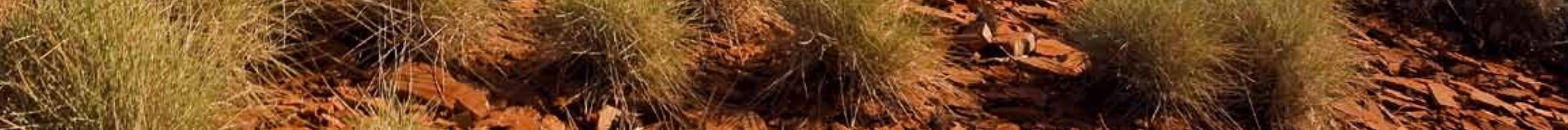




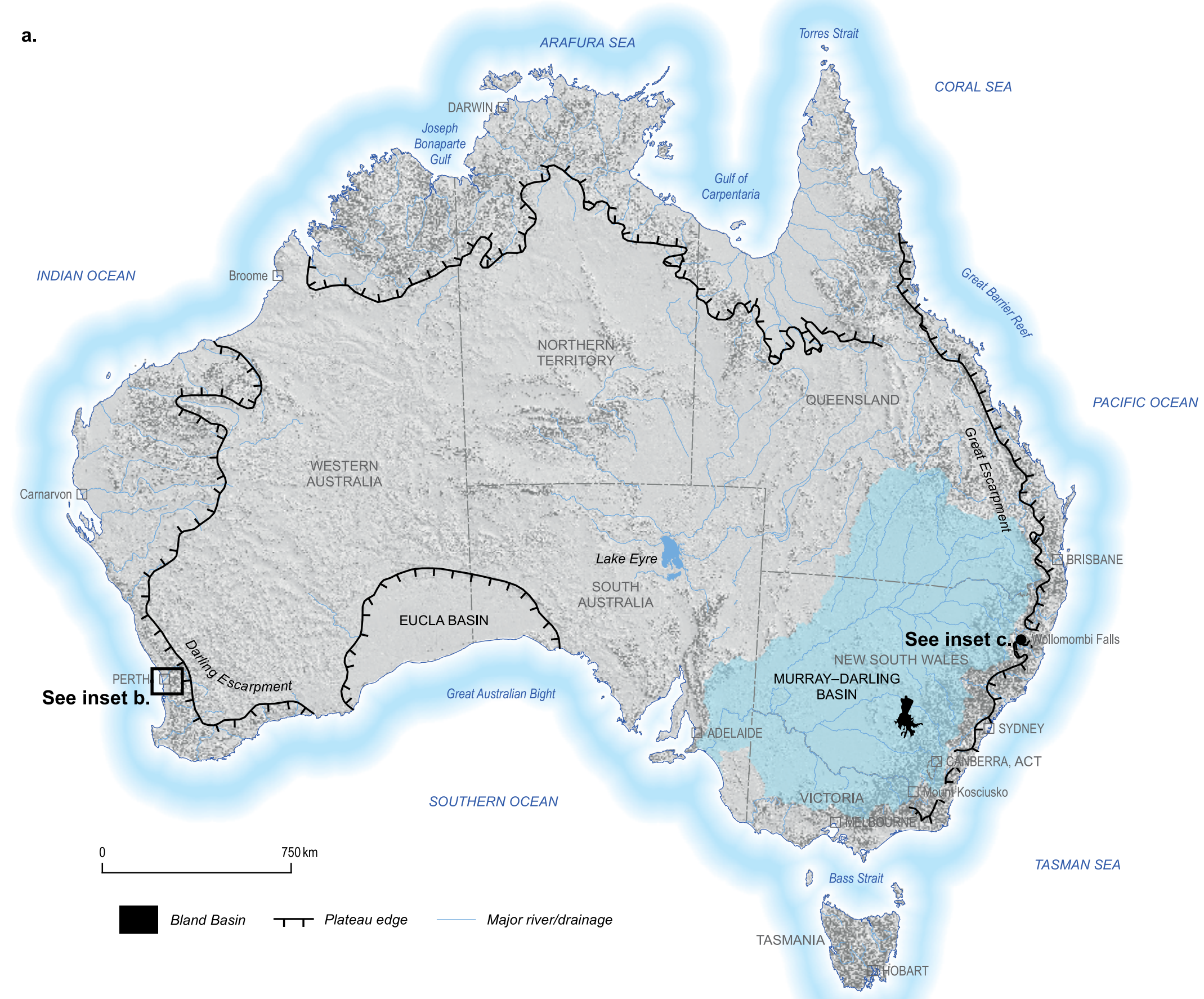

Figure 5.10: (a) Plateau edges surrounding the Australian continent, including the Great Escarpment of eastern Australia, as defined by Pain (1985), superimposed upon a digital elevation model of the continent. 


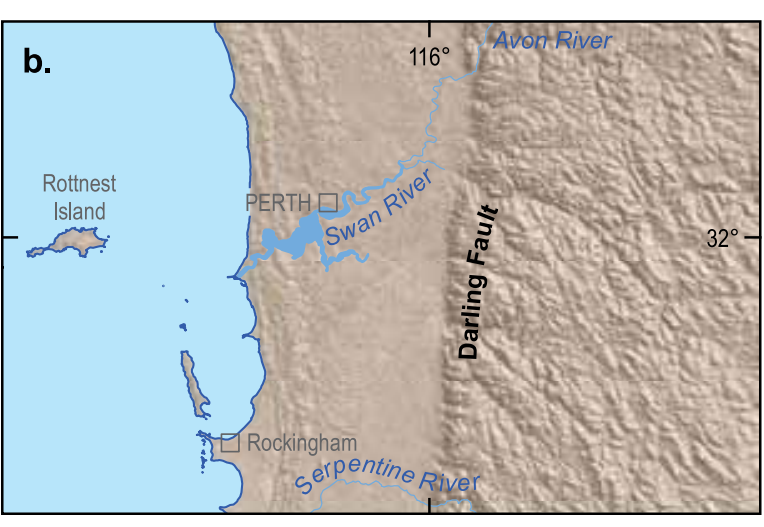

\section{Neotectonic features}

A range of geological evidence suggests that the current crustal stress regime was established during the Late Miocene (10-5 Ma), coinciding with significant changes at the Australian Plate margins, including the onset of major mountain building in New Zealand and New Guinea. At this time, intraplate uplift occurred in parts of Australia such as the Flinders Ranges (Figure 5.11).

Three distinct scales of neotectonic deformation have been described for Australia. At long wavelengths (thousands of kilometres), systematic variations in the height and inland extent of Neogene marine sediments indicate that the continent has been tilted down to the north at the same time as it moved north. This is well illustrated by the presence of Cenozoic marine sediments and shorelines along the edges of the Nullarbor Plain (including the spectacular high cliffs of the Great Australian Bight: Figure 5.12a), suggesting as much as $150 \mathrm{~m}$ uplift since the Miocene, but a distinct lack of similar sediments and shorelines in northern Australia. This tilting could also explain the difference in elevation of the Great Escarpment-up to $1500 \mathrm{~m}$ in the south but less than $50 \mathrm{~m}$ in far north Queensland.

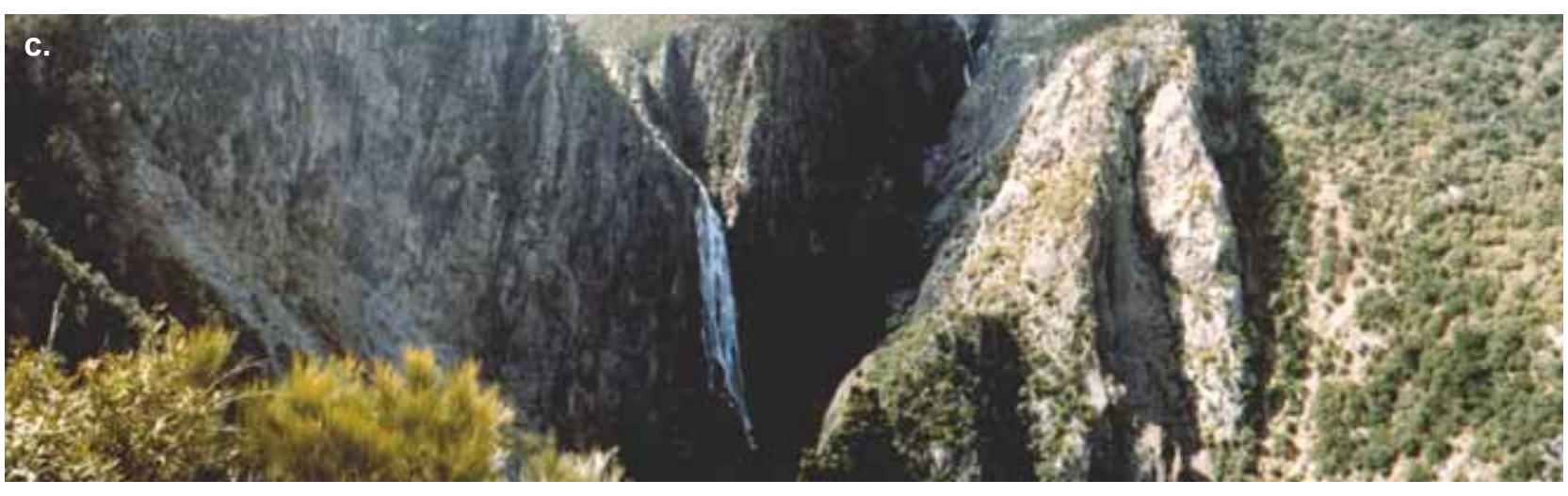

At intermediate wavelengths (hundreds of kilometres), several undulations of about 100-200 m amplitude are evident on the 1-10 Ma time-scale, including formation of the Flinders Ranges and surrounding basins such as Lake Frome and Lake Eyre. The lowest point of Lake Eyre is some $15 \mathrm{~m}$ below sea-level, which initially seems odd-how can any part of a stable continent remain below sea-level without filling up with sediment? The answer may be that Lake Eyre has only been such a low point for a few million years and that such 'dynamic topography' is in response to flow instabilities in the upper mantle. The Bungunnia palaeolake (Figure 5.13) may also have been formed in the same way. Uplift along the southern margin has also been responsible for the preservation of beach ridges millions of years old in the Murray Basin (Figure 5.13). Part of the present coast consists of a beach ridge more than $125 \mathrm{~km}$ long, behind which is the Coorong lagoon. Inland from the Coorong is another inactive beach ridge, and then others further inland of increasing age, which can be traced for hundreds of kilometres into Victoria and New South Wales (Figure 5.13). Closest to the sea, the ridges are Quaternary, whereas
Figure 5.10 continued: (b) $30 \mathrm{~m}$ pixel SRTM image of the Darling Scarp east of Perth, Western Australia. Note the dissected Archean basement of the Yilgarn Craton to the east and the down-faulted Perth Basin to the west of the scarp. Aeolianite dune systems are parallel to the coast. (c) Photograph of the Wollomombi Falls flowing over the Great Escarpment in northeast New South Wales. 


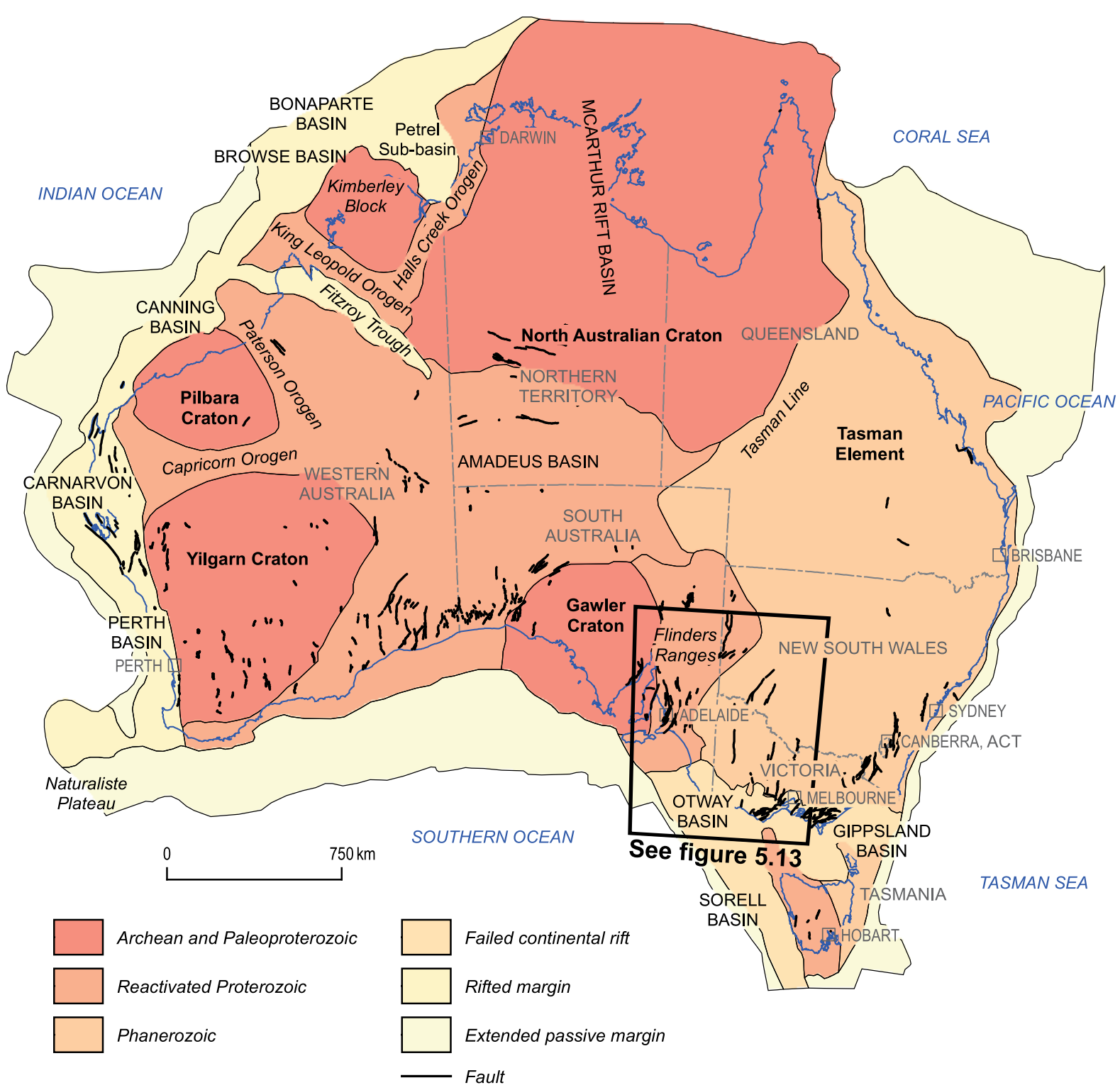

Figure 5:11: Distribution of faults in Australia that may have been active in the Late Cenozoic. (Source: Clark et al., 2011) the oldest ridges inland are Miocene in age. Further beach ridges, still undated, are preserved west of the Otway Ranges, Victoria. In the early Quaternary, coastal erosion formed the Kanawinka Escarpment, a palaeo sea-cliff and one of the most prominent and laterally extensive geomorphological features in southeastern Australia (Figure 5.13).

At low wavelengths (tens of kilometres or less) brittle deformation associated with seismicity has produced numerous fault scarps (Figures 5.11 and 5.13). Only five fault scarps are known to have been associated with historic, earthquakegenerated surface fault ruptures (Figures 5.11 and 5.13). Such faulting is typically associated with significant modifications to surface drainage, including ponding (e.g. Lake George) and diversion (e.g. of the Murray River by the Cadell Fault) On the Milendella Fault in the Mt Lofty Ranges, Proterozoic and/or Cambrian rocks have been thrust over Quaternary sediments (Figures 5.12b and 5.13).

\section{Geomorphological controls on flatness}

Australia is not only flat, but also lower in elevation than any other continent (Figure 5.8). We have seen that Australia has a deep and strong lithospheric root and is also located distant from the mountain-building effects of convergent plate margins. These tectonic controls are augmented by various geomorphological controls that helped to establish and maintain Australia’s flatness.

The Lake Eyre and Murray basins are the lowest parts of the continent. Incidentally, these basins also coincide with some of the mainland's thinnest 
crust, at around $30 \mathrm{~km}$. The highest areas are along the southern half of the eastern highlands, which also coincides with some of the thickest crust, at around $55 \mathrm{~km}$. There is, however, a poor correlation between elevation and crustal thickness, and there is far more topography on the base than on the top of the crust (Figure 2.15). The western plateau of Western Australia, extending into South Australia and the Northern Territory, also has relatively high landscapes.

Early workers JT Jutson and WG Woolnough described ancient land surfaces on the Australian continent and linked them to deep and intense weathering profiles and duricrusts. Duricrusts are regolith materials (Figure 5.14) cemented by silica (silcrete), iron oxide (ferricrete) and/or carbonate (calcrete). The geologists also assumed an overriding simplicity, invoking a single, continent-wide surface, the 'Great Australian Peneplain' (or 'Australian Pediplain'), with an extensive duricrust sheet.

The complete story is much more complex. There are old surfaces covered with silcrete and ferricrete, but they developed at different times and in restricted areas. In central and eastern Australia, the old land surfaces are characterised by mesas and plateaus. These have thick and often siliceous weathering profiles on top, which contrast with the surrounding areas where weathering profiles are much thinner (and younger). In the west, there are similar features, usually with ferruginous duricrusts, and often expressed as one-sided, sloping plateaus or 'breakaways'. These spectacular landscapes are truly photogenic, especially in soft morning or evening light that makes the regolith colours 'glow'. These surfaces, and associated weathering profiles and duricrusts, cannot be correlated over the length and breadth of Australia. They are rarely the result of a simple period of weathering followed by erosion, but rather the result of complex interactions between weathering, denudation, erosion and deposition.

\section{'Lazy' rivers}

Rivers play a major role in shaping Australia's flatness and, as they are so slow moving, they could be described as 'lazy'.

Australia's general flatness means that its river systems have a low potential head, making them for the most part slow flowing, or even ephemeral. This slow-flowing nature is amplified by the mostly arid climate. Unlike most other continents, Australia does not have a transcontinental river system fed by major highlands with permanent snow. There is the Murray-Darling river system (Figure 5.10a), fed from modest mountains with a limited seasonal snowcap, but this is nowhere equivalent to the Mississippi of the United States (Box 5.2). This lack of major transcontinental rivers, in contrast to other continents, has hindered the development of the Australian interior and is another reason why most Australians live along the coastal fringe and not inland (Chapters 1 and 6). Although Australian rivers are meagre by world standards, they are still important sources of water (Chapter 7). They feature frequently in Aboriginal Dreamtime stories and also European art-think of 'Waltzing Matilda' and the 'jolly swagman camped by a billabong' (see Did you know? 5.1).
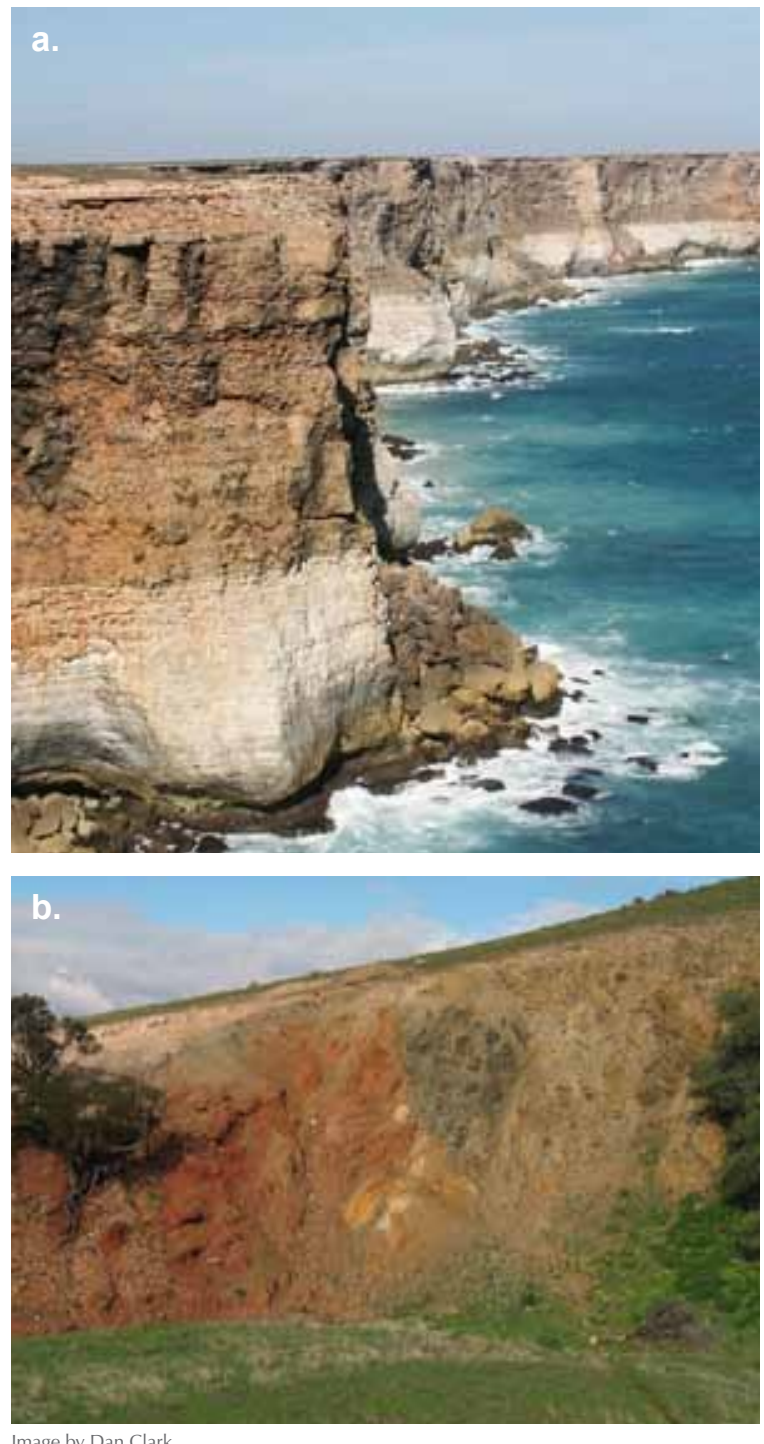

Figure 5.12: (a) High cliffs resulting from coastal erosion of uplifted Neogene marine sediments in the Great Australian Bight, South Australia. (b) The Milendella Fault thrusting Cambrian metamorphic rocks on top of Quaternary gravels in the Mt Lofty Ranges of South Australia. These gravels (in adjacent localities) record the 780 ka Matuyama-Brunhes palaeomagnetic reversal, making this a very young fault indeed. (Sources: Quigley et al., 2010; Clark et al., 2011) 


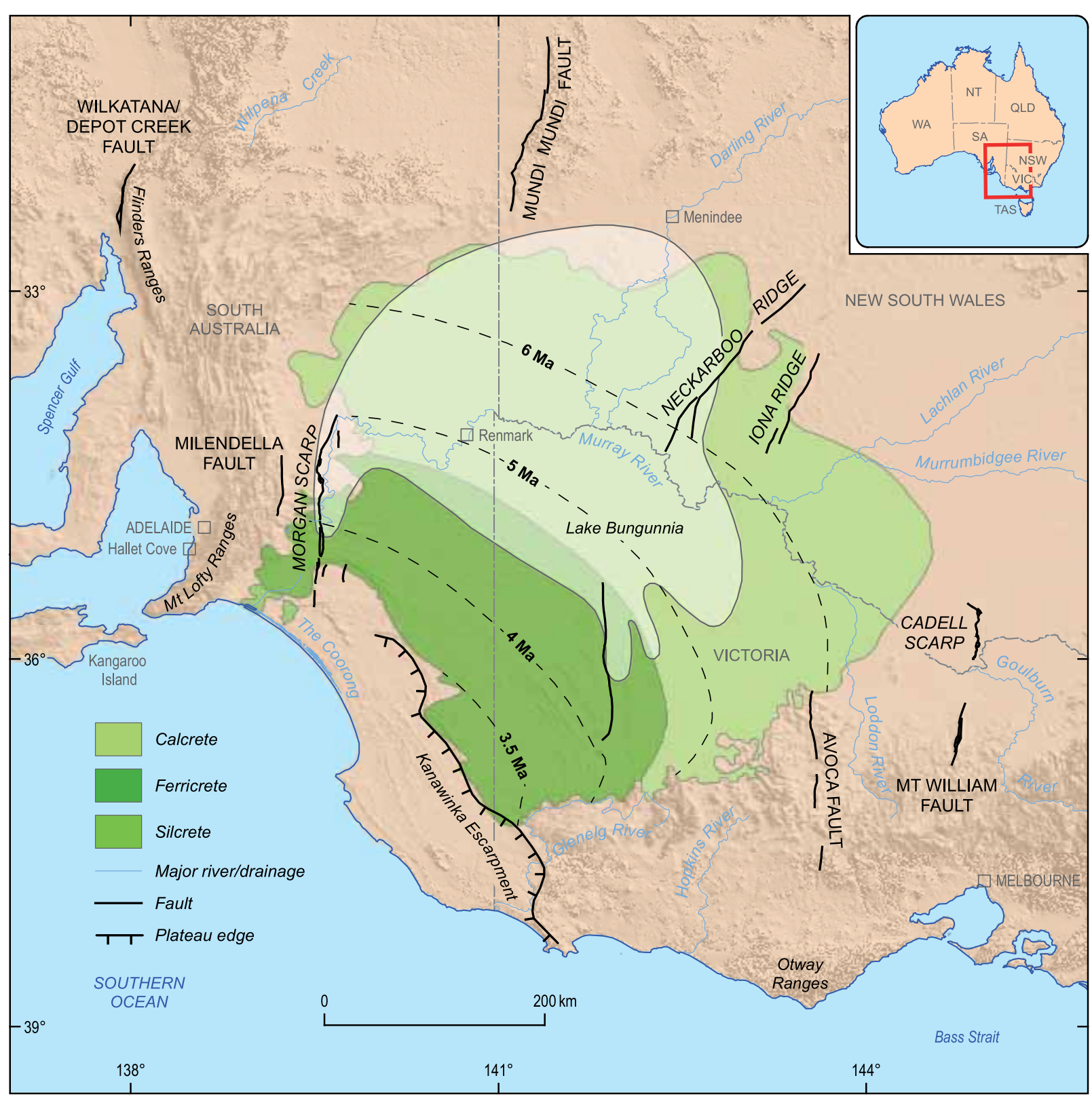

Figure 5.13: Beach ridges in the Murray Basin, southeastern Australia. Behind the modern arcuate beach ridge is a series of parallel ridges, extending back to the Miocene. It is not clear why there is a change from silcrete to ferricrete and then calcrete duricrusts dominant in the regolith as the ridges get younger, but this may be a consequence of age and weathering of beach materials.
Inland rivers in Australia have a very large flow variation, with mean annual discharges more than 1000 times more variable than those of most European and North American rivers (Table 5.1). A feature of flat landscapes, especially in arid climates, is that large areas have internal drainage. Most Australian rivers also show a consistent loss of flood discharge downstream. Some end in flood-outs, with water disappearing altogether, while others end in closed lake systems. Nearly half of Australia consists of areas that either drain internally or lack recognisable river systems (Figures 5.1 and 5.15). Thus, almost half of the Australian continent provides no runoff to surrounding oceans, in dramatic contrast to all other inhabited continents. This lack of runoff means that limited terrigenous sediment reaches the continental shelf, and carbonate sedimentation is predominant offshore (Chapter 6).

The Lake Eyre drainage basin is one of the largest internally draining areas in the world, covering about $1.2 \mathrm{M} \mathrm{km}^{2}$, or some $16 \%$ of Australia (Box 1.5; Figures 5.1 and 5.15). Lake Eyre is a large salt lake that only intermittently fills with water. However, during the last interglacial, Lake Eyre was semi-permanent, fed by increased runoff from the north, probably caused by a stronger Australian monsoon. The ancestral Lake Eyre-Lake Dieriwas also much larger, perhaps $110000 \mathrm{~km}^{2}$ in area compared with $9500 \mathrm{~km}^{2}$ today, incorporating other lakes such as Callabonna and Frome into one large lake (Figure 5.15). This mega-lake would have been filled largely by inflows from Cooper Creek and the Diamantina River, which must have been more permanent watercourses at that time. 


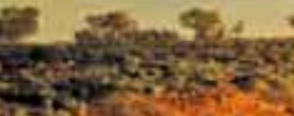
Sexis:

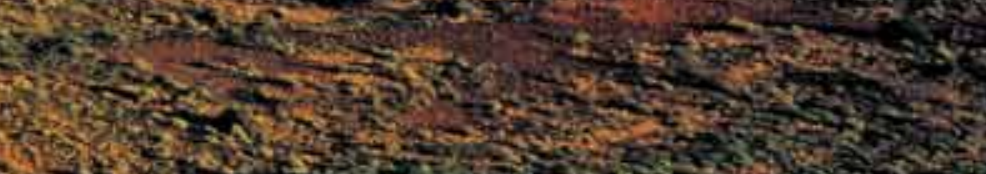

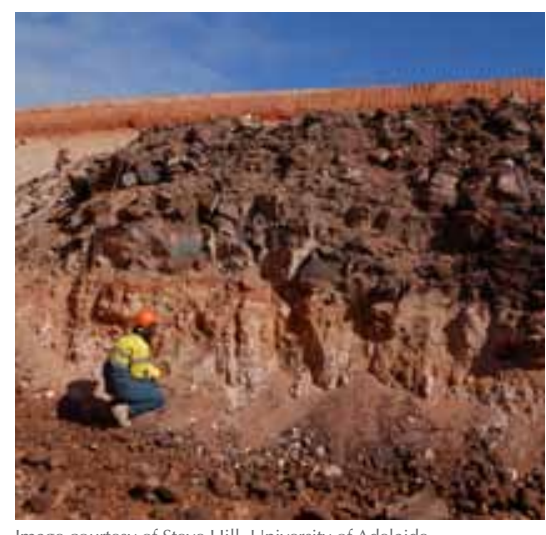

The Breakaways near Coober Pedy, South Australia; silcrete-capped mesas.

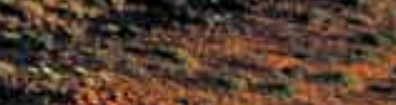

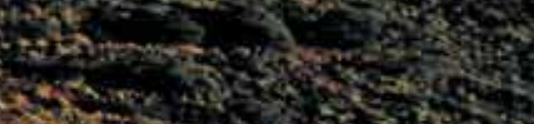
of

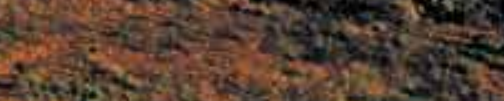
W.

rom Broken Hill, New South Wales. Massive silcrete with

rainforest leaf fossils from Fowlers Gap, New South Wales, and groundwater ferricrete from the Jacinth heavy mineral sand mine, South Australia. These resistant lithologies cap many landscape features, such as the top of breakaways. 
Not only does topography impact river morphology, so does climate (Figure 5.15). The net amount of water available for a river is dependent on the amount of rainfall and the evaporation rate. In Queensland, where rainfall is more than $10 \%$ of the total amount of evaporation, there is enough surface runoff for rivers to be integrated into well-developed channel systems. However, where rainfall falls to less than $5 \%$ of evaporation, the rivers become disconnected and intermittent. This means that sediment moving down the rivers does not always reach Lake Eyre, but is deposited along the way. An important consequence of this pattern, especially in closed basins, is that erosion and sedimentation tend, over time, to reduce the relief of these areas, thus contributing to Australia's flatness.

Along the eastern highlands, and also along parts of western and northern Australia, rivers have two distinctive parts. Above scarps or knick points, they tend to have low-angle long profiles, and flow in broad valleys. In the east, many of them cross the Great Escarpment (Figure 5.10) as waterfalls and, near the coast, they are deeply incised and tend to have steeper long profiles than inland. It is important to remember that rivers above the Great Escarpment are controlled by a local base level. They do not 'know' about their elevation, so are not influenced by uplift along the eastern highlands, until knick points work their way upstream. Thus the inland reaches behave more like rivers draining towards the interior and, because of local deposition, are also evolving towards lower relief. For example, because of local deposition, the modern Shoalhaven River above the Great Escarpment south of Sydney flows at a higher elevation than it did in the Oligocene. In this, the

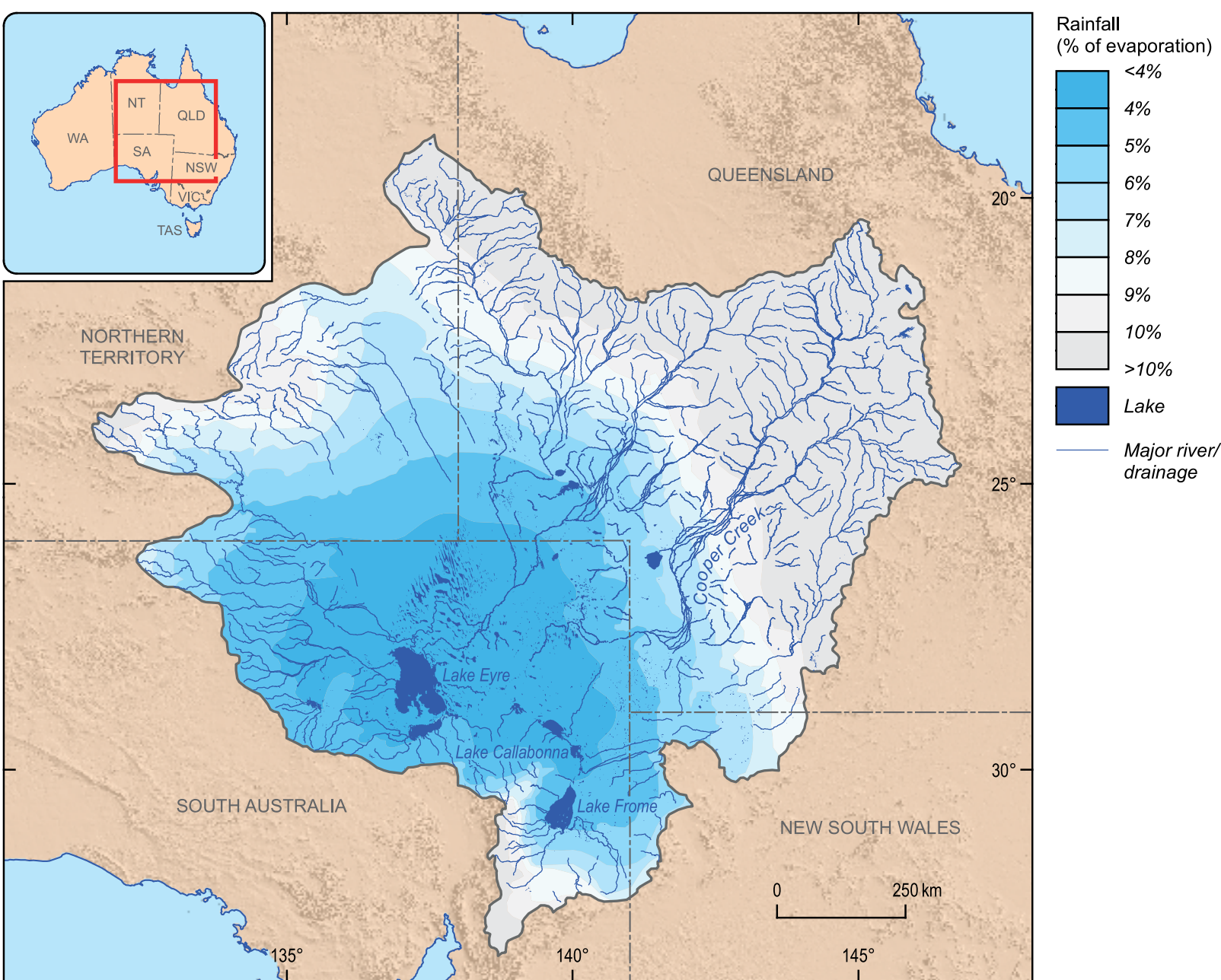

Shoalhaven is similar to those rivers on the inland side of the Great Divide; only 10\% of the Bland Basin (Figure 5.10), for instance, is erosional-the other $90 \%$ is covered in terrestrial sediments that reflect a decrease in relief.

This two-part river morphology is repeated around the edges of the Murray-Darling Basin, including the Darling River around Menindee, which has the appearance of an aeolian landscape drowning in fluvial sediments. The same pattern repeats at the Avon River in Western Australia,
Figure 5.15: Water balance for the Lake Eyre drainage basin. Note how the channels change from a dendritic drainage pattern to more disconnected drainage pattern as evaporation increases and rainfall decreases (increasing aridity) further into the centre of the basin. (Source: Bureau of Rural Sciences) 


\section{Did know?}

\section{1: Billabong—the resting place for a swagman}

The word billabong was first recorded in Australian English in reference to the Bell River of southeast New South Wales. The explorer Thomas L Mitchell recorded in 1836:

The name this stream receives from the natives here, is Billibang. It is a Wiradjuri word of southern New South Wales and northern Victoria. In the extended and current sense an arm of a river, made by water flowing from the main stream, usually only in time of flood, to form a backwater. (Frederick Ludowyk, The Australian modern Oxford dictionary)

Billabongs are important refuges for wildlife-and people-in outback Australia as they are usually the last sources of surface water in dry conditions. They feature in Australian literature, such as AB 'Banjo' Paterson's iconic 1895 poem about a swagman 'Waltzing Matilda', carrying his swag or bedroll.

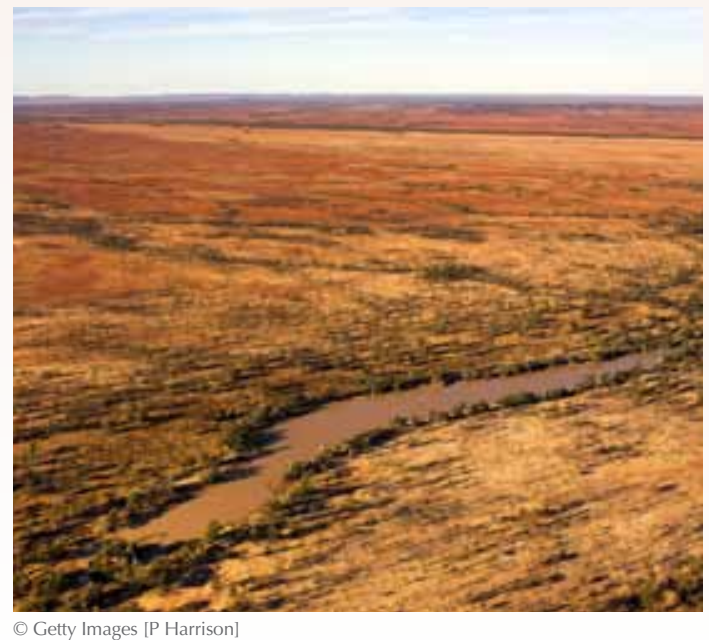

Aerial view of Outback Billabong, Queensland. where low-gradient intermittent streams flow over the Darling Escarpment (Figure 5.10b) in incised channels, and further north, at the Fortescue and Robe rivers (Figure 5.1)

The biosphere is an important factor in shaping rivers and therefore the landscape and regolith (Figure 5.2a). Plants play their part in stabilising the landscape by mediating the impact of water scarcity. In the arid zone, the patchwork distribution of plants partitions water from rainfall into overland flow zones, limiting soil erosion and creating a landscape with local runoff sources, and run-on sinks. When the surface water flow does reach ephemeral streams, the channel-associated plants modify the flow conditions and velocity.

The effects of large plants are quite obvious; for example, river red gums (Eucalyptus camaldulensis) have a stabilising effect on river architecture, which in turn influences channel flow, erosion and deposition, to the extent that sediment ridges form. With time, these ridges lengthen and coalesce into anastomosing channel forms that are characteristic of inland rivers such as Cooper Creek (Figure 5.15). Other, less immediately obvious, examples of biosphere impacts are the plant litter from species like Cassia or spinifex grasses that accumulate and alter surface water flows by creating small 'dams' in what are otherwise very low-gradient landscapes. Soil crust-forming microphytic (and ancient) organisms such as cyanobacteria, mosses and lichens, as well as fungal hyphae, also play a role in stabilising the ground surface. These fragile crust-forming ecosystems are easily damaged by vehicles and overgrazing by hard-hoofed (imported) animals. Once the crust is broken, erosion can take hold, leading to serious land degradation.

\section{Australia's palaeorivers}

Not all of Australia's rivers are obvious at the surface today. 'Palaeorivers' can be elevated in the landscape as ridge lines meandering high above the present-day plains - these are examples of inverted relief. In other cases, the palaeorivers can be concealed by younger sediments, or even volcanic flows - these are 'palaeovalleys'. We will read more about the palaeovalleys and their importance for groundwater in Chapter 7.

Inversion of relief is a common feature in Australian landscapes. Relief inversion occurs when regolith materials that initially formed in lower parts of a landscape, usually valley floors, become cemented and therefore more resistant to weathering and erosion than the surrounding material, which is higher in the landscape. Weathering and erosion of the less resistant uncemented material result in the former (cemented and resistant) valley floor being preserved high in the landscape. A good example of relief inversion is preserved as the Mirackina Conglomerate in South Australia, an alluvial silcrete that caps a series of parallel elongated mesas more than $200 \mathrm{~km}$ long, which are all that remains of a major drainage channel, complete with tributaries. Another example of inversion of relief caused by resistant ferricrete is the nodular iron ore of the Robe River deposit, Western Australia. These channel-iron deposits extend for tens of kilometres along the old valleys, and the modern valley follows this ancient path as a lateral stream (Figure 5.17). These palaeorivers are an important economic resource of iron (Chapter 9).

Palaeorivers are common on the Australian continent, and some are as old as early Neogene. Remnants of these drainage lines can be seen on 


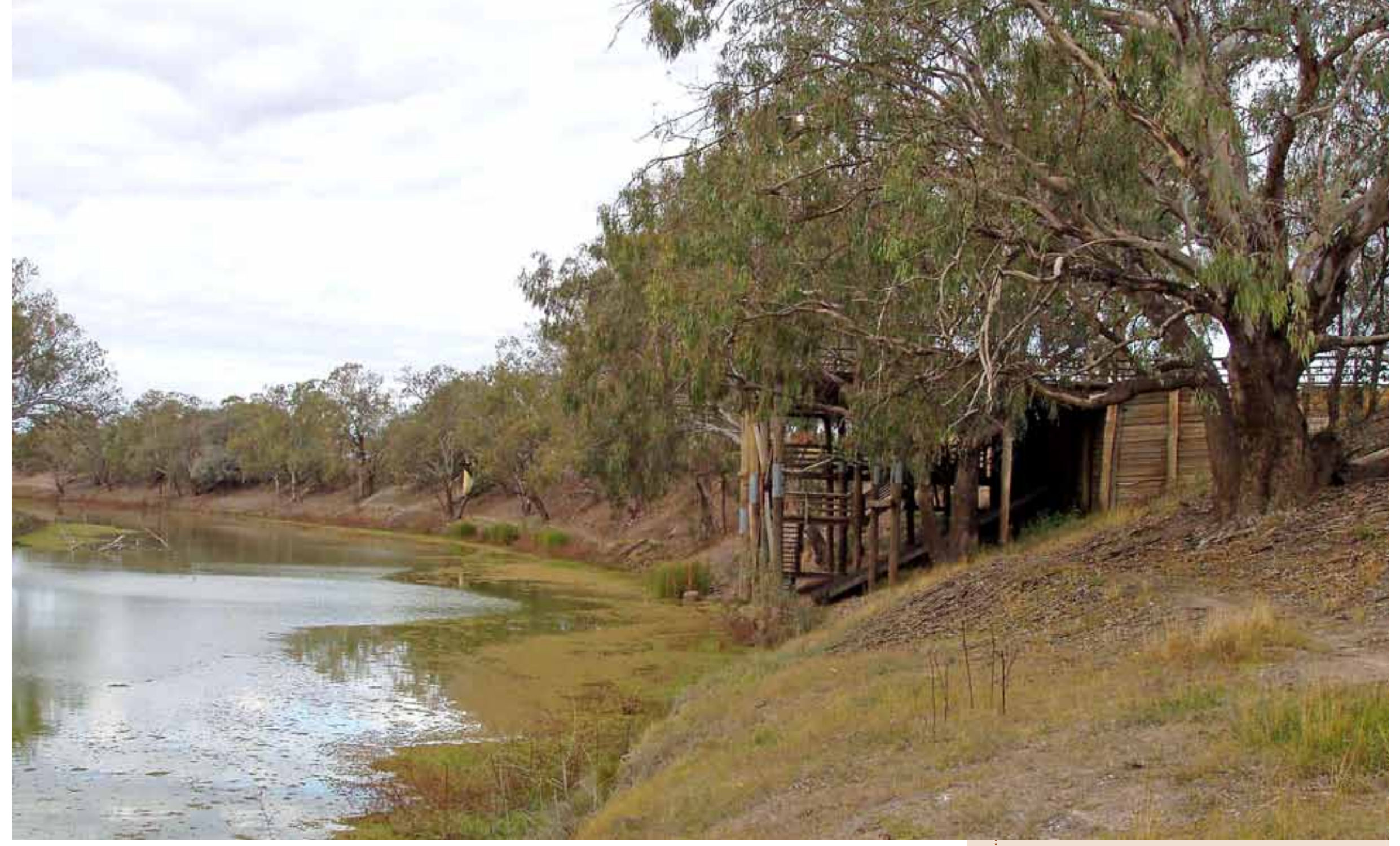

satellite imagery (Figure 2.4), and are also visible on digital elevation models (Figure 5.10a). The Eucla Basin, for example, shows many signs of palaeorivers, some of which may have reversed their direction in the Neogene because the land surface, already very flat, was uplifted and tilted. Drainage reversals may also have occurred along the eastern highlands as the continental margin underwent passive-margin uplift.

Finally, with the end of the last glacial maximum, the sea-level rose, flooding older river systems, and shifting the mouths inland by tens to hundreds of kilometres in places. The Georges River and
Sydney Harbour are rias-drowned remnants of deeper river systems. Deep submarine canyons cut the continental slope. Remnants of drainage channels can be seen on the submerged shelf inland of the Great Barrier Reef and snaking across the floor of the shallow Arafura Sea, while Pleistocene extensions of the Murray River can be traced across the southern shelf into the Murray Canyons. These changes in sea-level are just one of the impacts of long-term climate change on the Australian landscape (Chapter 6).
- The Darling River at Bourke, New South Wales. By the 1890s, around 100 paddle steamers and barges worked the river.
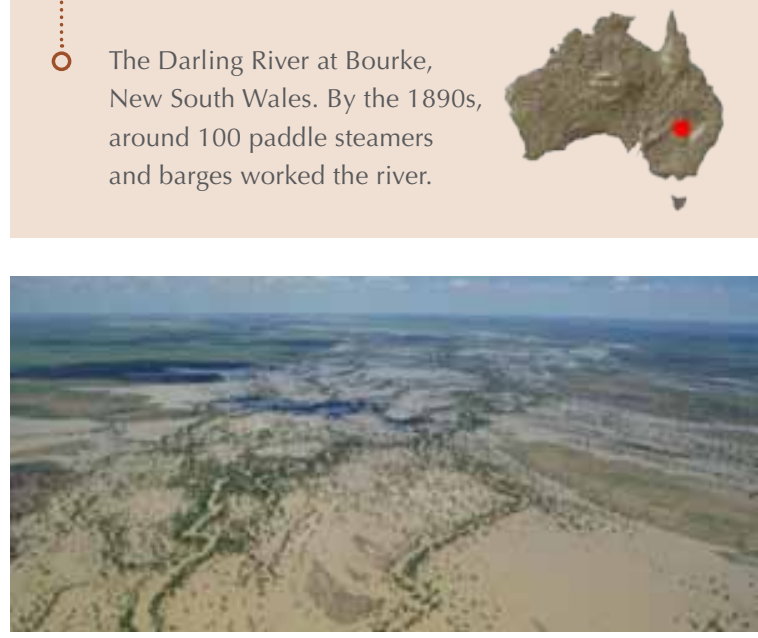

Figure 5.16: Aerial view of Cooper Creek, South Australia, in flood, January 2008. (Source: Lake Eyre Basin Intergovernmental Agreement) 


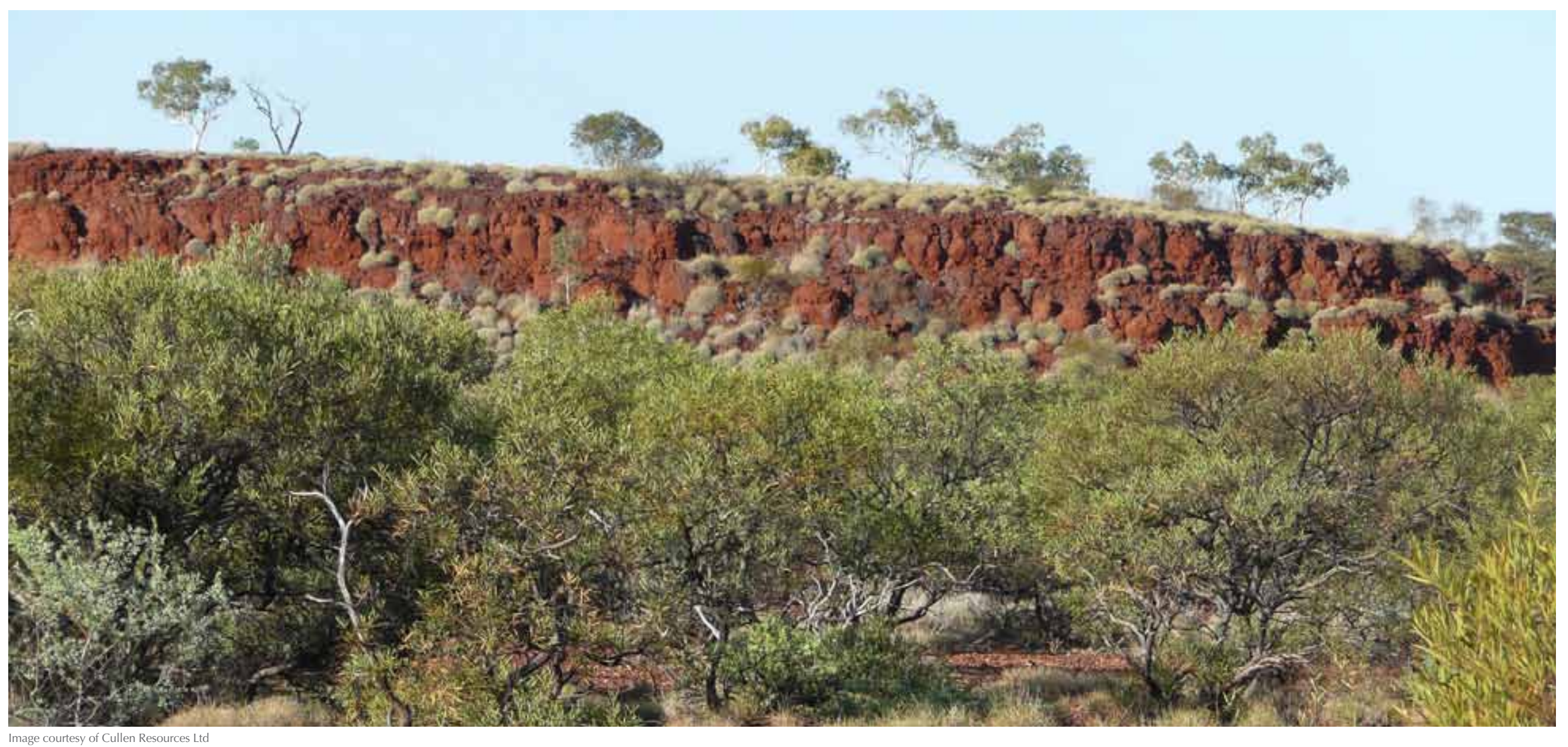

Figure 5.17: The channel-iron deposits in the Pilbara region, Western Australia, form cliffs and mesas. These cliffs and mesas were once a valley floor that became cemented (with iron oxyhydroides) and thus more resistant to weathering. Subsequent erosion has lowered the surrounding material, leaving the former valley floor high in the landscape. These deposits are highly prized for the quality of the iron ore resource (Chapter 9).

\section{Regolith-everything between fresh rock and fresh air}

Regolith can be broadly subdivided into in-situ and transported materials. In-situ regolith is weathered rock that has not undergone physical transport, although it may have undergone processes that have destroyed the primary fabric. In field descriptions, it may be characterised based on weathering intensity (slightly to highly weathered rock), or referred to in very broad terms as saprolith, which may then be subdivided into saprock $(<20 \%$ of weatherable minerals altered), saprolite ( $>20 \%$ of weatherable minerals altered), or pedolith, where the primary rock fabric is totally destroyed (Figure 5.18). Transported regolith is material that has been eroded, transported and redeposited in the landscape, and includes alluvial, colluvial and aeolian sediments.

The distinction between in-situ and transported regolith is of critical importance to mineral explorers, since it allows more confident identification of possible sources of regolith materials, either from underlying or from distant source rocks. This is particularly the case when trying to explain the origin of surface geochemical anomalies, which might be linked to buried mineralisation (Chapter 11). 


\section{Weathering}

Weathering involves chemical and mechanical processes associated with the breakdown or alteration of rocks and minerals in response to environmental conditions at or near Earth's surface. The weathered zone may grade imperceptibly into unweathered rock, especially on porous rocks, but sometimes there is a knife-sharp contact called the 'weathering front' between unweathered and deeply weathered rock (Figure 5.18). As rocks are subjected to chemical weathering, and their mineral constituents change to new, more stable, mineral assemblages, their elements are preserved in resistate minerals (e.g. zircon, monazite, rutile), are partly redistributed into new minerals, or are taken into solution. The materials lost in solution may be washed away entirely by rain and/or groundwater, or may be reprecipitated either lower in the weathering profile or downslope elsewhere in the landscape; this is the case with silcrete, ferricrete and calcrete duricrusts. Such elemental changes within the weathering profile may be large and, in some cases, result in economic mineral deposits (e.g. aluminium in bauxite, iron in iron ore). Weathering and regolith formation can dramatically alter the near-surface rock properties, especially density, porosity and permeability. These properties, along with their distribution, must be understood when applying geophysical techniques to probe beneath the regolith.

Evidence for very deep weathering comes from mining throughout Australia (Table 5.2) and logs of deep drillholes. Since groundwater has been found at depths greater than $2 \mathrm{~km}$ in places like the Great Artesian Basin, and is presumably interacting with enclosing rocks, weathering may extend to several kilometres. To accumulate such thicknesses of saprolite, weathering must have occurred at a faster rate than the weathering products were removed, which is usually associated with low relief in the landscape. The depth of weathering is not necessarily indicative of climatic conditions, because at depths of tens of metres the temperature is controlled as much by geothermal heat as by surface temperature, and the water necessary for chemical weathering can be present at shallow depths even in arid regions, as in the Great Artesian Basin (Chapter 7).

The degree or intensity of weathering can be estimated for the continent by combined analysis of gamma-ray spectrometric data and detailed elevation and slope information (Box 5.3). The map derived from this analysis depicts vast areas of intensely weathered material across the Australian landscape. The development of these large areas of intense weathering is due to the longevity of weathering and landscape preservation. Weathering intensity largely controls the degree to which primary minerals are altered to secondary components including clay minerals and oxides. As weathering intensity increases, there are changes in the hydrological, geochemical and geophysical characteristics of the regolith. Intense weathering is one of the factors in the low fertility of Australian soils (Box 5.3).

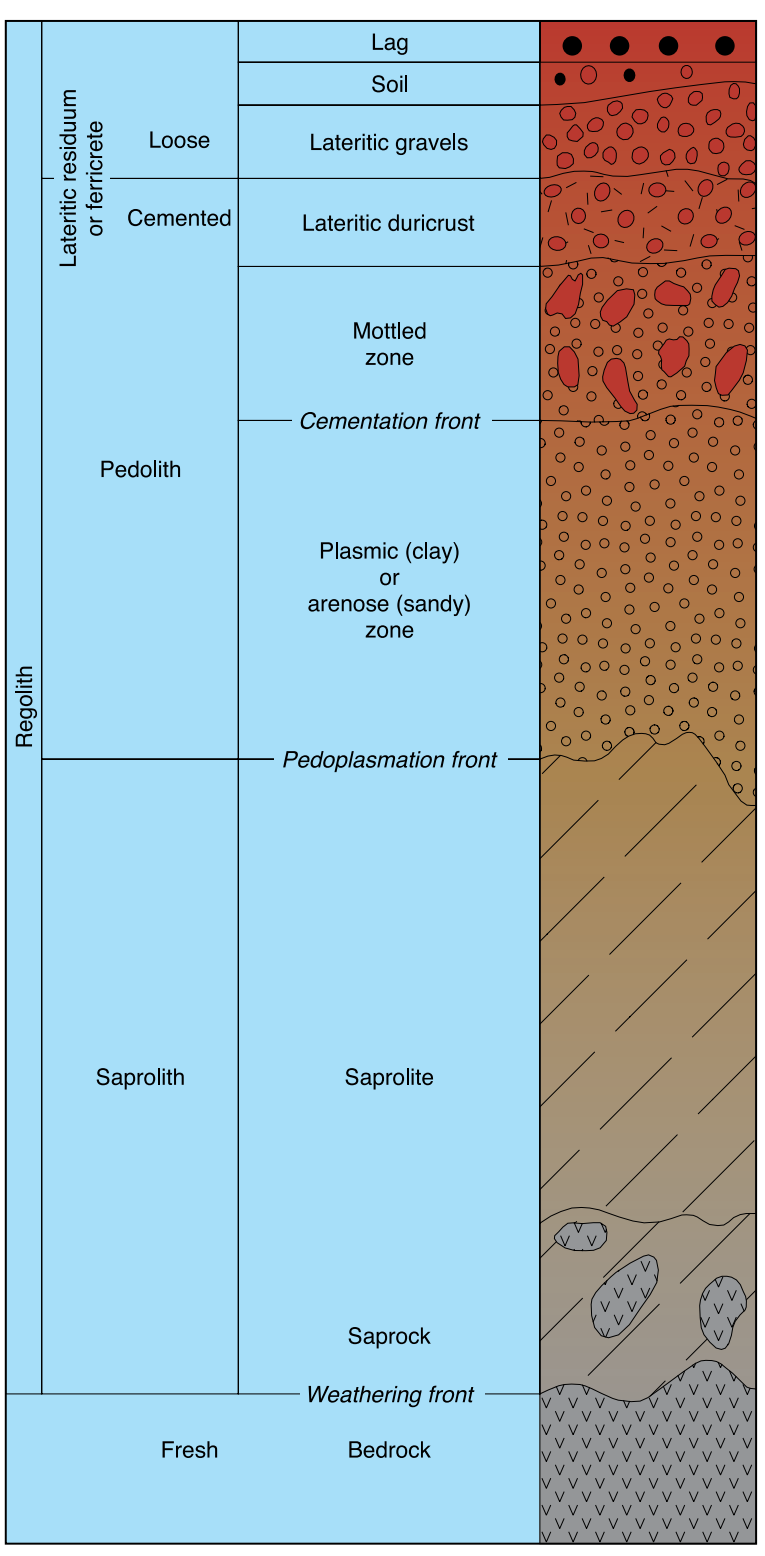

Figure 5.18: Regolith profile. (Source: modified from Eggleton, 2001) 

(BOX 5.3)

In Australia, the regolith profile can be up to several hundred metres thick. These deep profiles are partly a function of prolonged and deep weathering of the underlying bedrock and their preservation. Weathering involves chemical and mechanical processes that break down or alter rocks and minerals at or near Earth's surface, and is a prerequisite for material to be eroded. The interplay between weathering and erosional processes across different temporal and spatial scales is fundamental to understanding the nature and evolution of the landscape.

In Australia, it is possible to make a continent-wide map that estimates the intensity of weathering by using a combination of gamma-ray spectrometric, digital elevation and geological data. The weathering intensity map can be used to assess chemical and physical denudation processes, and the relative rates of regolith formation and removal over regional areas. Weathering has a major influence on the permeability and porosity characteristics of the soil and underlying saprolite, which in turn influence groundwater pathways and soil fertility. Deeply weathered landscapes often contain significant salt stores that can lead to soil salinity and saline discharge (Chapter 7 ). In terms of mineral exploration in regolith-dominated terrains, weathering can dilute or enrich pathfinder elements at the surface. So surface geochemical surveys can be interpreted in the context of variably weathered and leached landscapes. The weathering intensity map also has the potential to provide information on secondary enrichment processes within the regolith (e.g. palaeochannel uranium-bearing calcrete deposits).

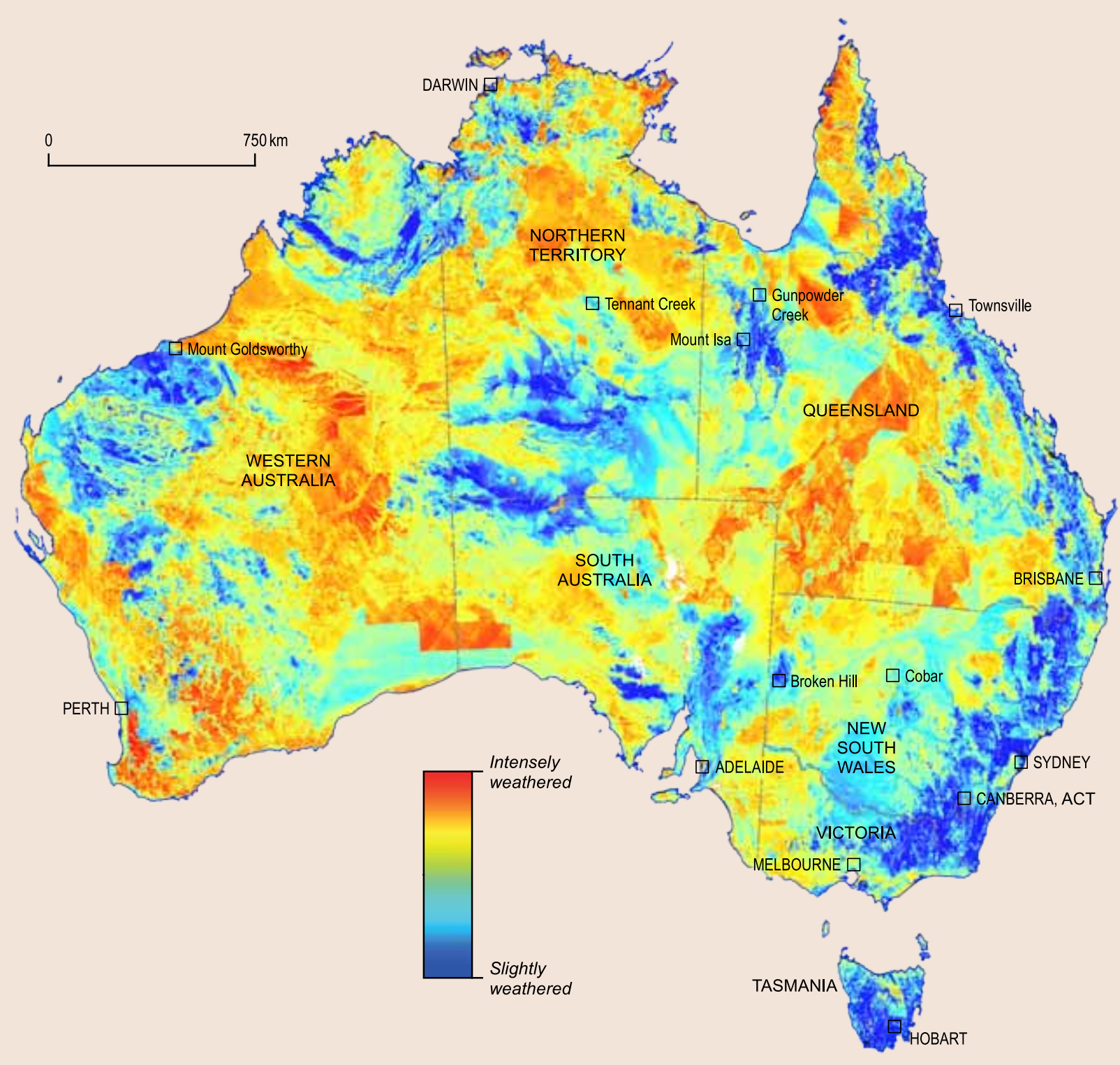

Figure B5.3: Weathering intensity map for Australia. The large areas of warm colours indicate the extent of intense weathering across the continent. Blocky parts of the image occur over gaps in the gamma-ray spectrometric data. (Source: Wilford, 2011) 
Table 5.2: Examples of deep weathering in Australia

\begin{tabular}{ll|l|l} 
Weathering & Thickness & Location & Notes \\
$\begin{array}{l}\text { Oxidation, leaching and secondary } \\
\text { enrichment in sulfide ores }\end{array}$ & $150-200 \mathrm{~m}$ & $\begin{array}{l}\text { Cobar and Broken Hill (NSW), Gunpowder } \\
\text { (Qld) and Tennant Creek (NT) }\end{array}$ & \\
\hline Oxidation & $350 \mathrm{~m}$ & Wingellina (SA) & $250 \mathrm{~m}$ bsl \\
\hline $\begin{array}{l}\text { Oxidation and leaching of } \\
\text { Cu-bearing carbonates }\end{array}$ & $800 \mathrm{~m}$ & Mt Isa (Qld) & $170 \mathrm{~m}$ bsl \\
\hline Leaching and enrichment & $250 \mathrm{~m}$ & Mt Goldsworthy (WA) & \\
\hline
\end{tabular}

Note: Localities are in Figure B5.3.

Erosion eventually starts to remove in-situ regolith materials, including the saprolite. Large blocks of unweathered rock (corestones) tend to be left behind, and make distinctive landscapes, such as granite tors (Figure 5.19a). At a larger scale, erosional remnants can be as big as the Uluru monolith (Figure 5.19b), which rises $348 \mathrm{~m}$ above the surrounding plain. In this dramatic landscape, it is interesting to wonder where the huge volume of eroded material was transported and redeposited.

Modern alluvium in southeast Australia is of mixed composition, and contains pebbles of basalt, shale, granite or whatever occurs in the catchment. Older alluvium is less diverse, and the oldest gravels, of Cretaceous to Eocene age, consist almost entirely of quartz. This is because of continent-wide deep weathering in the Mesozoic and early Cenozoic. At that time, there was no fresh rock exposed, and the only hard, unweatherable material available for bedload in rivers was quartz. Later saprolite was completely or partially stripped, exposing more and fresher rock. Over much of Australia where thick saprolite is still preserved, it may not be related to younger or present-day weathering. Some weathering profiles are related to palaeo-weathering, and may be preserved under younger sediments or basalt flows. In the case of old alluvium, some is buried under Cenozoic basalt as 'deep leads', including deposits of gold, diamonds, sapphires and other resistate minerals.

\section{Soils and salt}

The age and style of evolution of the Australian continent has meant that Australian soils are generally poor by world standards. They also formed very slowly and in most areas are very thin (Box 5.4). Even if there were enough water, most are not naturally fertile because plant nutrients have long since been removed by weathering. Australian agricultural soils, generally speaking, are deficient in a number of trace elements including copper $(\mathrm{Cu})$, cobalt, manganese $(\mathrm{Mn})$, zinc $(\mathrm{Zn})$ selenium, iodine, molybdenum (Mo), boron, iron (Fe) and sulfur.

Australia's nutritionally poor soils mean that the Western Australian wheat belt, for example, has low average wheat yields ( $2 \mathrm{t} / \mathrm{ha})$ compared with other wheat-producing areas of the world (e.g. United Kingdom at 7.78 t/ha, or China at
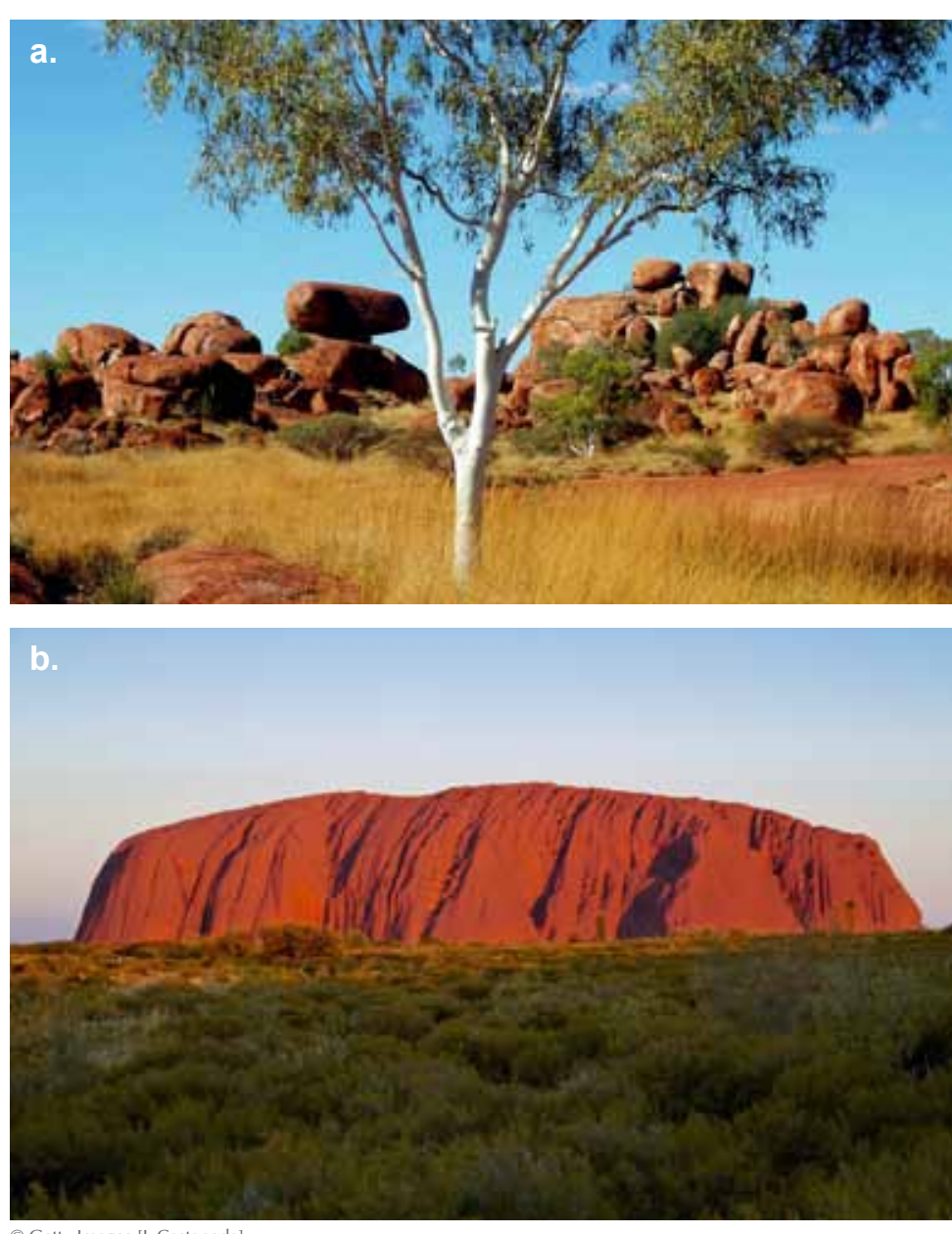

Figure 5.19: (a) Granite tors—-the Devils Marbles of the Northern Territory. (b) Uluru (Ayers Rock), Northern Territory. Australia's iconic landscape feature near the centre of the continent. 


\section{O HOW FAST DO SOILS FORM?}

Soil formation is broadly controlled by five factors: climate, organisms, parent material, topography and time. By studying soils on similar parent materials of different ages within a restricted geographical area, the first four factors can be held approximately constant and rates of soil formation can be calculated.

This has been done in north Queensland in the semi-arid region west of Townsville (ca 500 mm/ year rainfall), where soil depths were measured on basalt lava flows ranging in age from 13 ka (essentially zero soil depth) to several million years, showing that net soil formation rates were ca $0.3 \mathrm{~m} / \mathrm{Ma}$. In comparison, soil formation rates on basalt lava flows in the humid region inland of Cairns (Figure 5.20) (4000 mm/year rainfall) are an order of magnitude higher.

Ultimately, soil formation represents the balance between the processes of soil creation (e.g. weathering, biological activity and aeolian additions) and erosion (e.g. surface erosion and leaching). In the case of soil formation on basalt lava flows, weathering of the fresh rock is a limiting factor. Soil formation is significantly faster on transported, pre-weathered parent materials such as alluvium, where soil depth is controlled much more by biological activity. Biological mixing (bioturbation) rates in soils in northern Australia, where termite activity predominates, have been measured in the range $0.02 \mathrm{~mm} /$ year to $0.4 \mathrm{~mm} /$ year, which is equivalent to the upper $1 \mathrm{~m}$ of soil being completely mixed in 50 kyr to 2500 years respectively.
Australia tends to have relatively thin and agriculturally poor soils. They are also fragile, making them prone to erosion and loss to fluvial and aeolian processes (as dust storms).

Other soils are old, leached and tired. A common phenomenon in Australia's wheat belt is that of sodic soils. These are old, clay-rich, often alluvial soils that have an excess of sodium $(\mathrm{Na})$ bound to clay particles. These soils are known to be dispersive and hard setting, meaning that they slake (disperse) under rainfall or irrigation and are easily eroded, and set almost as hard as concrete when dry. They are also poorly wetting, meaning that they form a surface barrier to water penetration. These soils can also form a hard-setting barrier at the base of tillage, meaning that they can also become water saturated-the poor old farmers can't win. This means that sodic soils are difficult to maintain, are hard to till and are hard to crop. The most effective treatment for these soils is the addition of large amounts of gypsum to displace the $\mathrm{Na}$ ions with calcium ions, causing the soils to flocculate, forming flocs, or sand-sized clay aggregates, which better allow water penetration and improve soil structure.

Another problem with old, tired, clay-rich soils is that of excess tilling causing soil erosion, much like that which occurred in the dust bowl of the American central west in the early 20th century. Australia is a world leader in sustainable agricultural practices involving tracked vehicles (rather than wheels, to reduce soil compaction), minimum tillage (directly seeding using minimum till and seed-drill technologies, rather than turning over the entire topsoil), zero tillage (using seed-spreading technology) and stubble retention (not burning or ploughing-in stubble from previous crops). New technologies also allow the direct application of seed, fertilisers and pesticides by using satellite guidance to avoid over- or under-distribution and all help to retain soil structure and soil fertility as well as inhibit soil erosion by wind and water.

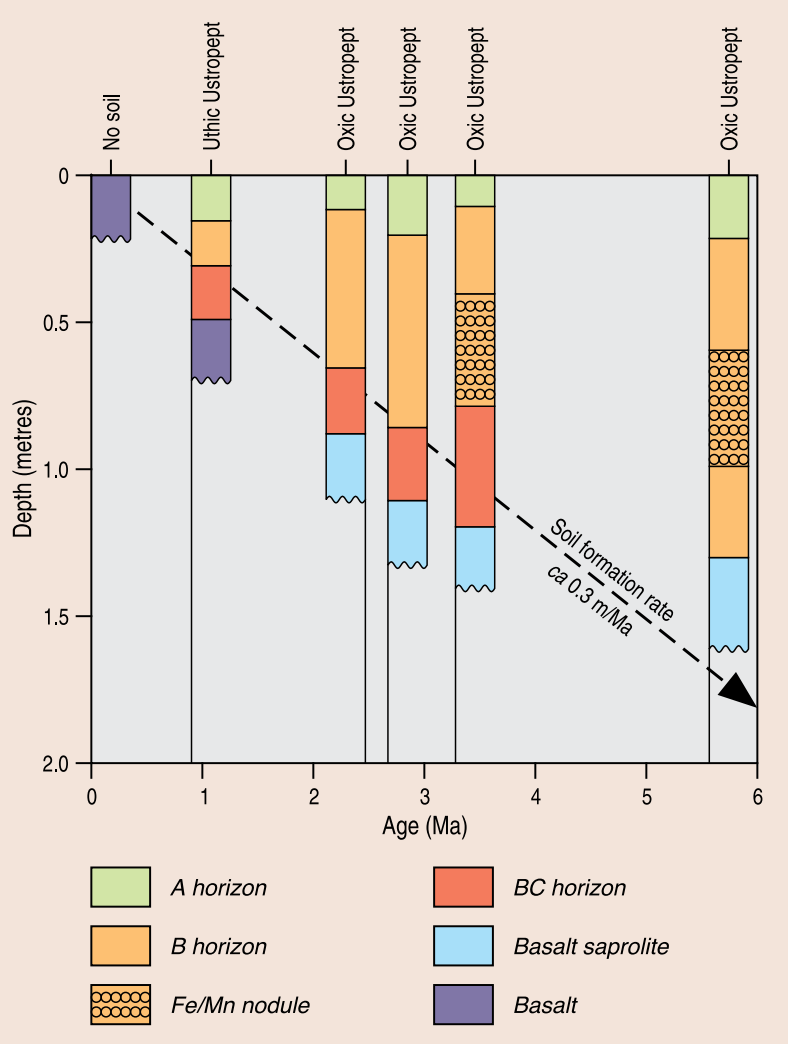

Figure B5.4: In the semi-arid region west of Townsville, Queensland, soil forms at an average rate of $0.3 \mathrm{~m} / \mathrm{Ma}$. Calculations based on soil depths developed on basalts of varying age. (Source: Pillans, 1997) 
3.93 t/ha: 2003-04 figures). Even floodplains, naturally fertile in other parts of the world, tend not to be so in Australia because the primary sources of the alluvium are nutrient poor themselves. Another consequence of the Australian biophysical environment is that soils have low organic-matter contents. This is certainly the case in areas formerly covered with open woodland, and even the small areas of rainforest in northern Australia have much lower organic-matter content in the soil than elsewhere on Earth. The only naturally fertile soils tend to have formed on younger volcanic rocks, and this is why basalt soils of the Newer Volcanic Group in Victoria (Chapter 2) were sought after and settled on (Figure 5.20). European settlers in Australia thus had much less advantage in terms of soils than they did in other places, such as North America.

European settlement brought a dramatic increase in the human impact on Australia's soils. For example, many areas in the Sydney Basin have lost at least $50 \mathrm{~cm}$ of topsoil in the past 200 years. This is a large loss for an original soil that is only $1 \mathrm{~m}$ thick (Box 5.4). The spread of cropping and grazing using European techniques led to a phenomenon known as post-settlement alluvium. Most streams and rivers in the agricultural parts of Australia have a former floodplain surface covered with up to $1 \mathrm{~m}$ of modern alluvium that can be dated to the period following settlement and development of their catchments. The post-settlement alluvium often has European artefacts such as glass bottles and fence wire buried within it. In the Dundas Tablelands of Victoria, this is particularly marked, with bodies of alluvial sediment still making their way down rivers such as the Glenelg (Figure 5.21).

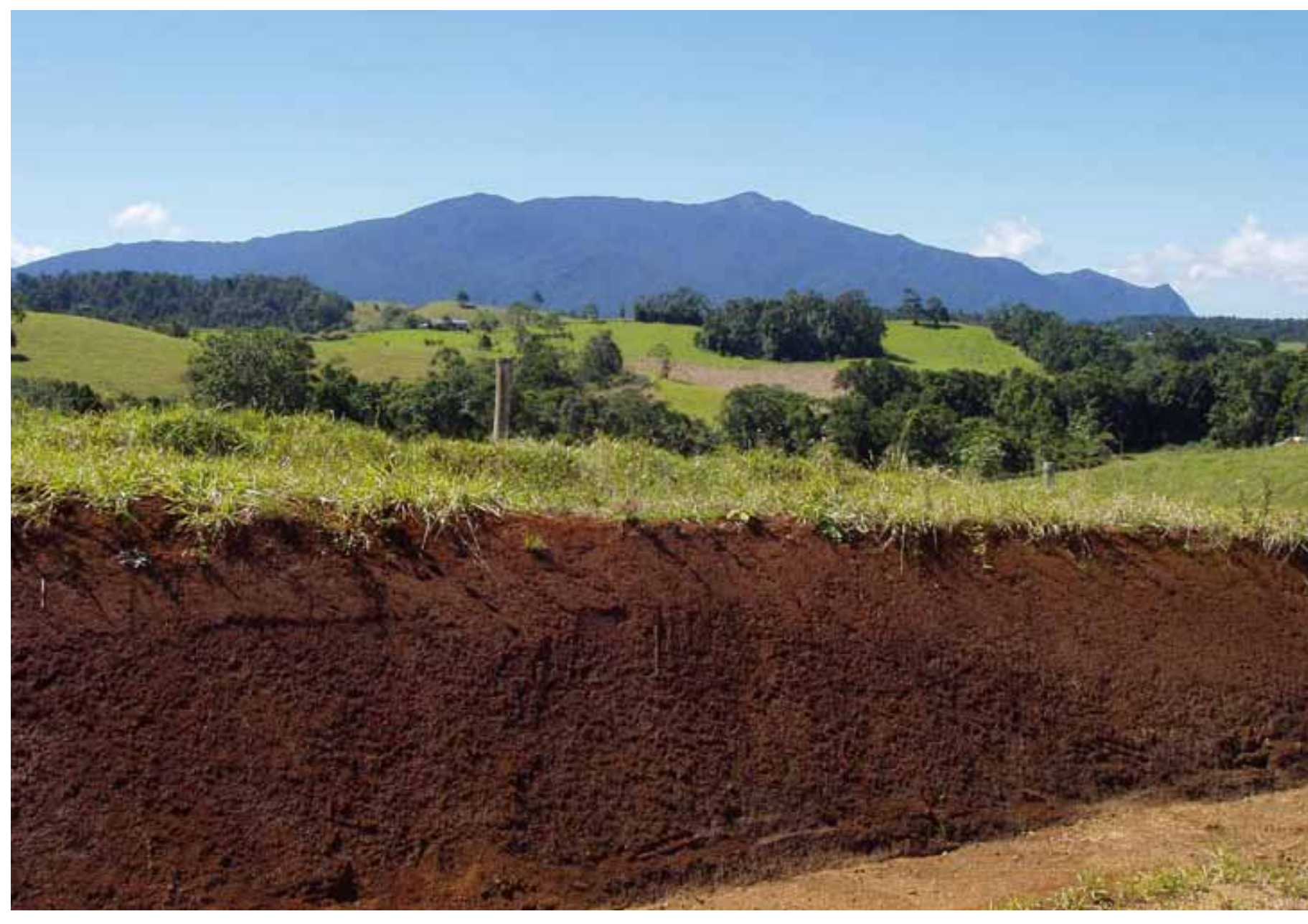

Australia is a very salty continent. Salt is continuously added to Australian agricultural soils from salt-laden rains-for example, in Canberra, the average salt addition is about $30 \mathrm{~g} / \mathrm{ha} /$ year. A change in vegetation from open woodland with deep-rooted trees to shallow-rooted crops and grasses (Figure 1.10) led to a rise in the level of the natural water-table. Rising water-tables resulted in a reduction in the removal of salt from the surface to depth in many landscapes in both western and eastern Australia. The build-up of salt at the surface is called dryland salinity.
Figure 5.20: Soils formed on Cenozoic basalt of the Atherton Tablelands, north Queensland. These are highly productive soils suitable for agriculture, including dairying and tea-growing. 


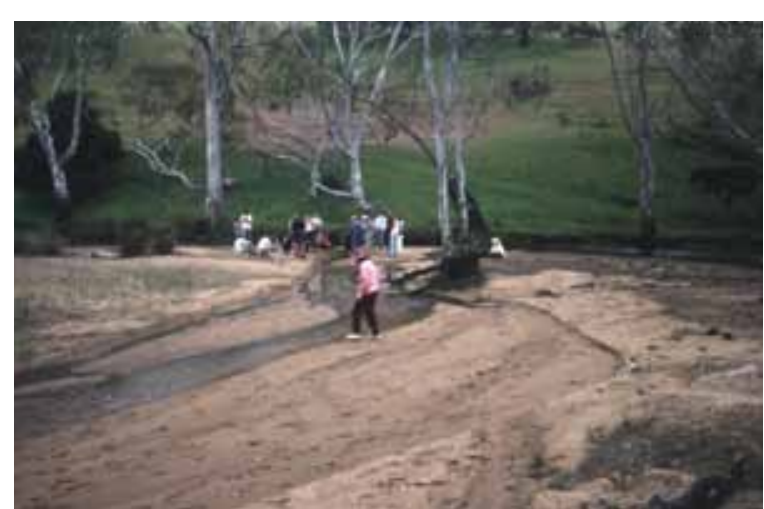

Figure 5.21: A body of sediment from post-settlement erosion moving down the Glenelg River in Victoria.
Ironically, this process is most active in good years; droughts in the 2000s led to a decrease in dryland salinity. However, the same droughts led to the accumulation of salts on floodplains such as that of the Murray River and, with a return to higher rainfall and river flows, this salt may well find its way into the Murray River and thence into Adelaide's water supply (Chapter 7).

Australia's salinity is exacerbated by the low-gradient rivers and internal drainage that are so characteristic of flat landscapes. The rivers are ineffective in removing salt from the continent, and thus there tends to be an accumulation of salt as well as sediments. This is compounded by the fact that the salt is redistributed back to the eastern highlands as aeolian dust carried by winds from the west. One of the perceptions about inland Australia is that it should be capable of supporting a flourishing agricultural industry if only there was enough water. There is water along the coastal strip and also at depth in the interior's groundwater (Chapter 7). This desire has led to many schemes to turn coastal rivers inland, and 'green the desert'. However, with the exception of the Snowy Mountains Hydroelectric Scheme, these plans have largely failed.

Rivers have, nevertheless, been tamed in other ways. The Murray River is one of the most regulated in the world, with four storage dams and 26 locks, weirs or barrages regulating river flow. Another example is the Balonne River in southern Queensland (Figure 5.1), where large amounts of water are diverted into storage in order to irrigate cotton. All these schemes are controversial, and all reflect a desire to try to overcome the geological impact of the long-term evolution of the Australian continent. Griffith Taylor (foundation Professor of Geography, Sydney University) famously concluded that a large part of central Australia was 'almost useless'.

\section{How old is the Australian landscape?}

Australia is often described as an ancient continent, a description that applies to many of its rocks and also its landscapes. The landscapes of today, however, are being shaped by modern weathering, erosional and depositional processes, so when we refer to ancient landscapes we really mean that they have ancient origins. In many parts of Australia, the relative tectonic stability, low relief, lack of Quaternary glaciation, low rainfall and resistant rocks are the combined factors that contribute to low erosion rates. As such, Australia's modern landscapes preserve much of their past history and origin, more so than in many other parts of the world.

The oldest known land surface and the oldest evidence for geomorphological (landscape forming) processes in the world is exposed near Strelley Pool in the Pilbara. At this location, there is angular unconformity between the older Panorama Formation and the Strelley Pool Formation. The unconformity represents a hiatus in volcanic activity between ca $3427 \mathrm{Ma}$ and $3350 \mathrm{Ma}$. The unconformity cuts across volcanic and hydrothermal rocks of the Panorama Formation (Figure 2.22b). These rocks probably formed part of a rocky coastline, with the basal sands and gravels of the Strelley Pool Formation deposited 
later on a gravel beach. The beach deposit is then succeeded by organic stromatolitic carbonates, laid down by a transgressive sea.

Although the Strelley Pool exposure provides a fascinating insight into the nature of an Archean landscape, elements of that landscape have not persisted into the landscape of modern Australia. Palaeogeographic reconstructions indicate that parts of the Australian continent have been subaerially exposed for hundreds of millions of years (Table 5.3), and some areas in the west and north may have been exposed since the Precambrian, more than 500 Myr. So, are there relict landforms that have survived for hundreds of millions of years in these long-exposed landscapes? The answer is 'yes', as the following examples illustrate:

- The Kimberley Plateau in northwest Western Australia is an erosion surface cut across gently dipping sandstones. On softer rocks, valleys were incised below the main plateau level. The Precambrian Sturtian Glaciation occurred around $650 \mathrm{Ma}$, after the main plateau had been created, leaving telltale glacial scour marks on the sandstones and patches of glacial till in the valleys. Possibly, no Phanerozoic sediments ever covered the plateau, and the present landform may be traced to the Precambrian. However, apatite fission-track thermochronology suggests that this landform was once buried and subsequently exhumed (Box 5.5).

- The Jenolan Caves, near Sydney, contain volcanic sediments that were washed in by the sea during the Carboniferous Period, about $345 \mathrm{Ma}$, indicating that the caves were 'open' at that time.
- Relicts of Permian glaciation are widespread in every state of Australia, including well-preserved glacially striated pavements, glacial erratics, diamictites and ice-rafted dropstones. At Hallett Cove, a popular beach and geoheritage site in the southern suburbs of Adelaide, large Permian glacial erratics sit on the modern beach-face.

- Deeply weathered saprolite of Late Paleozoic and Mesozoic age has been identified in many parts of Australia, based on palaeomagnetic dating of oxidised samples and oxygen isotope analyses of kaolinite clays. Late Cretaceous to Oligocene sediments in the Gippsland Basin are dominated by quartz and kaolinite, consistent with stripping of a deeply weathered regolith from the adjacent granitic terrain. Higher atmospheric $\mathrm{CO}_{2}$ levels, combined with higher rainfall and rainforest vegetation, may have promoted the deep weathering of deep granitic saprolites, which were then eroded to provide the sedimentary detritus.

- Uluru is probably the most famous landform in Australia, but its history is tricky to determine. This large erosional feature is composed of steeply dipping arkosic sandstone of Cambrian age and stands some $348 \mathrm{~m}$ above the surrounding plain. The rocks were tilted, folded and faulted during a succession of contractional events associated with the Alice Springs Orogeny (450-320 Ma), and the area has probably remained above sea-level since that time. Late Cretaceous pollen has been recovered from beneath the surrounding plain of Uluru, indicating that the monolith was high ground by that time (ca $70 \mathrm{Ma})$.

\section{Did know?}

\section{2: The Pilbara landscape is out of this world!}

NASA and the Mars Society of Australia view the remote Pilbara of Western Australia as a possible analogue for the Martian landscape. The Pilbara's harsh, arid environment, stony outcrops with their Fe-rich patina, and fossil evidence for very early life (Chapter 3) are part of the attraction for budding astronauts to test their equipment for future missions to Mars.

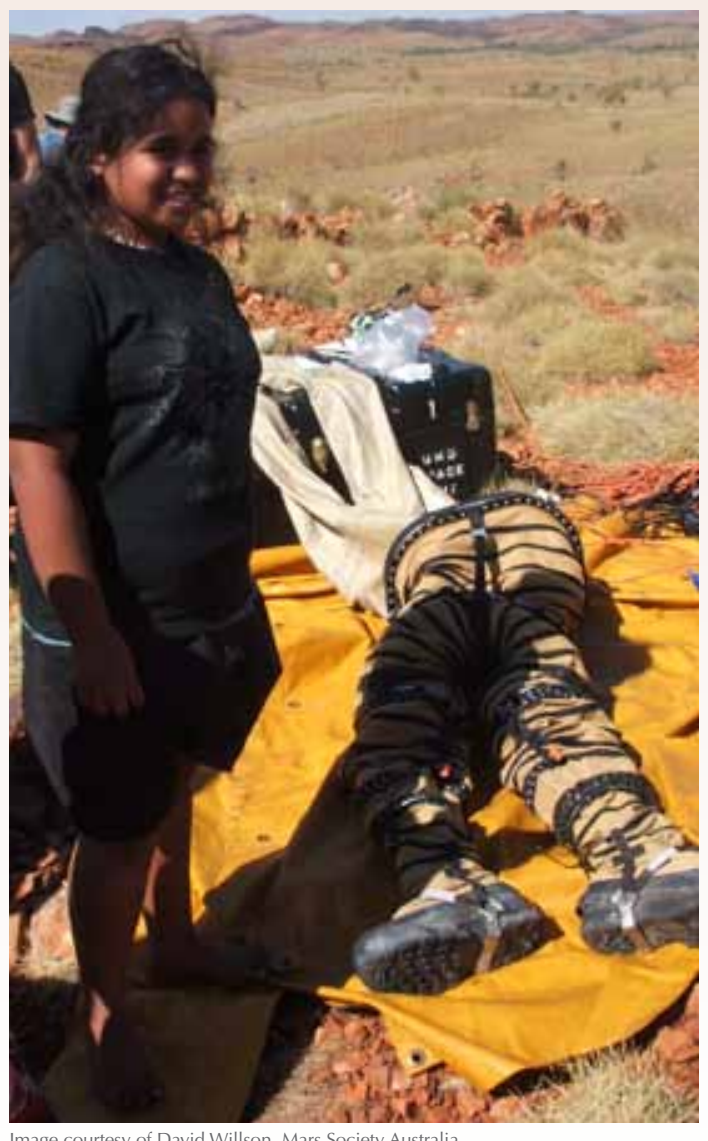

Testing models of potential Mars suits in Australia. 
- The 'gibber' or stony deserts of central Australia are Australia's oldest arid landforms (Figure 5.4). They are characterised by a surface layer of siliceous pebble- to cobble-sized clasts (as the actual gibbers). Cosmogenic nuclide dating shows that gibber pavements west of Lake Eyre were formed between $2 \mathrm{Ma}$ and $4 \mathrm{Ma}$. In contrast, other characteristic arid landforms, such as sand dunes and salt lakes, may be no older than about $1 \mathrm{Ma}$.

- Unlike Northern Hemisphere continents, Pleistocene glaciation was of limited extent in Australia, confined to a few square kilometres on and around Mt Kosciuszko, and more extensive in central and western Tasmania. Lake St Clair in Tasmania (Figure 5.1), which was scoured by ice during the Last Glaciation about $20 \mathrm{ka}$, is Australia's deepest lake ( $c a 190 \mathrm{~m}$ ). The lack of extensive Pleistocene glaciation is one reason why the Australian regolith is so deep compared with the Northern Hemisphere, where large ice sheets scraped off and mixed much of the pre-Pleistocene regolith.

The ages of some well-known Australian landforms are collated in Table 5.3.
Table 5.3: Ages of some well-known Australian landforms

\begin{tabular}{|c|c|c|c|}
\hline Landform & Bedrock age & Landform age & Dating method \\
\hline Jenolan Caves & $\begin{array}{l}\text { Jenolan limestone } \\
\text { (Upper Silurian) }\end{array}$ & Carboniferous (340 Ma) & $\begin{array}{l}\text { K/Ar } \\
\text { Fission track }\end{array}$ \\
\hline $\begin{array}{l}\text { Glacial striations \& erratics, } \\
\text { Hallett Cove, Adelaide }\end{array}$ & Proterozoic & Permian & $\begin{array}{l}\text { Biostratigraphy } \\
\text { Regional geology }\end{array}$ \\
\hline Gosses Bluff & Cambrian-Devonian & $143 \mathrm{Ma}$ & $\mathrm{Ar} / \mathrm{Ar}$ \\
\hline Great Escarpment & Paleozoic & Cretaceous (80-90 Ma) & Seafloor magnetic anomalies \\
\hline Mt Kosciuszko & Paleozoic & Late Mesozoic? & $\begin{array}{l}\text { Fission track } \\
\text { Marginal basin history }\end{array}$ \\
\hline Uluru & Cambrian sandstone & $>70 \mathrm{Ma}$ & Pollen \\
\hline The Breakaways & Cretaceous & Cenozoic & $\begin{array}{l}\text { Pollen } \\
\text { Palaeomagnetism }\end{array}$ \\
\hline Nullarbor Plain & Cenozoic limestone & Eocene & Marine fossils \\
\hline Bungle Bungle Range & Devonian & Miocene? & Regional geology \\
\hline The Three Sisters & Triassic sandstone & $<15 \mathrm{Ma}$ & $\begin{array}{l}\text { K/Ar } \\
\text { Regional geology }\end{array}$ \\
\hline Lord Howe Island & Miocene & Miocene & $\mathrm{K} / \mathrm{Ar}$ \\
\hline Lake George & Ordovician-Silurian & Late Miocene-Pliocene & $\begin{array}{l}\text { Pollen } \\
\text { Palaeomagnetism }\end{array}$ \\
\hline Simpson Desert gibbers & Cenozoic & Pliocene (2-4 Ma) & Cosmogenic nuclides \\
\hline Simpson Desert linear dunes & Cenozoic & Pleistocene (1 Ma) & $\begin{array}{l}\text { Luminescence } \\
\text { Cosmogenic nuclides }\end{array}$ \\
\hline Lake Eyre & Cenozoic & Pleistocene & $\begin{array}{l}\text { Radiocarbon } \\
\text { Luminescence }\end{array}$ \\
\hline Lake Mungo & Pleistocene & Pleistocene & $\begin{array}{l}\text { Radiocarbon } \\
\text { Luminescence }\end{array}$ \\
\hline Lake St Clair & Paleozoic-Mesozoic & Pleistocene & $\begin{array}{l}\text { Radiocarbon } \\
\text { Cosmogenic nuclides }\end{array}$ \\
\hline Undara lava tubes & Pleistocene & Pleistocene (0.19 Ma) & $\mathrm{K} / \mathrm{Ar}$ \\
\hline Great Barrier Reef & Pleistocene & Pleistocene-Holocene & $\begin{array}{l}\text { Sr isotopes } \\
\text { Palaeomagnetism } \\
\text { Radiocarbon }\end{array}$ \\
\hline Mt Gambier & Pleistocene & Pleistocene-Holocene & $\begin{array}{l}\text { Radiocarbon } \\
\text { Luminescence }\end{array}$ \\
\hline Twelve Apostles & Miocene limestone & Holocene & Global sea-level curve \\
\hline Bondi Beach & Triassic & Holocene & Global sea-level curve \\
\hline
\end{tabular}


A large array of modern dating methods underpin our knowledge of landscape evolution in Australia, ranging from methods such as radiocarbon, which measures ages up to $60 \mathrm{kyr}$, to methods such as $\mathrm{Ar} / \mathrm{Ar}$ that can measure ages up to and beyond the age of Earth (Figure B5.5). Each method uses different materials for dating, so no one method is applicable in all situations. Furthermore, many landforms are erosional features, so how do we date what is missing? Fortunately, no landscape is completely erosional, and there will always be materials and features that can be dated to at least partially reconstruct the landscape history.

Interestingly, two methods can actually be used to directly measure erosion ratescosmogenic nuclides and apatite fission-track thermochronology (AFT). The former relies on the balance between nuclide production and erosional loss in surface rocks, while the latter relies on the relationship between fission-track production (from ${ }^{238} \mathrm{U}$ fission-age) and thermal annealing of tracks with increasing depth (temperature). a.

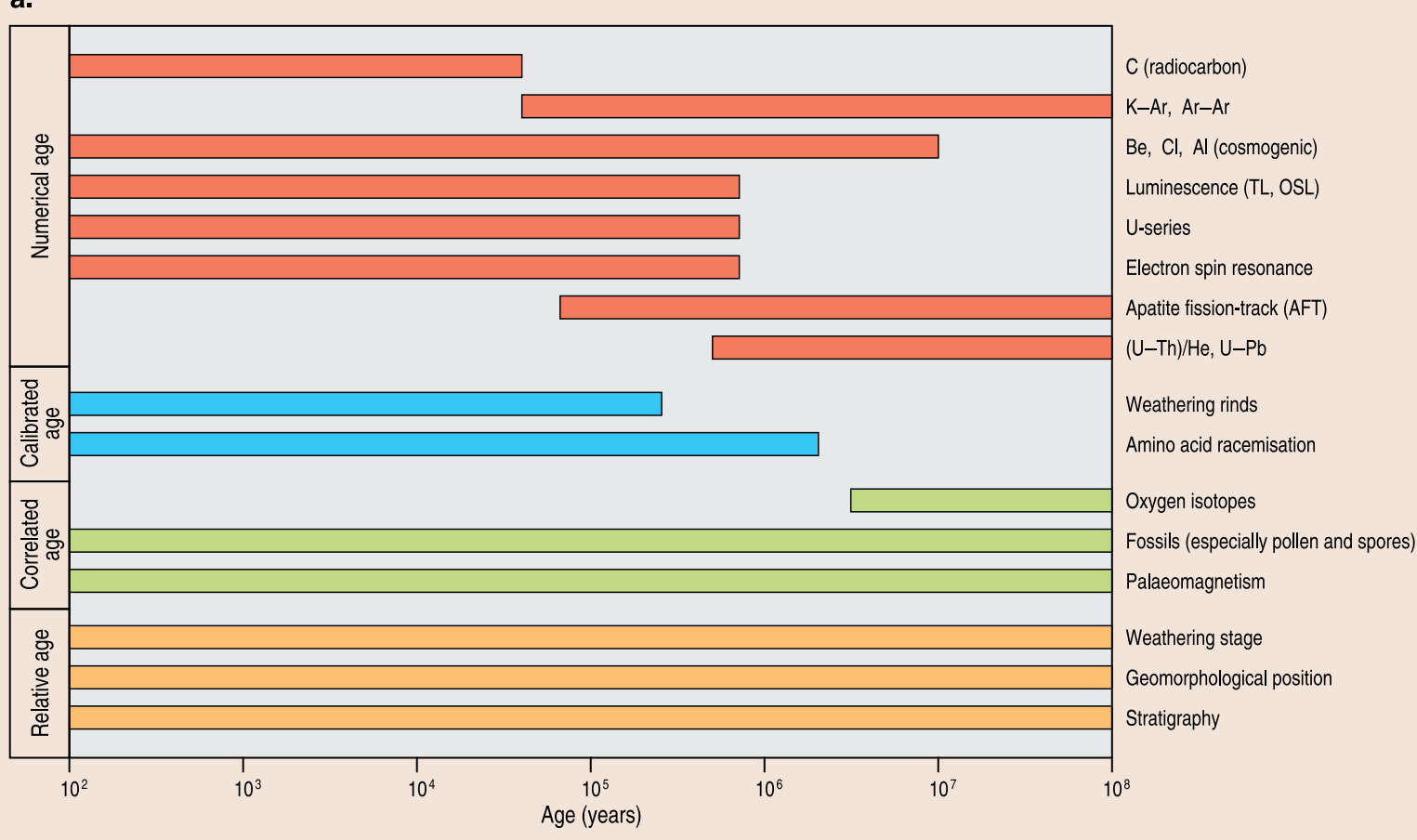

Figure B5.5: (a) Various techniques are available for dating regolith materials and landscapes. The techniques vary in their range, from hundreds to thousands of years to hundreds of millions of years. (b) Maximum duration of continuous subaerial exposure. (Source: Scott \& Pain, 2008)

$\mathrm{OSL}=$ optically stimulated luminescence $; \mathrm{TL}=$ thermoluminescence
Several independent dating methods have been used to demonstrate that ancient (pre-Cenozoic) regolith and landforms are preserved in modern landscapes around Australia. These include palaeomagnetism (iron oxides), oxygen isotopes (clays), $\mathrm{Ar}-\mathrm{Ar}$ (K-bearing $\mathrm{Mn}$ oxides) and biostratigraphy (pollen- and sporebearing sediments). Other methods, such as $(\mathrm{U}-\mathrm{Th}) / \mathrm{He}$ and $\mathrm{U}-\mathrm{Pb}$, also show promise for dating pre-Cenozoic regolith, but have yet to be applied to suitable materials.

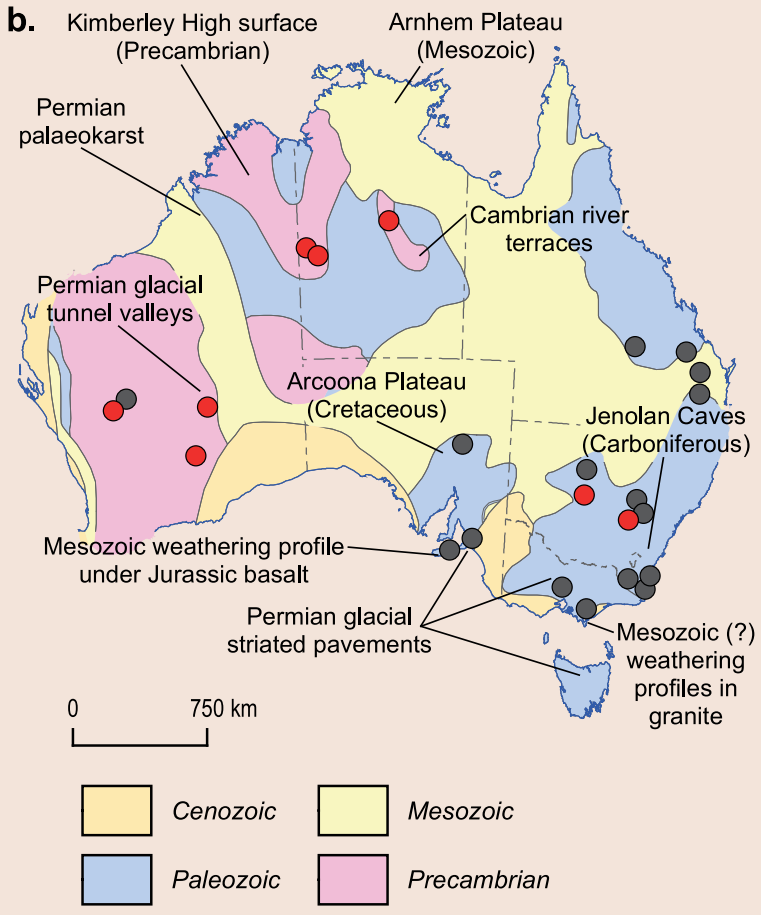

- Mesozoic clays (oxygen isotopes)

- Pre-Cenozoic deep oxidation (palaeomagnetism) 


\section{How regolith enriches Australia}

Resources from the regolith have enriched the lives of Australians. Australia no longer rides on the sheep's back (also based on a regolith resource, when you think about it) but is now reliant on bulk commodities to fill out its balance sheet. Nevertheless, a glass of shiraz, grown in Australian regolith, is a lot more palatable than an orebody (Box 5.6).

The bulk commodities represent a substantial proportion of Australia's exports-more than $42 \%$ in 2008-09-and many of those are actually obtained fully or partially from the regolith (Chapter 9). They include bauxite, alumina and aluminium; ilmenite, rutile, leucoxene and zircon; iron ore and steel; $\mathrm{Mn}$ ore; nickel $(\mathrm{Ni})$ laterite ore; magnesite; and, to some extent, gold $(\mathrm{Au})$ and uranium (U). Coal could also be considered a palaeo-regolith resource. In fact, many ore deposits are affected by, or have been upgraded by, regolith processes in some way, through weathering, supergene enrichment, sorting and winnowing, but let's not stretch the analogy too far.

Since the first people occupied Australia more than $50 \mathrm{ka}$, regolith materials have been the focus of mining activities. Aboriginal people mined ochre and clay deposits for artistic and ceremonial purposes, and rock outcrops for materials to manufacture cutting, pounding and grinding tools. Mining is known to have occurred at hundreds of localities, but some of the most notable operations were at Koonalda in South Australia, and at Wilgie Mai, southeast of Geraldton in Western

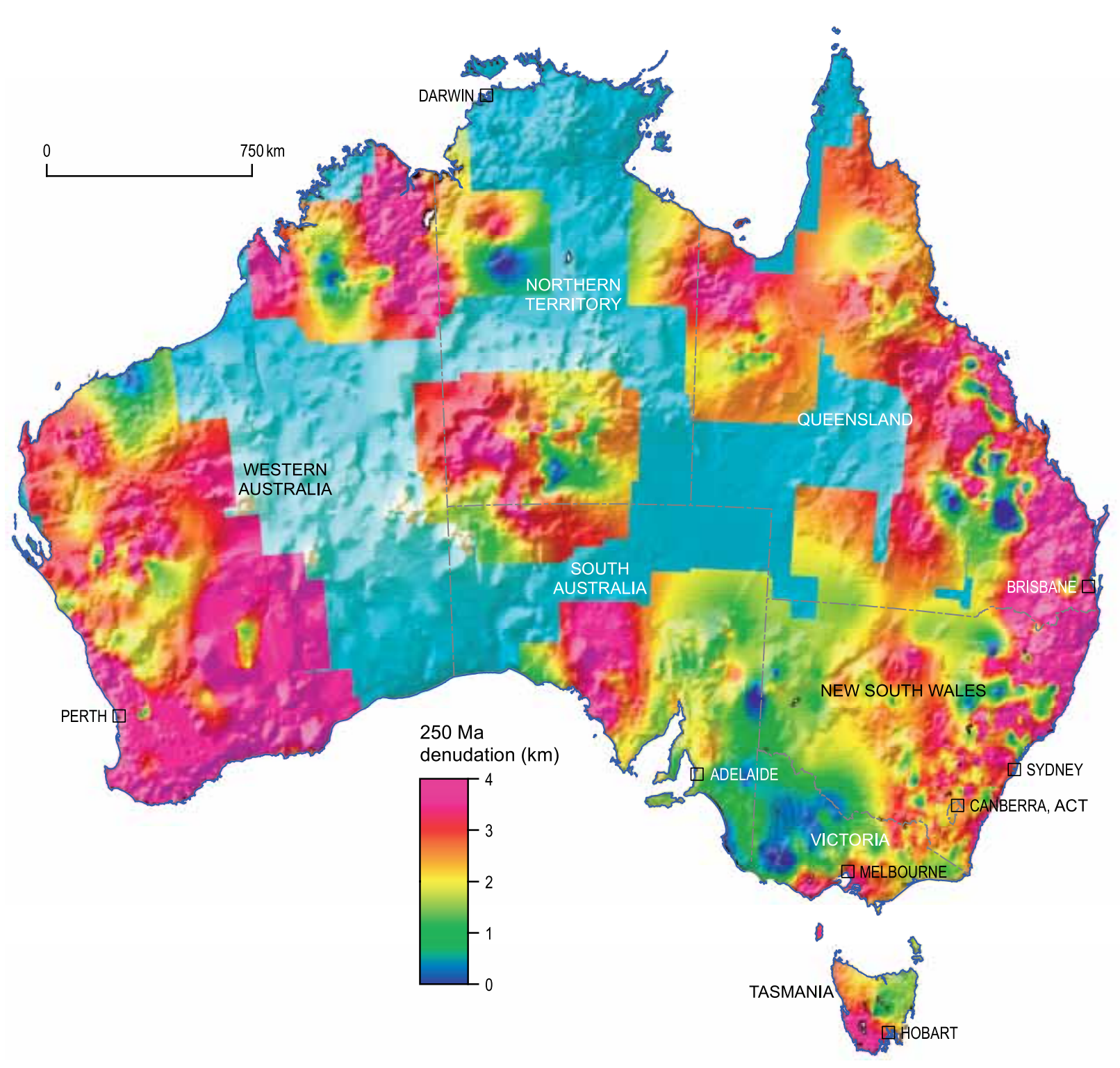

Figure 5.23: Denudation of Australia over the past $250 \mathrm{Myr}$, based on apatite fission-track thermochronology. Blue regions are areas of no data. These data suggest that large areas of the Yilgarn Craton in southwest Western Australia have been eroded by around $4 \mathrm{~km}$. (Source: Kohn et al., 2002) 


\section{- FLAVOURED WATER IN A FRUIT BAG (воx 5.6)}

Grapes are small bags of sweet-and-sour water. The water comes through the roots of the vine, whereas the flavour is influenced by the mineral and organic composition of the soil (regolith). Terroir is the French term for earth, but to a viticulturalist it means a combination of the vine variety, chemical and physical attributes of the soil and rock (regolith), slope, aspect, drainage and microclimate. Differing terroir leads to differing wine characteristics.

The world of wine is divided into Old World (traditional Europe) and New World (the rest). One characteristic of New World wines is that most grapes are grown in hotter climates than the more temperate Old World, which means shorter hang times. In the New World, grapes have longer growing seasons and tend to be riper, creating wines that are fuller and have more body and higher alcohol content. Australian wines are New World. They were once dismissed by traditionalists, but for the past few decades have been winning many top international wine competitions.

Australia's primary wine grapes are shiraz, chardonnay, and cabernet sauvignon. Australia sustains more than 1100 wineries in 26 different wine regions. Being such a large country with almost every climate and soil type, Australia is one of the few wine producers to make every one of the major wine styles. Wine exports amounted to more than $\$ 2.172 \mathrm{~B}$ in 2009-10.
One of the leading wine-growing areas is the McLaren Vale, located around $30 \mathrm{~km}$ south of Adelaide in South Australia. This wine region comprises two triangular-shaped basins, with the vines growing in seven distinct 'terranes' that range in bedrock age from the ca 750 Ma Burra Group to Holocene sands. The region boasts high-class full-bodied red wines. To the north of Adelaide, the Clare Valley's best shiraz and cabernet wines are grown from old vines on thick red-coloured terra rossa loams overlying dolomitic siltstone and slate.

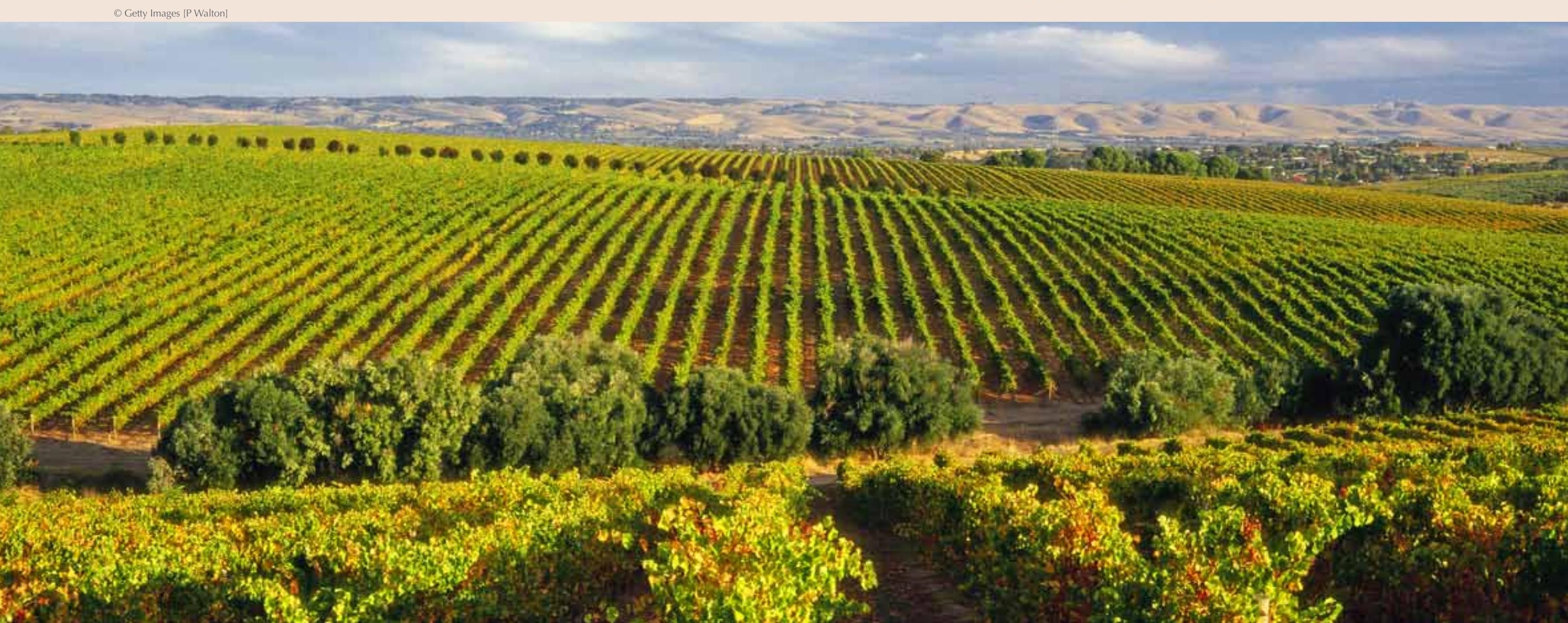


Australia (Figure 5.1). At the Koonalda flint mine, a $300 \mathrm{~m}$-long shaft was driven to a depth of $75 \mathrm{~m}$ from the surface. At the Wilgie Mia ochre mine, a mining face up to $30 \mathrm{~m}$ wide and $15 \mathrm{~m}$ deep was worked with the aid of heavy stone mallets, fire-hardened wooden wedges and wooden pole scaffolding to access the working face. Wilgie Mia may well be the longest continuously mined site in the world. Flint from Koonalda was traded throughout central Australia. Ochre from Wilgie Mia mine was particularly valuable, and may have been traded all the way from Western Australia to Queensland. Ochre from the Yarrakina mine at Parachilna, in the northern Flinders Ranges, was valued for its softness and lustrous qualities. Blocks were traded into the Northern Territory, western Queensland and eastern New South Wales, and are known to have been exchanged for shields and spear shafts.

Mining the regolith continued after the arrival of the First Fleet in January 1788. In March 1788, brick making began at what is now Darling Harbour in Sydney. By May 1788, the site had produced between 20000 and 30000 bricks, which were used to construct buildings, including the first Government House in 1789 and buildings in the Rocks area. The early brick-makers did not have access to a good source of lime to make their mortar, so oyster shells, probably derived from nearby Aboriginal middens, were used to make the mortar for the construction of Government House (Chapter 6).

In addition to the production of bricks and tiles, the clay at the brickfields was used to make pottery, including the then-ubiquitous terracotta pipe,

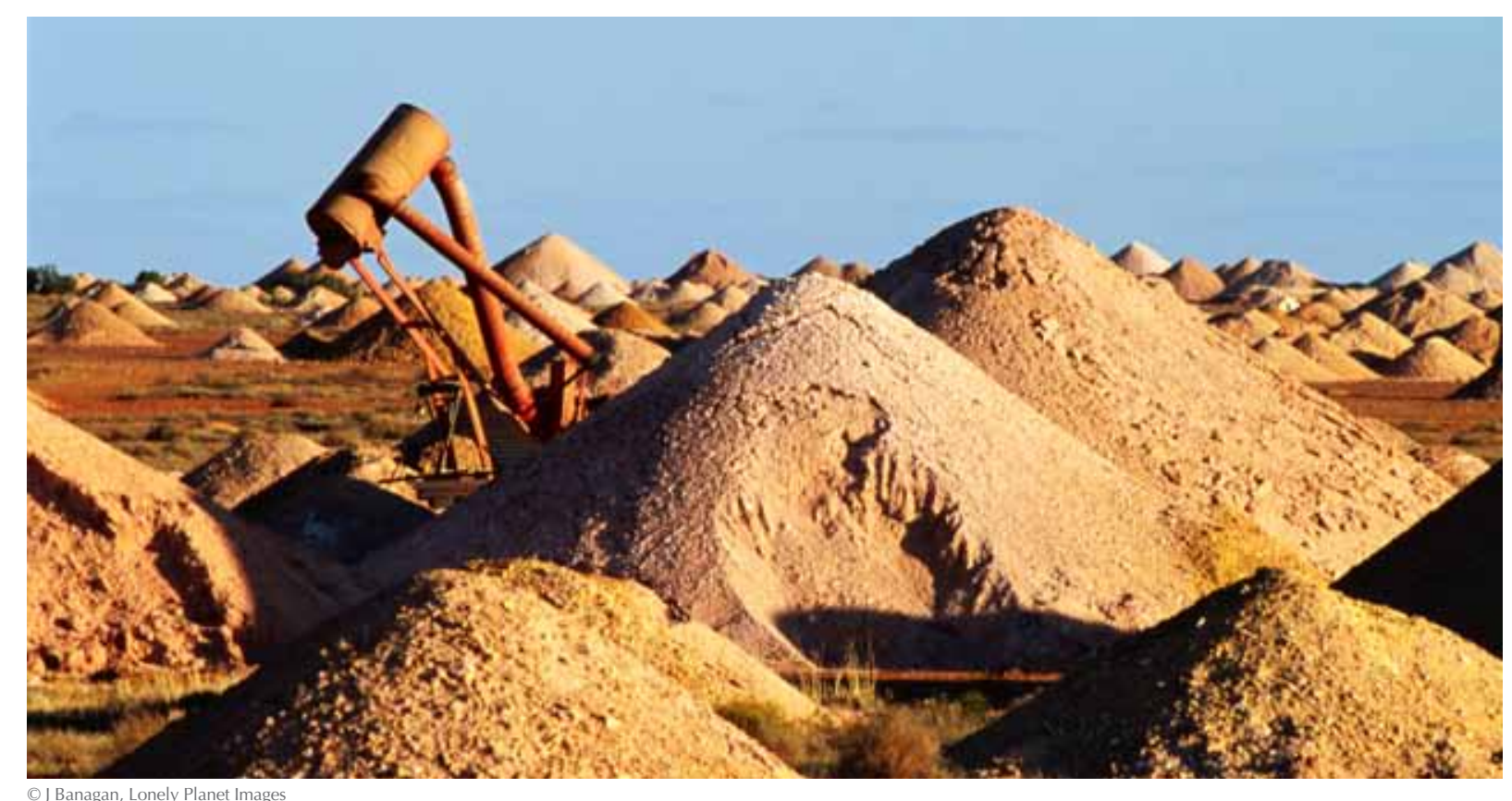

commencing in 1790. As the settlement at Sydney Cove grew, brick-making activity expanded. The surrounding landscape was deforested, as trees were felled to fuel the kilns, and pock-marked by clay pits. The excavation of clay pits and brick-making continued on the perimeter of the settlement and migrated outwards as the settlement expanded; such pits produced some of the first dateable fossils (Chapter 3). The early settlers also experimented with glass making, using sand derived from the white dunes along what became South Head Road.

As Australia developed economically, road-making activities expanded, and construction techniques began to change. The difficulty in obtaining and working with quality aggregate (hard, fresh rock) resulted in many local governments resorting to paving highways and roads with gravel and clay sealer; this is still a common practice. Clay-paved roads reduce dust and are self sealing when damp,
Figure 5.24: Spoil heaps from opal mining at Coober Pedy in South Australia. The harsh climate has meant that many residents of Coober Pedy live underground in the old workings. 


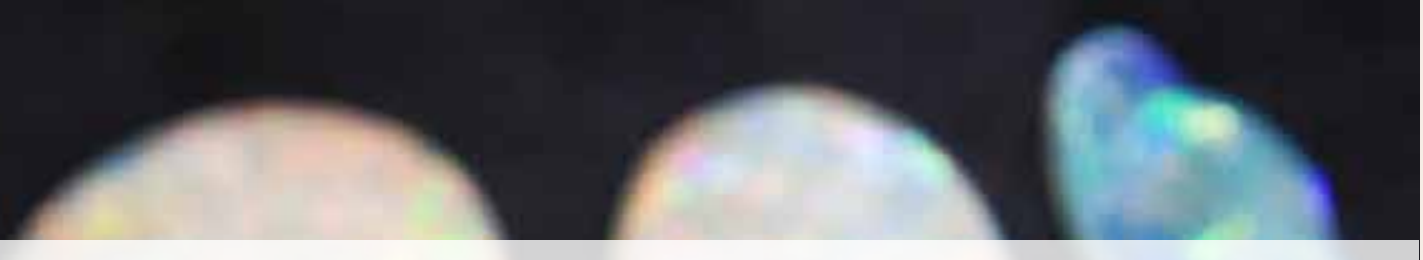

\section{OPAL_AUSTRALIA'S NATIONAL} GEMSTONE (вох 5.7)

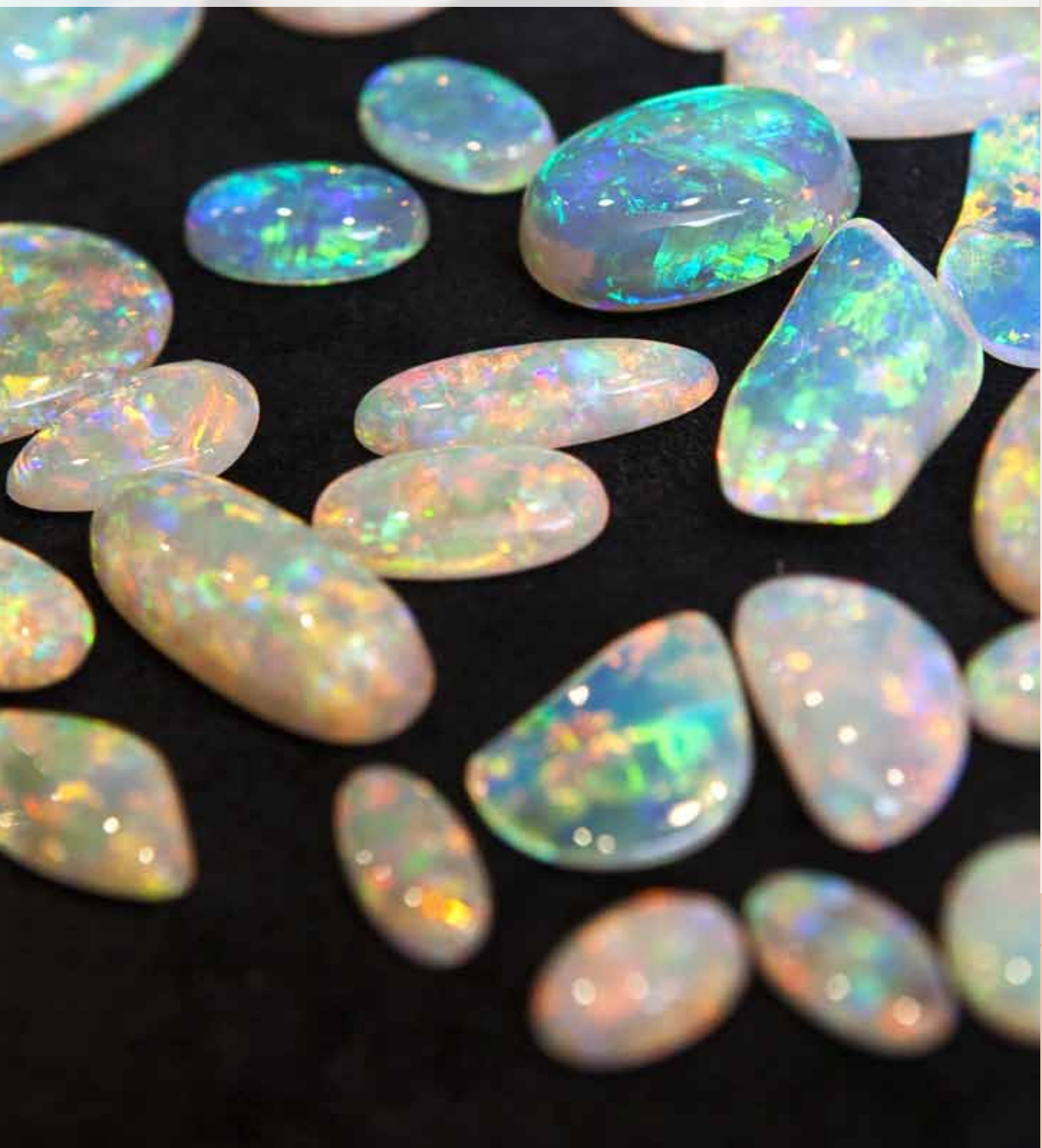

Opal is Australia's national gemstone-more than 95\% of the world's opal comes from Australia, almost all of it from the southern margins of the Great Artesian Basin (Figure B5.7). Opal is chemically similar to quartz, but contains up to $20 \%$ water. The characteristic display of opa colours is produced by the diffraction of light by a regular array of silica spheres that make up the opal. The background colour may be white, grey, blue, black or colourless. A dark background produces 'black' opal, which is the most colourfu and valuable type of opal, almost all of which comes from Lightning Ridge in northern New South Wales. Unlike most other mining sectors in Australia, opal mining is almost entirely done by individuals and family groups, rather than mining companies.

Some overseas opal is volcanic in origin and tends to have abundant inclusions of water, which make the gem brittle. Australian opal, in contrast, was deposited as a replacement mineral from silica-rich groundwater within $25 \mathrm{~m}$ of the surface, particularly in kaolinitic weathering profiles Opal forms close to groundwater permeability barriers, such as within faults, cracks and joints, or replacing soluble minerals or organic materials (e.g. bone, wood or fossil). The famous pliosaur skeleton called 'Eric', from Lightning Ridge, is one such example. Flow structures in some opals indicate an initial aqueous phase, followed by dehydration of a silica gel. The discovery of heritage-listed Lark Quarry dinosaur footprints near Winton in outback Queensland (Chapter 3) was made by opal miners; there the Cretaceous plant rootlets are also opalised.

Opal has been regarded as a stone of good fortune, and it was believed that the gem possessed magical properties. Opal fell out of favour during the late 18th and 19th centuries, as it was associated with pestilence, famine and the fall of monarchies. The type, colour, size and soundness of precious opal are factors that determine the price, which is expressed per carat.

of Sones, Lonely Planet Images 
Opal is hosted in Cenozoic weathering profiles; it has been dated at ca $16 \mathrm{Ma}$ (Miocene) in the Coober Pedy deposits, with several younger opal-forming events. Some opal is very young. Radiocarbon dating of organic material incorporated in the matrix of some black opal from Lightning Ridge has yielded Holocene ages, while partly opalised fence posts have been reported in some places.

The 'fire' in opal also features in Aboriginal Dreamtime stories. The Wangkumara people from around Cooper Creek believe that they were brought the gift of fire from opal. The story goes that the tribe sent a pelican away from their camp to find out about the country up north. The pelican felt ill and landed on a hill. The pelican discovered beautiful opal and started chipping it away to bring back to the people. A spark from the chipping caused the nearby dry grass to catch on fire, which spread slowly back to the camp. This fire was captured by the people to cook their meat (Connolly, 2012).

Opal miners are often 'rugged individuals', some of whom took up a claim in order to strike it rich, but could never leave their new homes because they'd sold all their possessions to cover their 'grubstake'. Other claims are owned and run by families and are handed down through generations; these claims are treated more as a holiday retreat and are only worked during school holidays to earn that 'little bit extra'. At White Cliffs (NSW) and Coober Pedy (SA), many of the citizens live entirely underground. Homes and entire hotels are constructed underground in disused opal mines to provide year-round comfort, escaping the searing summer temperatures in these remote communities. Australia's opal miners are modern-day troglodytes!

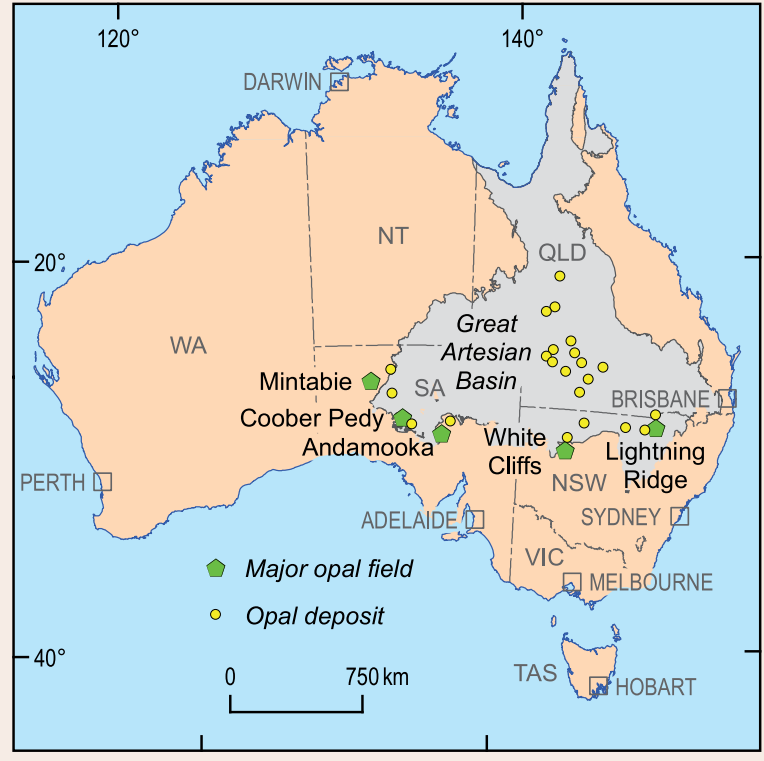

Figure B5.7: Location of the opal fields in Australia; outline of the Great Artesian Basin is also shown (Chapter 7).

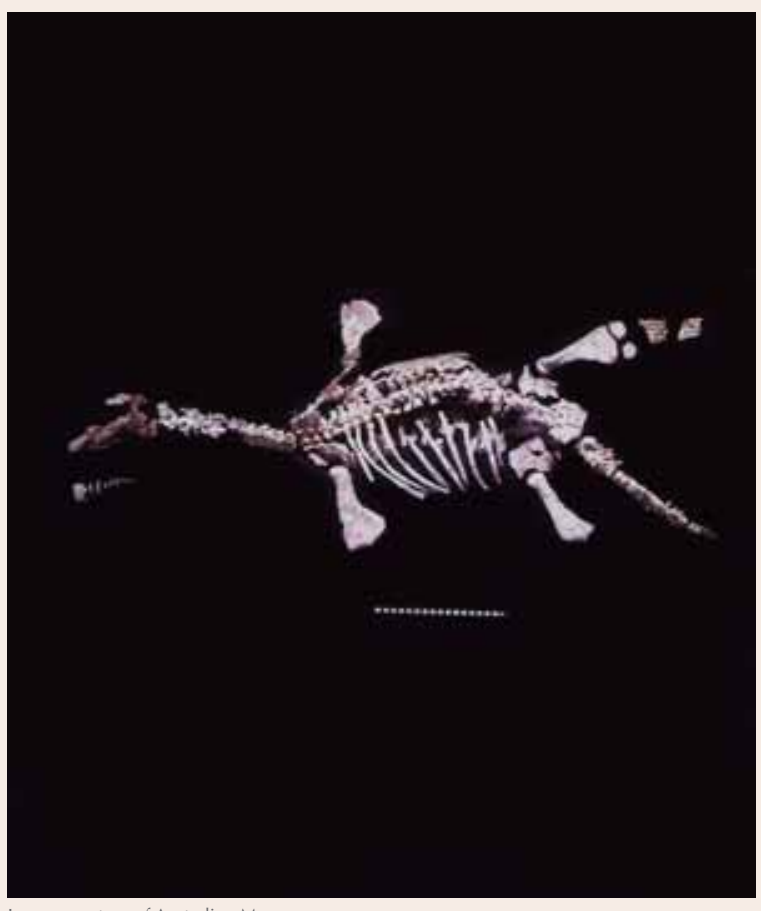

Eric the pliosaur, an opalised skeleton on display at the Australian Museum, Sydney.

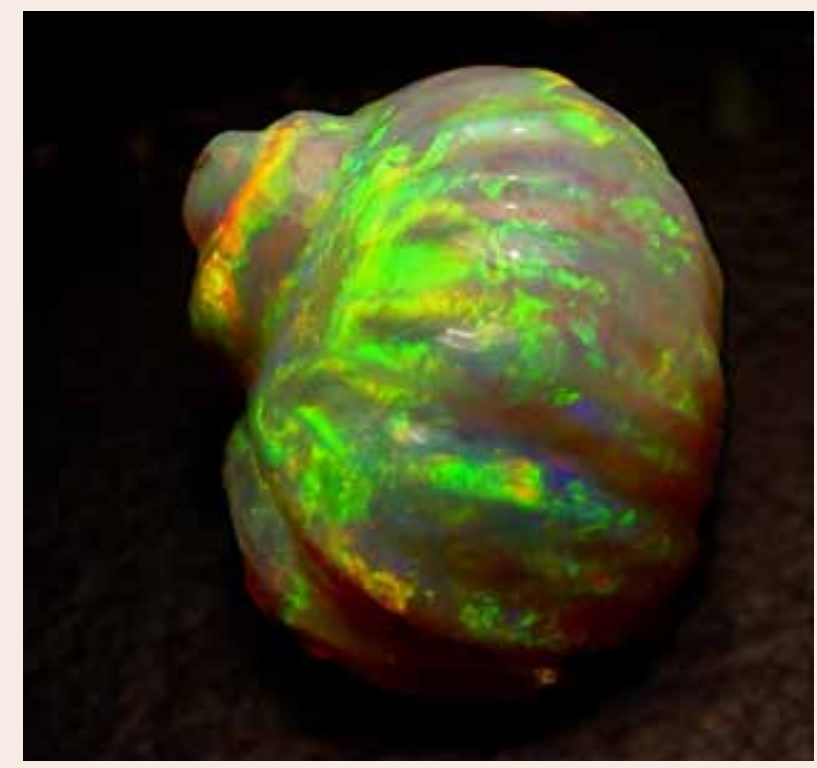

Opalised snail shell.

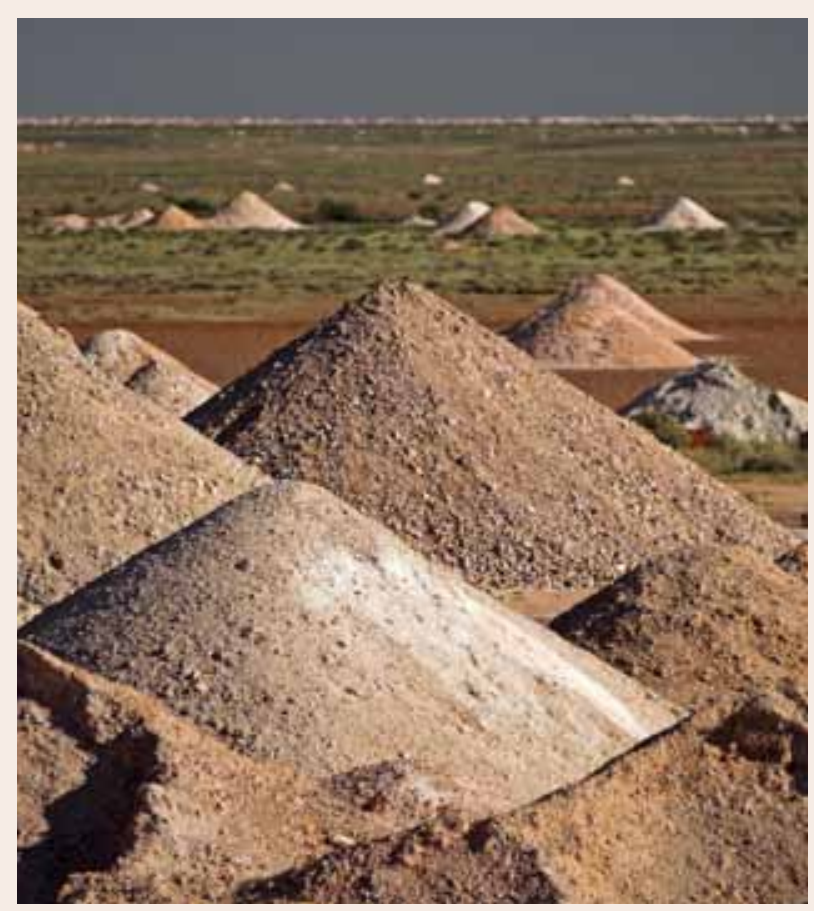

Noodling heaps at an opal mine in Coober Pedy, South Australia. 
Regolith processes play an important role in upgrading subeconomic primary (in-situ) mineral deposits, or creating secondary mineral deposits, such as clay, Au, diamonds, tin, alumina (bauxite), Ni laterite, $\mathrm{Mg}$ (magnesite), iron ore (channel-iron deposits) and U. Many of the bulk commodity deposits mined today may not have been economic without the aid of secondary enrichment by regolith processes. The regolith-governed mineral systems differ from the hydrothermal mineral systems (Chapter 8) in their pressure and temperature, but the essential elements of the two types of system are much the same (Figure 8.4).

In-situ deposits may be enhanced by weathering processes, and it is not uncommon for gold miners to take a rich supergene oxide $\mathrm{Au}$ or $\mathrm{Cu}$ resource for a quick return on investment, but leave sulfides in the ground for later (if ever), because of the extra expense of treating the often-difficult sulfides. Examples come from all over Australia, but particularly the Yilgarn Craton, where supergene $\mathrm{Au}$ in Eocene palaeovalleys has helped many a company out of a tight squeeze when funds were short. Similarly, the giant Broken Hill $\mathrm{Pb}-\mathrm{Zn}-\mathrm{Ag}$ deposit had a thick gossan of secondarily enriched oxide, hydroxide and carbonate ore, some of which still exists at Browns Shaft, above the massive sulfide lodes (Figure 5.25). Broken Hill was often referred to as 'the hill of mullock' by early explorers, who misunderstood the value of the gossan. The gossan was quickly mined and smelted to obtain a fortune in Ag before the more difficult primary ores could be treated with metallurgy using froth flotation, the Australian invention developed at Broken Hill (Chapter 1). (See Figures 2.21a and $2.21 \mathrm{~b}$ for localities of these deposits.)

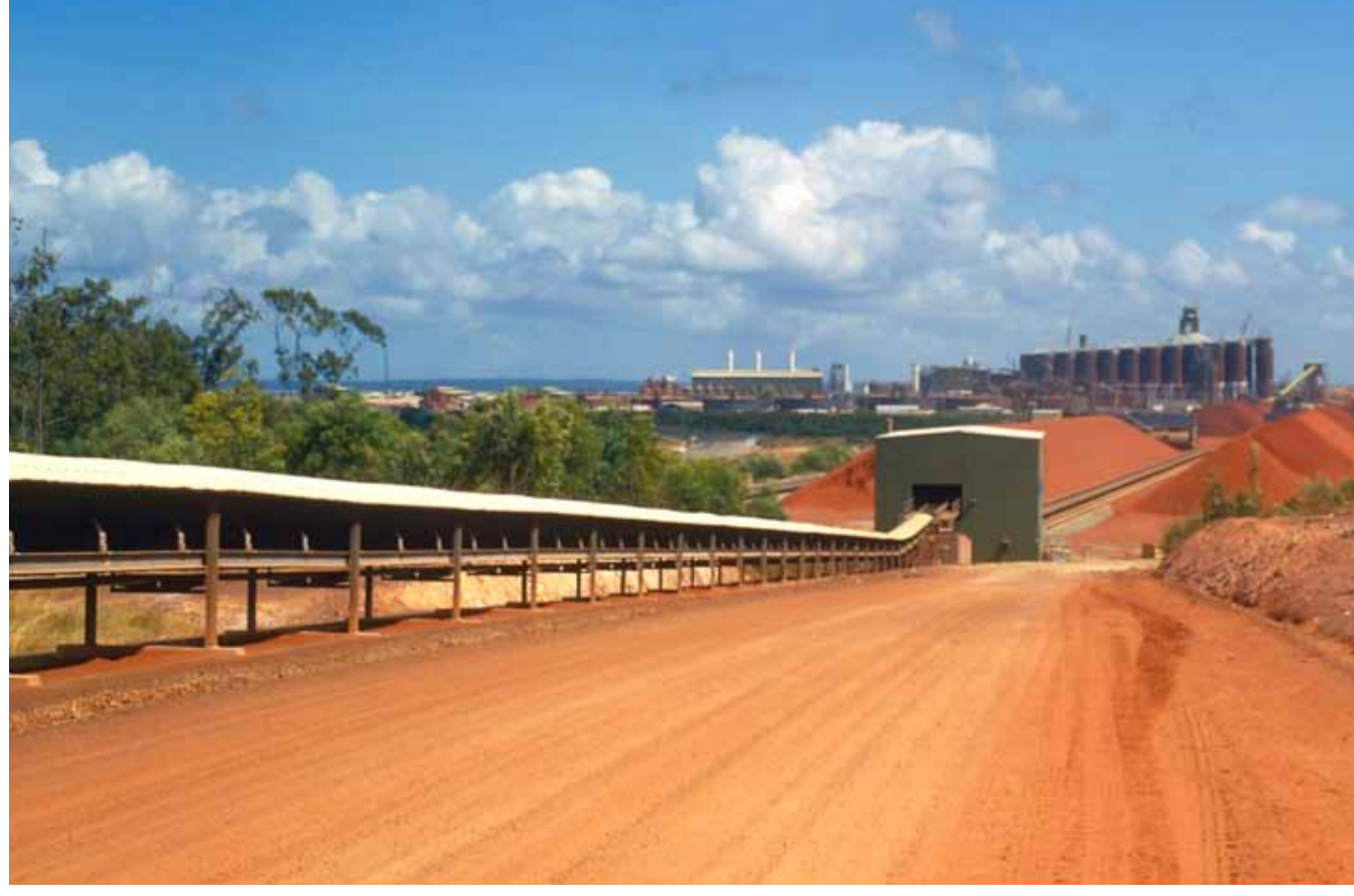

Regolith processes are responsible for the in-situ upgrading of bauxite deposits at Gove (NT) (Figure 5.26) and the Darling Ranges (WA), but also the transport and deposition of bauxite pisoliths at Weipa (Qld). Because of this, Australia has the world's second largest economic demonstrated resources of bauxite, and the world's largest production levels (Chapter 9). Similarly, Pilbara iron ore was enriched in situ to form the direct-to-ship microplaty hematite ore of the Hamersley Basin. High-quality iron ore was formed by sedimentary and groundwater processes such as the channel-iron deposits at Pannawonnica and Robe River (Figure 5.1).
Figure 5.26: Gove, Northern Territory, hosts one of Australia's main bauxite deposits. 
Figure 5.27: In-situ recovery injection and extraction wells and associated pipework at the Pepegoona uranium deposit, near the Beverley uranium mine, South Australia.
Australia also has the world's largest economic demonstrated resources and production levels of zircon, rutile and a number of other minerals that are found in heavy-mineral sand deposits, which formed on modern and fossil beaches as a consequence of coastal processes. Heavy-mineral sand deposits have long been known and exploited in Holocene coastal dunes and barrier islands in Queensland, New South Wales and Western Australia. An improved understanding of mineral sources and depositional palaeo-environments has resulted in many new finds in the Eucla and Murray-Darling basins (Figure 5.10). New understanding of palaeo-longshore drift processes in the Eucla Basin-a Cenozoic coastal barrier system—has resulted in the discovery of numerous rich heavy-mineral sand deposits, including Jacinth and Ambrosia, which alone are estimated to contain a combined $4.5 \mathrm{Mt}$ of zircon, $2.6 \mathrm{Mt}$ of ilmenite and $46 \mathrm{kt}$ of rutile. Similarly, new models of coastal structure and sedimentation in the Loxton-Parilla Sands of the Murray Basin, developed since the 1980s, have brought to light many new heavy-mineral sand deposits; the basin had previously been thought to contain only large, sub-economic fine-grained deposits in Victoria. Advances in remote-sensing technology, particularly night-time thermal satellite imagery and detailed airborne geophysics, have been instrumental in uncovering palaeo-environments and these new deposits.

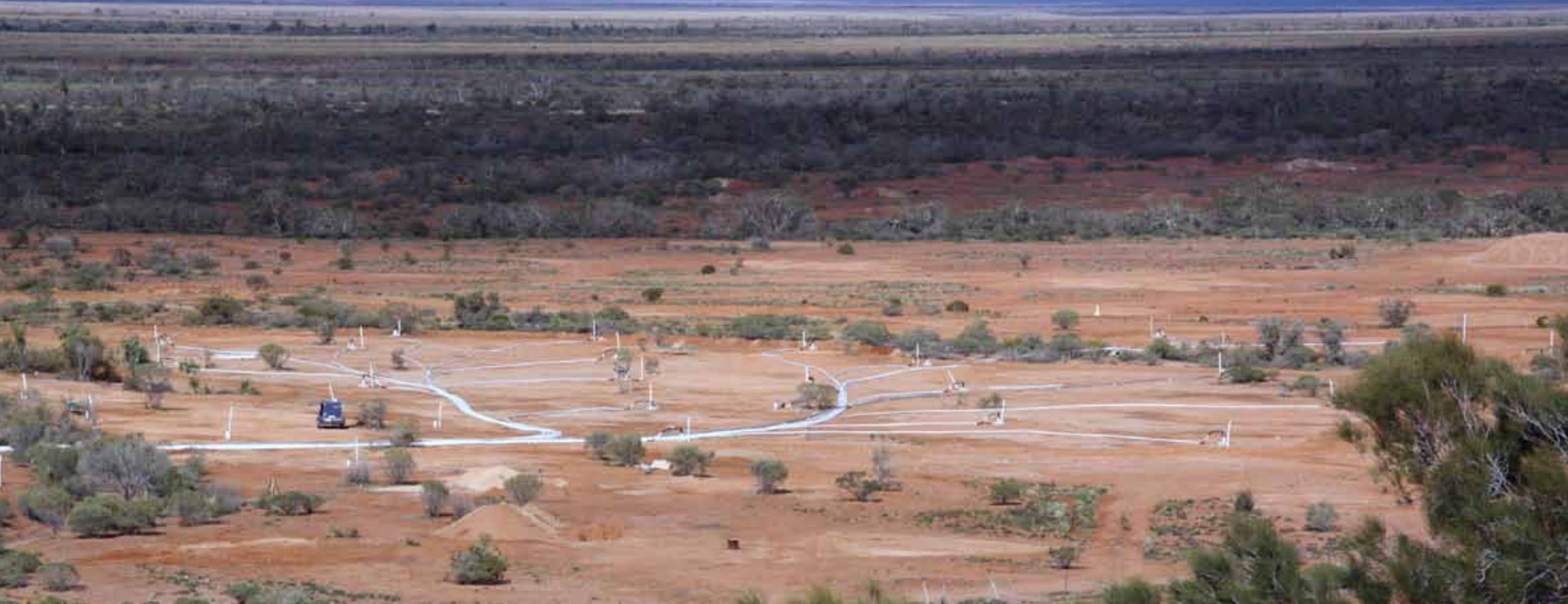


Australia now has four working $\mathrm{U}$ mines, which in order of size, are Olympic Dam (SA), Ranger (NT), Beverley and Honeymoon (SA). Olympic Dam is the world's largest single $\mathrm{U}$ deposit, containing more than $2.557 \mathrm{Mt}$ of $\mathrm{U}_{3} \mathrm{O}_{8}$ in a hard rock deposit also containing a fabulous wealth of $\mathrm{Cu}, \mathrm{Au}$ and $\mathrm{Ag}$ - this is BHP Billiton's crown jewel (Chapter 8). While it would be nice to claim this as a regolith deposit, it is not, nor is Ranger $\left(108000 \mathrm{t}\right.$ of $\left.\mathrm{U}_{3} \mathrm{O}_{8}\right)$. However, the Beverley mine (Figure 5.27) (21000 t of $\mathrm{U}_{3} \mathrm{O}_{8}$ ), and Honeymoon mine (2900 t of $\mathrm{U}_{3} \mathrm{O}_{8}$ ) both in the Frome Embayment (SA), are sandstone-hosted $\mathrm{U}$ deposits formed in Cenozoic palaeovalleys by the concentration of $U$ from groundwater. Numerous similar deposits are now recognised around Beverley, including Four Mile East and Four Mile West (32000 t of $\mathrm{U}_{3} \mathrm{O}_{8}$ combined), Beverley North-Pepegoona (4000 t of $\mathrm{U}_{3} \mathrm{O}_{8}$ ), and the Yadglin and Pannikin deposits. The $U$ mineralogy is dominated by coffinite (U silicate) and uraninite ( $\mathrm{U}$ dioxide).

The realisation that the flat landscape of the Frome Embayment hides Paleogene and Neogene palaeovalleys that contain reductants suitable for fixing $U$ from groundwater has led to further discoveries at Goulds Dam and Oban; exploration continues apace. Numerous other similar deposits have been found-for example, Angela-Pamela, Bigrlyi and Walbiri (NT) and Manyingee, Oobagooma and Mulga Rock (WA). Models for depositing $U$ within the palaeovalleys include the traditional roll-front style, but also the accumulation of organic material in point bars of the palaeorivers, which act as chemical reductants causing $\mathrm{U}$ deposition. No matter the model, $\mathrm{U}$ is fixed and concentrated by a fundamental chemical process in the regolith that involves the precipitation of $U$ from an oxidised fluid on contact with a reductant, whether that is anoxic groundwater, sulfide, hydrocarbon or organic material (Did you know? 5.3). Change in redox is a common process for the deposition of metals in many mineral systems (Chapter 8).

Another important regolith-related $U$ deposit style is that of the calcrete-hosted surficial deposit. $\mathrm{U}$ mineralogy in these types of deposit is dominated by carnotite (U-vanadate), and these deposits occur in areas where calcrete occurs in proximity to source rocks of $U$ and vanadium $(V)$. Typically, the granitegreenstone terranes of the Yilgarn Craton are favoured because the granites leach the $\mathrm{U}$ (Chapter 10), and the greenstones (metamorphosed basalts) leach $\mathrm{V}$, on weathering. A number of deposits or prospects are recognised, mostly in Western Australia, including Yeelirrie (52 $500 \mathrm{t}$ of $\mathrm{U}_{3} \mathrm{O}_{8}$ ), the Wiluna area (Lake Way: $5714 \mathrm{t}$ of $\mathrm{U}_{3} \mathrm{O}_{8}$, and Centipede: $5355 \mathrm{t}$ of $\mathrm{U}_{3} \mathrm{O}_{8}$ ) and Lake Maitland. The deposition of $\mathrm{U}$ in these deposits is not dependent on redox, but instead relies on a change in $\mathrm{pH}$ and an increase in $\mathrm{Ca}, \mathrm{K}$ and $\mathrm{V}$ ion concentration in groundwater by evaporation. This occurs in juxtaposition with calcrete formation in the bottoms of long, wide drainage systems, resulting in carnotite precipitation within the calcrete bodies. Extraction is even easier as the carnotite can be dissolved using heap-leach techniques.

While occasional surprise gossans are still found sticking out of the ground, prospectors appear to have thoroughly worked over most of the rocky

\section{Did know?}

\section{3: Uranium deposition is reversible.}

The element $U$ is relatively cheaply and easily extracted using the in-situ recovery process, whereby the chemical process that precipitated the $U$ minerals in the first place is reversed and the minerals are dissolved by re-oxidising the groundwater. This is achieved by using a weak acid-peroxide solution injected into the ground through a 4-, 5- or 6-injection well pattern and recovered through a central extraction well. Beverley was Australia's first in-situ recovery mine, with Honeymoon following.

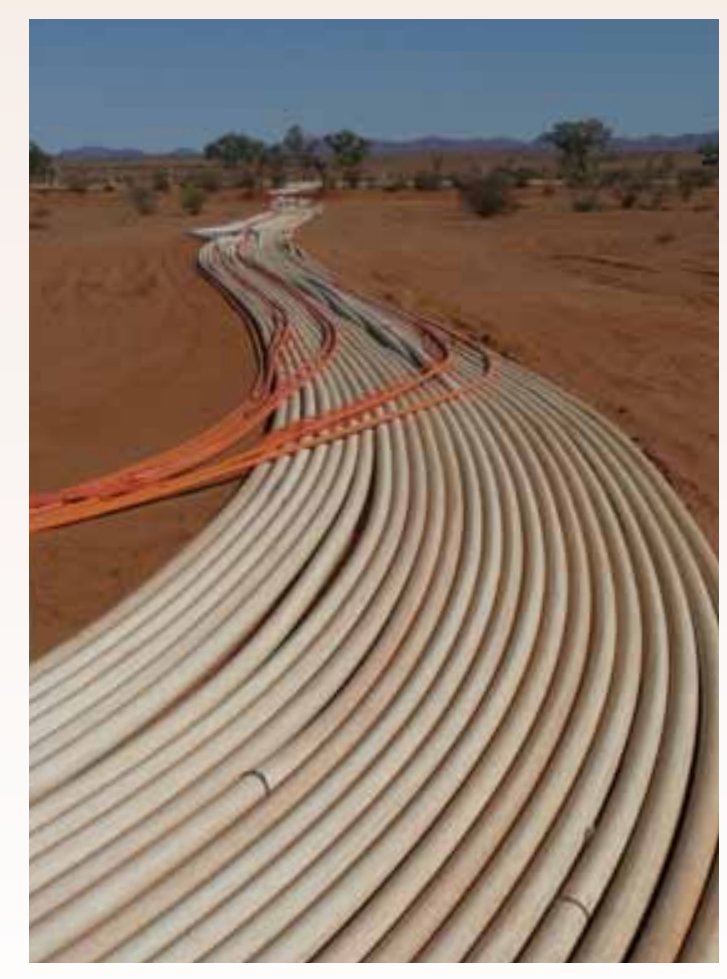

Injection and extraction pipes at Beverley uranium mine, South Australia. 


\section{TERMITES, SOIL DEVELOPMENT AND MINERAL EXPLORATION (вох ${ }_{5.8)}$}

Termites and other ground-dwelling animals construct their nests from the regolith materials around them. These constructions have been used the world over by mineral explorers as a first-pass method of exploring the regolith to see what lies underneath. Most termites and ants build low, unremarkable mounds, but explorers in southern Africa have long recognised the ability of invertebrates to excavate material from beneath the surface cover and sort grains of different sizes. Where diamonds exist, diamond indicator minerals like garnet and pyroxene are often found in nests—and the odd diamond too!

In Australia, a number of termite species build remarkable, naturally air-conditioned nests'termitaria' - in areas of semi-arid and tropical/ subtropical savanna. These constructions can range from mounds to 'cathedrals' several metres tall and are built from material excavated from below ground as a colony grows. Analysis of the termitaria reveals that the termites access different parts of the regolith depending on the seasonal depth to the water-table, and build their termitaria in multiple lobes, which often express these different depth sources. Where transported cover hides relatively shallow bedrock, termites will burrow down to the bedrock interface to depths of tens of metres, presumably in search of water, and bring samples of saprolite back to the surface.

Termites, and other burrowing animals such as worms, are responsible for large-scale soil turnover and development, especially in warmer climates. Because of their large taxonomic diversity, Australian termites are thought to create larger biological modifications to the soil than in other arid areas of the world. In northern Queensland, burrowing animals, principally termites, have been shown by thermoluminescent age dating to turn over shallow soils (about $1 \mathrm{~m}$ thick) above basalt flows at remarkable rates, between $11 \mathrm{kyr}$ and $45 \mathrm{kyr}$. These ages indicate that it is possible for burrowing organisms to amalgamate and transport geochemical signals from a buried source, through a soil profile, in geologically short timeframes, certainly faster than ore pathfinder elements can be dissolved from primary minerals and removed by groundwater.

For mineral explorers, this is a boon, because the termites are doing the drilling for them. Termitaria in areas with shallow cover amalgamate the local geochemistry, including the bedrock, and may be sampled for geochemical analysis. The various particle size fractions contained within them express different $\mathrm{Au}$ and other mineral pathfinder elements and may be used to locate potential mineral resources under cover. In the Tanami Desert of northern Australia, termites have been shown to 'sample' Au-bearing saprolite from beneath $15 \mathrm{~m}$ of transported cover. In this area, the coarse, sandy fraction of the termitaria showed elevated levels of $\mathrm{Mo}$ and $\mathrm{Au}$, and the silty-clay fraction showed elevated levels of $\mathrm{Au}$, arsenic, $\mathrm{Zn}$ and $\mathrm{Ni}$, brought directly to the surface from the saprolite underneath. Thus, termitaria sampling can be used as a low-impact, inexpensive, culturally sensitive method of conducting a first-pass geochemical assay of a mineral tenement.

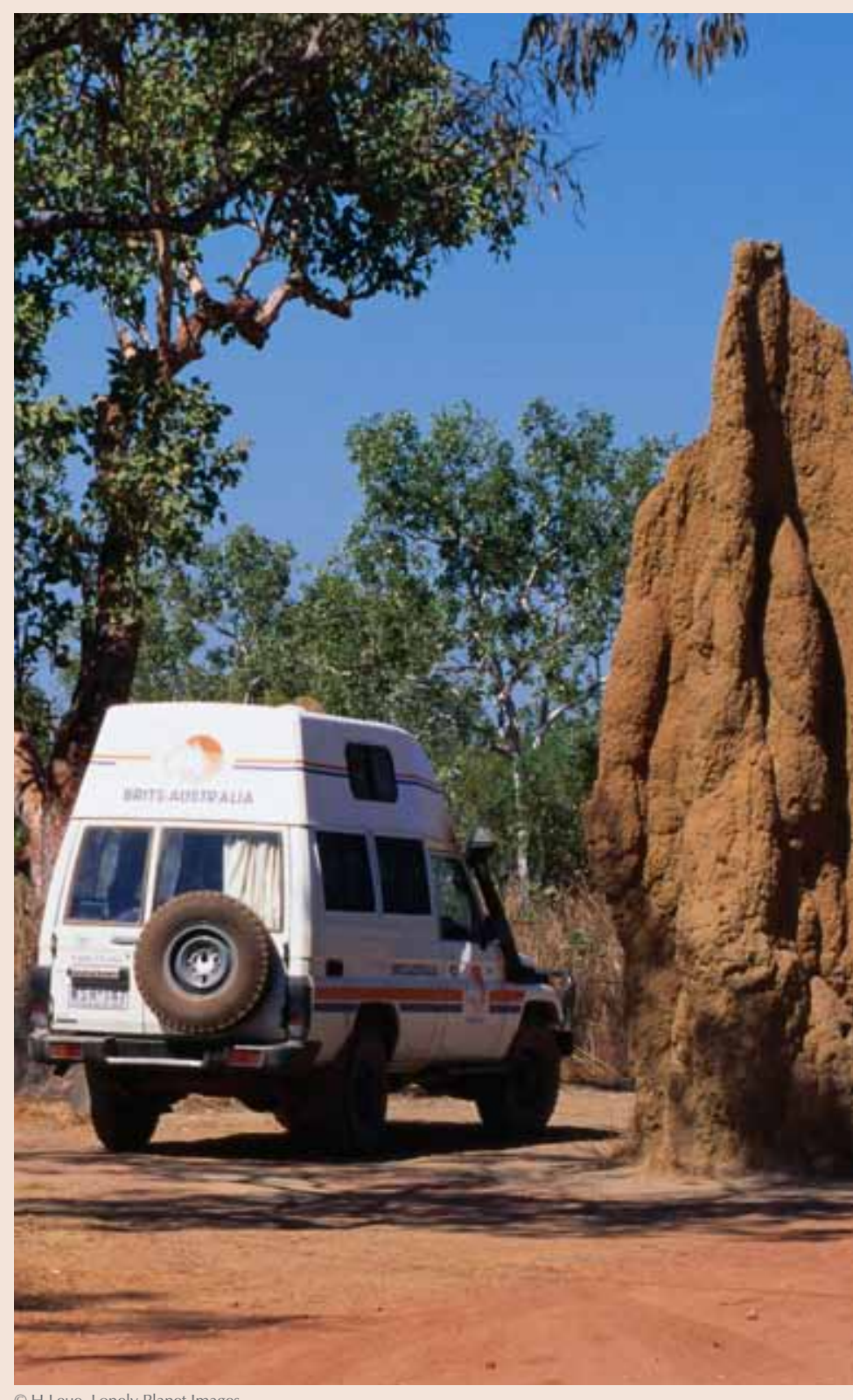

4WD bushcamper and cathedral termite mounds, Kakadu National Park, Northern Territory. 


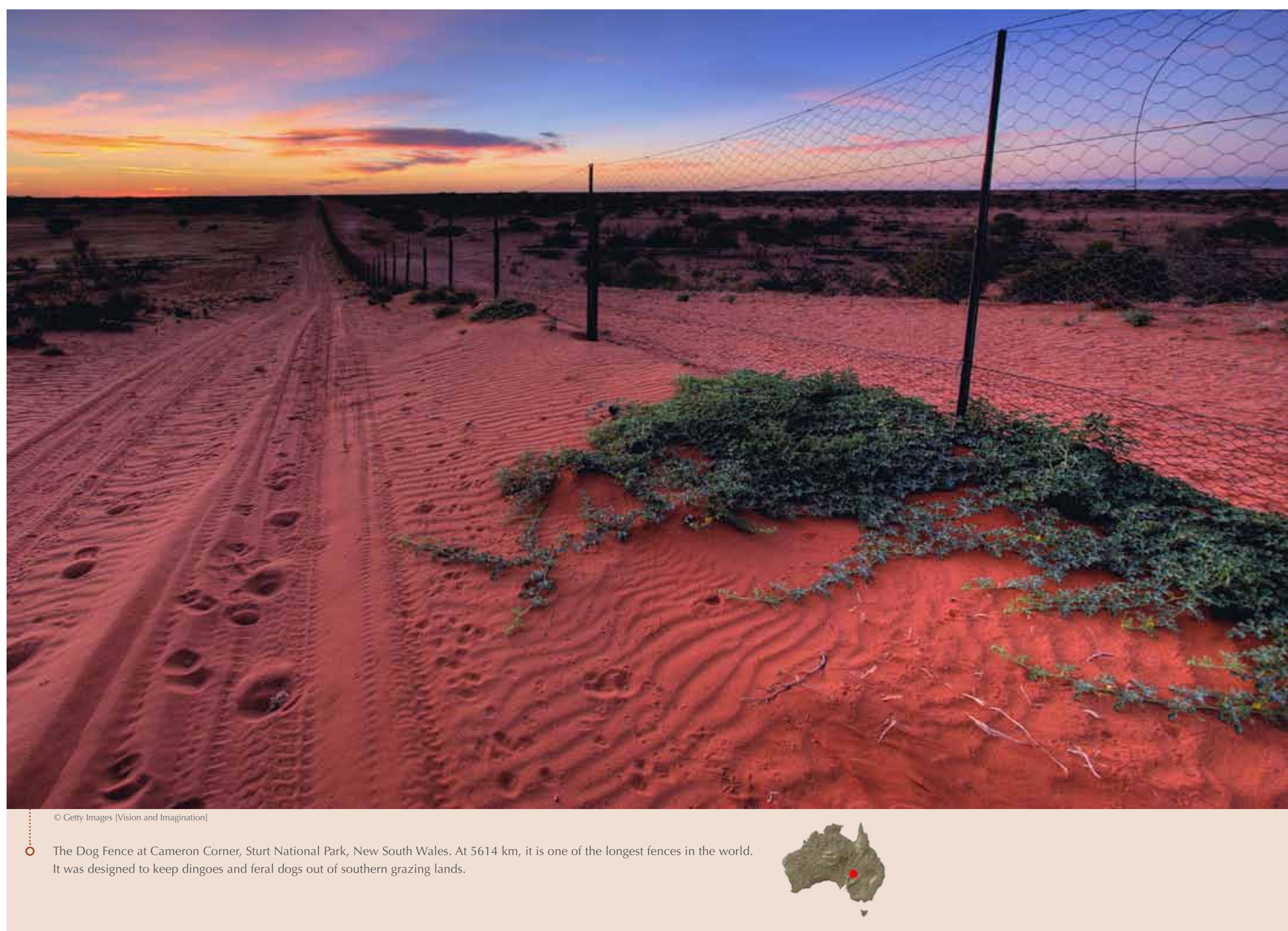


medium: calcrete commonly occurs over limestone as a weathering product (and therefore collected samples will be devoid of useful trace elements), and it is important to pay attention to the type of calcrete collected, and not mix groundwater (laminated) and pedogenic (nodular) calcrete samples, which is like comparing apples with oranges-they will have different background levels of metals.

\section{Bioprospecting}

Long recognised in northern Europe, Asia and North America, geobotany and biogeochemistry are now important exploration tools in Australia. Geobotany is the study of the relationship between plants and the geological conditions in which they occur, whereas biogeochemistry is the study of how plants express the chemistry of the geological substrate in which they grow.

A number of plants in Australia are now recognised as geobotanical indicators and grow only in chemically distinct (often metal-rich) soils: the widespread pearl bluebush (Maireana sedifolia) for regolith carbonate (calcrete); the copper weed (Polycarpaea spirostylis) in northern Queensland; the nickel bush (Stackhousia tryonii) in northern Queensland; the shrub violet (Hybanthus floribundus) in Western Australia for $\mathrm{Ni}$ and ultramafic rocks; and the thorny wattle (Acacia continua) for $\mathrm{Zn}$ at Broken Hill. Plant species suitable for biogeochemical sampling in search of minerals should be widespread and should accumulate or even hyperaccumulate (at orders of magnitude above background) ore metals or their pathfinder elements.
Animal activities can also provide a range of sampling media. Burrows provide soil samples from below the surface. These include the larger digging animals like wombats, but also the invertebrates like termites (Box 5.8). Sampling their diggings has proved to be a useful and inexpensive form of drilling. Herbivores eat plants, and their droppings can be analysed for the presence of anomalous metals. The scat of the western grey kangaroo, for example, has been successfully used to detect anomalous $U$ mineralisation in the sand-dune country of northeast Western Australia.

\section{Geophysical techniques}

Geophysics, especially airborne electromagnetics, has been adopted and improved by Australian scientists for imaging the regolith and what lies immediately beneath. The technique measures relative conductivity of regolith materials and can be used to assess their thickness and distribution. This has proven useful for mineral exploration-for example, to find unconformities and conductors (potential reductants), which are elements of basin-hosted $U$ mineral systems. The technique has also been adapted for research into regolith and groundwater salinity. In the latter case, with control provided by drilling data, airborne electromagnetics has been used to map the 3D distribution of aquifers and near-surface stratigraphic units. This, in turn, has allowed assessment of the likely impacts of irrigation and environmental water actions aimed at better use of water-for example, in the Murray River corridor through three states (Chapter 7).

\section{Plainly speaking}

In this chapter, we have explored the age and evolution of the landscape of the Australian continent and described how its age, and tectonic and climatic environments, have resulted in a flat landscape and a mainly deep regolith cover. The land has shaped the way people have settled and developed the continent, increasingly in the past 200 years. The mostly impoverished soils, a consequence of landscape age and stability, and the availability of water have restricted most settlement activity to the coastal belt. The nature of the regolith cover has been, and continues to be, of fundamental importance for water availability and for the successful discovery of minerals. People have also had an important impact on this ancient land, with soil loss, regulation of rivers, and irrigation with both surface water and groundwater. The first settlers, coming from wet tropical South-East Asia, had many thousands of years to adapt to the Australian environment; the last wave, coming from Europe, found the environment very different from the one they left behind. The Australian environment, so much a result of its underlying climate, geology, landforms and regolith, has presented a challenge to its settlers, one that by and large has been successfully met.

When you look at the map of Australia, you see the vast expanse of land, which is of course bounded by an extremely long coastline. We shall now show how the coast has shaped so many aspects of this nation. 
- Gibber plains near Chambers Gorge, Flinders Ranges, South Australia.

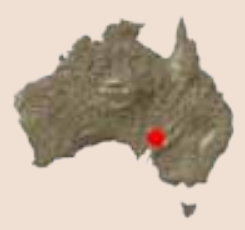

\section{Bibliography and further reading}

\section{Regolith}

Bishop P \& Pillans B (eds) 2010. Australian landscapes, Geological Society, London, Special Publication 346.

Cathcart M 2009. The water dreamers: the remarkable history of our dry continent, Text Publishing, Melbourne.

Cunningham C 1996. The Blue Mountains rediscovered: beyond the myths of early Australian exploration,

Kangaroo Press, Sydney.

Robin L 2007. How a continent created a nation, UNSW Press, Sydney.

Scott K \& Pain CF (eds) 2008. Regolith science, CSIRO Publishing, Melbourne.

Taylor G 1911. Australia in its physiographic and economic aspects, Oxford University Press, London.

Thorley P 2009. Desert tsunami: Australia's inland floods, from prehistory to present, Central Queensland University Press, Rockhampton.

\section{Cenozoic climate changes of the} Australian landscape

Bowler JM 1976. Aridity in Australia: age, origins and expression in aeolian landforms and sediments. Earth-Science Reviews 12, 279-310.

Bowler JM \& Magee JW 1978. Geomorphology of the Mallee region in semi-arid northern Victoria and western New South Wales. Proceedings of the Royal Society of Victoria $90,5-25$.

Bowler JM, Kotsonis A \& Lawrence CR 2006. Environmental evolution of the Mallee region, western Murray Basin. Proceedings of the Royal Society of Victoria 118 $116-210$

Dunkerley D 2010. Ecogeomorphology in the Australian drylands and the role of biota in mediating the effects of climate change on landscape processes and evolution. In:Australian landscapes, Bishop P \& Pillans B (eds), Geological Society, London, Special Publication 346, $87-120$.

Fujioka T \& Chappell J 2010. History of Australian aridity: chronology in the evolution of arid landscapes. In: Australian landscapes, Bishop P \& Pillans B (eds), Geological Society, London, Special Publication 346, 121-139.

Jennings JN 1968. A revised map of the desert dunes of Australia. The Australian Geographer 10, 408-409.

McLaren S, Wallace MW, Gallagher SJ, Miranda JA, Holdgate GR, Gow LJ, Snowball I \& Sandgren P 2011. Palaeogeographic, climatic and tectonic change in southeastern Australia: the Late Neogene evolution of the Murray Basin. Quaternary Science Reviews 30, 1086-1111.

Pillans B 2007. Pre-Quaternary landscape inheritance in Australia. Journal of Quaternary Science 22, 439-447.

\section{Why so flat?}

Belton DX, Brown RW, Kohn BP, Fink D \& Farley KA 2004. Quantitative resolution of the debate over antiquity of the central Australian landscape: implications for the tectonic and geomorphic stability of cratonic interiors. Earth and Planetary Science Letters 219, 21-34.

Braun J, Burbidge DR, Gesto FN, Sandiford M, Gleadow AJW, Kohn BP \& Cummins PR 2009. Constraints on the current rate of deformation and surface uplift of the Australian continent from a new seismic database and low-T thermochronological data. Australian Journal of Earth Sciences 56, 99-110.

Clark D, McPherson A \& Collins C 2011. Australia's seismogenic neotectonic record: a case for heterogeneous intraplate deformation, Geoscience Australia Record 2011/11, Geoscience Australia, Canberr

Gallagher K, Dumitru TA \& Gleadow AJW 1994. Constraints on the vertical motion of eastern Australia during the Mesozoic. Basin Research 6, 77-94.

Hesse PP 1994. The record of continental dust from Australia in Tasman Sea sediments. Quaternary Science Reviews 13, 257-272.

Hesse PP, Humphreys GS, Smith BL, Campbell J \& Peterson EK 2003. Age of loess deposits in the Central Tablelands of New South Wales. Australian Journal of Soil Research 41 , $1115-1131$

Hill SM 1999. Mesozoic regolith and palaeo-landscape features in southeastern Australia: significance for interpretations of denudation and highland evolution. Australian Journal of Earth Sciences 46, 217-232. 
Hou B, Frakes LA, Sandiford M, Worrall L, Keeling J $\&$ Alley NF 2008. Cenozoic Eucla Basin and associated palaeovalleys, southern Australia—climatic and tectonic influences on landscape evolution, sedimentation and heavy mineral accumulation. Sedimentary Geology 203, 112-130.

Jutson JT 1914. An outline of the physiographical geology (physiography) of Western Australia, Geological Survey of Western Australia Bulletin 61.

Knighton AD \& Nanson GC 2000. Waterhole form and process in the anastomosing channel system of Cooper Creek, Australia. Geomorphology 35, 101-117.

Nott JF 1992. Long-term drainage evolution in the Shoalhaven catchment, southeast highlands, Australia. Earth Surface Processes and Landforms 17, 361-374.

Ollier CD 1982. The Great Escarpment of Eastern Australia: tectonic and geomorphic significance. Journal of the Geological Society of Australia 29, 13-23.

Ollier CD 2001. Evolution of the Australian landscape. Marine and Freshwater Research 52, 13-23.

Pain CF 1985. Morphotectonics of the continental margins of Australia. Zeitschrift für Geomorphologie supplement band 54, 23-35.

Quigley MC, Clark D \& Sandiford M 2010. Tectonic geomorphology of Australia. In: Australian landscapes, Bishop P \& Pillans B (eds), Geological Society, London, Special Publication 346, 243-265.

Sandiford M 2007. The tilting continent: a new constraint on the dynamic topographic field from Australia. Earth and Planetary Science Letters 261, 152-163.

Tooth S \& Nanson GC 2000. The role of vegetation in the formation of anabranching channels in an ephemeral river,

Northern plains, arid central Australia. Hydrological Processes 14, 3099-3117.

Twidale CR 1991. A model of landscape evolution involving increased and increasing relief amplitude. Zeitschrift für Geomorphologie 35, 85-109.

Twidale CR 1994. Gondwanan (Late Jurassic and Cretaceous) palaeosurfaces of the Australian Craton. Palaeogeography, Palaeoclimatology, Palaeoecology 112, 157-186.

Twidale CR 2000. Early Mesozoic (?Triassic) landscapes in Australia: evidence, argument, and implications. Journal of Geology 108, 537-552.
Woolnough WG 1927. Presidential address: part I-the chemical criteria of peneplanation, part II-the duricrust of Australia. Journal and Proceedings of the Royal Society of NSW 61, 1-53.

\section{Regolith-everything between fresh rock and fresh air}

Eggleton RA (ed.) 2001. The regolith glossary: surficial geology, soils and landscape, Cooperative Research Centre for Landscape Environments and Mineral Exploration, Canberra and Perth.

Ollier CD \& Pain CF 1996. Regolith, soils and landforms, John Wiley and Sons Ltd, Chichester.

Taylor G \& Eggleton RA 2001. Regolith geology and geomorphology, John Wiley and Sons, Chichester.

Taylor G, Eggleton RA, Foster LD \& Morgan CM 2008. Landscapes and regolith of Weipa, northern Australia. Australian Journal of Earth Sciences 55(S1), S3-S16.

Wilford JR (in press). A weathering intensity index for the Australian continent using airborne gamma-ray spectrometry and digital terrain analysis. Geoderma.

Wilson MJ 2004. Weathering of the primary rock-forming minerals: processes, products and rates. Clay Minerals 39, 233-266.

\section{How old is the Australian landscape?}

Killick M 1998. Phanerozoic denudation of the Western Shield of Western Australia. Geological Society of Australia Abstracts 49, 248

Kohn BP, Gleadow AJW, Brown RW, Gallagher K,

O'Sullivan PB \& Foster DA 2002. Shaping the Australian crust over the last 300 million years: insights from fission track thermotectonic imaging and denudation studies of key terranes. Australian Journal of Earth Sciences 49, 697-717.

Osborne RAL, Zwingmann H, Pogson RE \& Colchester DM 2006. Carboniferous clay deposits from Jenolan Caves, New South Wales: implications for timing of speleogenesis and regional geology. Australian Journal of Earth Sciences 53 , 377-405.

Pillans B 1997. Soil development at a snail's pace: evidence rom a 6 Ma soil chronosequence on basalt in north Queensland, Australia. Geoderma 80, 117-128.
Stewart AJ, Blake DH \& Ollier CD 1986. Cambrian river terraces and ridgetops in central Australia: oldest persisting landforms? Science 233, 758-761.

\section{How regolith enriches Australia}

Anand RR \& Paine M 2002. Regolith geology of the Yilgarn Craton, Western Australia: implications for exploration. Australian Journal of Earth Sciences 49, 3-162.

Britt AF, Smith RE \& Gray DJ 2001. Element mobilities and the Australian regolith - a mineral exploration perspective. Marine and Freshwater Research 52, 25-39.

Connolly MJ 2012. Munda-gutta Kulliwari, Dreamtime Kullilla-Art. www.dreamtime.auz.net

Eggleton RA, Taylor G, Le Gleuher M, Foster LD, Tilley DB \& Morgan CM 2008. Regolith profile, mineralogy and geochemistry of the Weipa Bauxite, northern Australia Australian Journal of Earth Sciences 55(S1), S17-S43.

Government of South Australia 2010. Geology of the McLaren Vale wine region, Primary Industries and Resource South Australia, Adelaide.

Kotsonis A 1999. Tertiary shorelines of the western Murray Basin: weathering, sedimentology and exploration potential. In: Extended abstracts of Murray Basin Mineral Sands Conference, Mildura, Victoria, 21-23 April, 57-63.

McNally GH 1995. Engineering characteristics and uses of duricrusts in Australia. Australian Journal of Earth Sciences 42, 535-547.

Petts AE, Hill SM \& Worrall L 2009. Termite species variation and their importance for termitaria biogeochemistry: toward a robust media approach for mineral exploration. Geochemistry: Exploration, Environment, Analysis 9, 257-266.

Pillans B, Spooner D \& Chappell J 2002. The dynamics of soils in north Queensland: rates of mixing by termites determined by single grain luminescence dating. In: Regolith and landscapes in eastern Australia, Roach IC (ed.), Cooperative Research Centre for Landscape Environments and Mineral Exploration, Canberra and Perth, 100-101.

Senior BR, McColl DH, Long BE \& Whitely RJ 1977. The geology and magnetic characteristics of precious opal deposits, southwest Queensland. BMR Journal of Australian Geology and Geophysics 2, 241-251.

Taylor G \& Eggleton RA 2008. Genesis of pisoliths and of the Weipa Bauxite deposit, northern Australia. Australian Journal of Earth Sciences 55(S1), S87-S103. 